\title{
PADRÃO ALIMENTAR E ESTADO NUTRICIONAL: CARACTERIZAÇÃO DE ESCOLARES DE MUNICÍPIO PAULISTA
}

\author{
VANESSA MAESTRO
}

Dissertação apresentada à Escola Superior de Agricultura "Luiz de Queiroz", Universidade de São Paulo, para obtenção do título de Mestre em Ciências, Área de Concentração: Ciência e Tecnologia de Alimentos.

\author{
PIRACICABA \\ Estado de São Paulo - Brasil
}

Novembro - 2002 


\title{
PADRÃO ALIMENTAR E ESTADO NUTRICIONAL: CARACTERIZAÇÃO DE ESCOLARES DE MUNICÍPIO PAULISTA
}

\author{
VANESSA MAESTRO
}

Nutricionista

Orientadora: Profa. Dra. MARINA VIEIRA DA SILVA

Dissertação apresentada à Escola Superior de Agricultura "Luiz de Queiroz", Universidade de São Paulo, para obtenção do título de Mestre em Ciências, Área de Concentração: Ciência e Tecnologia de Alimentos.

\author{
PIRACICABA \\ Estado de São Paulo - Brasil \\ Novembro - 2002
}


Dados Internacionais de Catalogação na Publicação (CIP) DIVISÃO DE BIBLIOTECA E DOCUMENTAÇÃO - ESALQ/USP

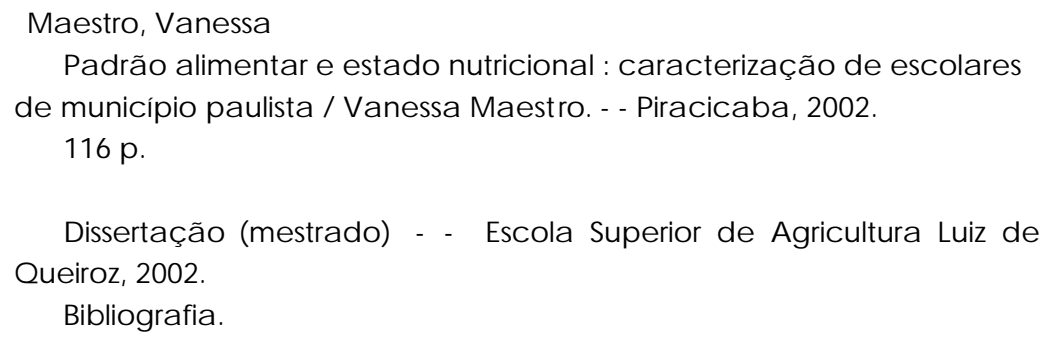

1. Análise sóc io-ec onômic a 2. Consumo de alimentos 3. Escola pública 4. Estu-dantes 5. Nutrição humana 6. Qualidade de vida 7. Saúde Pública I. Título

CDD 612.3 
Dedico este trabalho:

aos meus pais Geraldo e Lucia, pelo constante apoio em todos os momentos e pelos sábios conselhos.

ao meu namorado Nelson, por ser uma pessoa maravilhosa que sempre demonstrou muita compreensão, carinho, paciência e companheirismo, durante toda a minha caminhada. 


\section{AGRADECIMENTOS}

À Profa. Dra. Marina Vieira da Silva, pelos valiosos ensinamentos e pela constante dedicação e amizade.

À Banca do Exame de Qualificação: Profa. Dra. Denise Giácomo da Motta, Profa. Dra. Marília Oetterer e Profa. Dra. Marta Helena Fillet Spoto, pela contribuição ao trabalho.

Ao Prof. Dr. Rodolfo Hoffmann, pelo auxílio na elaboração das análises estatísticas.

Às amigas Priscila Brigide, Michele Sanches e Daniela Cristina Rossetto Caroba por todo o apoio e incentivo nos momentos necessários.

À Vilma Aparecida Sarto Zeferino, funcionária do serviço de comutação bibliográfica da ESALQ, pela prontidão e simpatia.

Às bibliotecárias Beatriz Helena Giongo, Midian Gustinelli e Ligiana Clemente do Carmo, pela atenção no atendimento e pela contribuição na revisão do trabalho.

À Prefeitura Municipal de Piedade, à Secretaria Municipal de Educação e à Direção e Funcionários das escolas integrantes da pesquisa, pelo consentimento àrealização desta pesquisa.

À todos os escolares e seus familiares que participaram da pesquisa, pela importante cooperação durante a etapa de coleta de dados.

Ao Conselho Nacional de Desenvolvimento Científico e Tecnológico pela concessão da bolsa de Mestrado e à Fundação de Amparo à Pesquisa do Estado de São Paulo pela concessão da bolsa de Treinamento Técnico. 


\section{SUMÁRIO}

Página

LISTA DE QUADROS........................................................................ vii

LISTA DE TABELAS....................................................................... viii

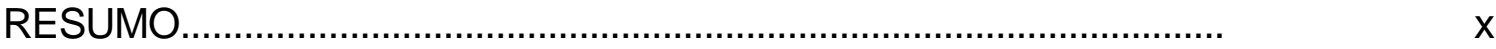

SUMMARY ...................................................................................

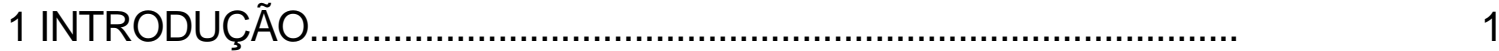

2 REVISÃO DE LITERATURA..............................................................

2.1 Estado nutricional......................................................................

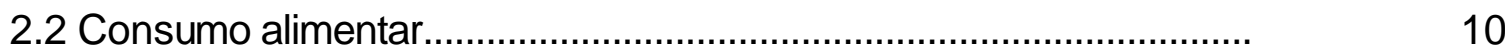

2.2.1 Alimentos in natura e industrializados...........................................

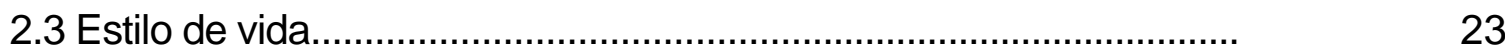

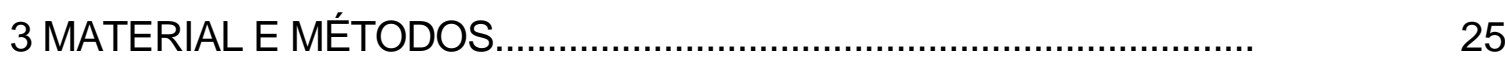

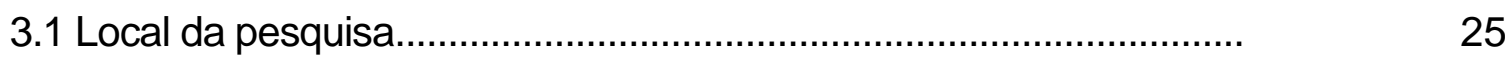

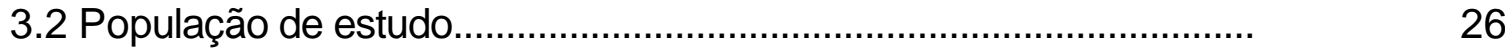

3.3 Delineamento da pesquisa............................................................ 29

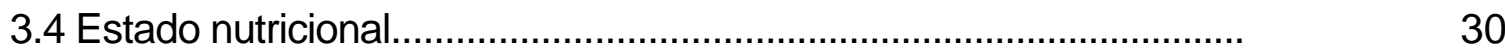

3.5 Consumo de alimentos e estilo de vida............................................... 32

3.6 Informações socioeconômicas da família............................................ 36

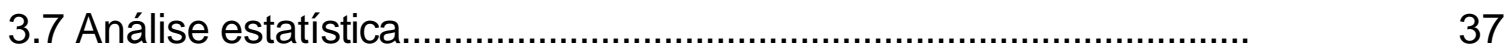

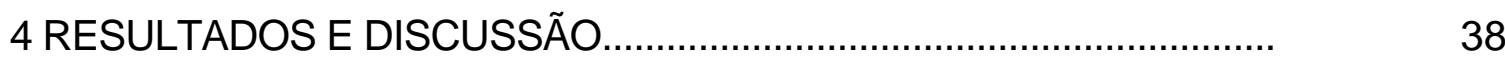

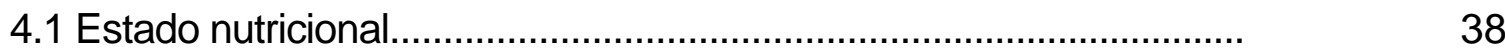


4.2 Consumo alimentar....................................................................

4.2.1 Análises qualitativas............................................................. 44

4.2.2 Análises quantitativas................................................................

4.3 Estilo de vida...........................................................................

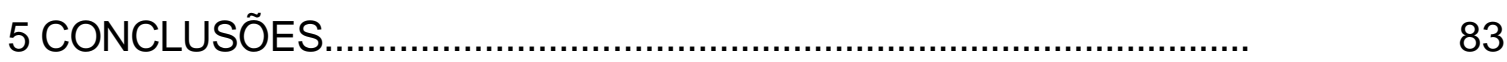

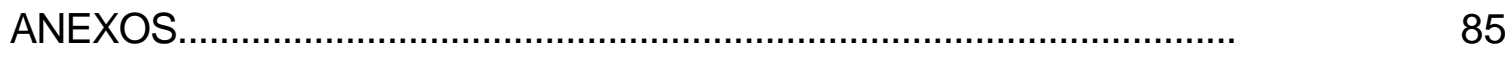

REFERÊNCIAS BIBLIOGRÁFICAS ................................................. 100 


\section{LISTA DE QUADROS}

Página

1 Recomendações de energia e nutrientes de acordo com a idade (em anos) dos escolares do sexo masculino......................................

2 Recomendações de energia e nutrientes de acordo com a idade (em anos) dos escolares do sexo feminino....................................... 


\section{LISTA DE TABELAS}

Página

1 Distribuição das escolas de acordo com os estratos e o número de alunos matriculados. Piedade - SP, 2000

2 Unidades escolares que integram a amostra da pesquisa. Piedade SP, 2000.

3 Distribuição dos alunos integrantes da pesquisa, de acordo com o estrato. Piedade - SP, 2000

4 Distribuição dos escolares de acordo com a faixa de idade e sexo. Piedade - SP, 2000.

5 Distribuição dos escolares em três categorias do estado nutricional, com base no escore $Z$ de altura para idade, de acordo com a unidade de ensino de origem. Piedade - SP, 2000

6 Distribuição dos escolares com base no Índice de Massa CorporalIMC e estratos de renda familiar per capita. Piedade - SP, 2000.......

7 Distribuição dos escolares com base no Índice de Massa Corporal IMC e a atividade profissional da mãe. Piedade - SP, 2000..............

8 Distribuição dos escolares com base no Índice de Massa Corporal IMC e o costume de consumir alimentos fora de casa. Piedade SP, 2000

9 Freqüência de citações dos alimentos. Piedade - SP, 2000. 
10 Distribuição dos escolares de acordo com o sexo e a participação relativa dos grupos de alimentos, no consumo total de alimentos Piedade - SP, 2000.

11 Distribuição dos percentis do consumo de energia e nutrientes selecionados dos escolares. Piedade - SP, 2000.

12 Distribuição dos percentis de consumo de energia e nutrientes selecionados, de acordo com o sexo dos escolares. Piedade - SP, 2000

13 Distribuição dos escolares de acordo com a participação dos macronutrientes na dieta e o sexo. Piedade - SP, 2000.....................

14 Distribuição dos escolares de acordo com a participação dos macronutrientes na dieta e estratos de idade (em anos). Piedade SP, 2000

15 Distribuição dos escolares de acordo com estratos de idade e sexo e participação relativa dos alimentos in natura e industrializados na

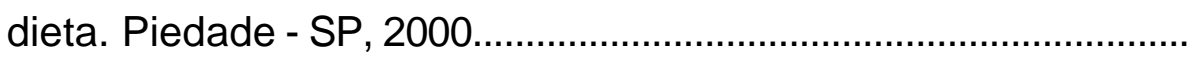




\title{
PADRÃO ALIMENTAR E ESTADO NUTRICIONAL: CARACTERIZAÇÃO DE ESCOLARES DE MUNICÍPIO PAULISTA
}

\author{
Autora: VANESSA MAESTRO \\ Orientadora: Profa. Dra. MARINA VIEIRA DA SILVA
}

\section{RESUMO}

A literatura especializada tem registrado, com ênfase, que a alimentação tem função primordial para 0 atendimento das necessidades energéticas $\mathrm{e}$ nutricionais das crianças e adolescentes e, ainda, exercem papel fundamental para a prevenção de doenças na fase adulta. $O$ consumo freqüente de dietas inadequadas, aliadas muitas vezes ao sedentarismo, podem comprometer 0 estado nutricional dos escolares. A conscientização das crianças e adolescentes para um estilo de vida mais saudável faz-se necessária, contribuindo para a promoção e consolidação de hábitos saudáveis. Face ao exposto, julgou-se pertinente analisar a situação da população jovem, que vive em município cuja população ocupa, predominantemente, a área rural. Para tanto, foi definida amostra $(n=508)$ representativa dos alunos da rede pública de ensino de Piedade, São Paulo, com vistas a conhecer o estado nutricional e alguns de seus condicionantes, o consumo alimentar e o estilo de vida dos alunos amostrados, com idade entre 6 e 18 anos. Foram analisados os indicadores antropométricos (escore Z de altura para idade - ZAl) e a distribuição do Índice 
de Massa Corporal - IMC. Os dados sobre o consumo alimentar e estilo de vida dos escolares foram obtidos por meio de um questionário. Também utilizando-se questionários específicos identificou-se as condições socioeconômicas das famílias. Entre os principais resultados, vale ressaltar que apenas 3\% dos escolares apresentaram ZAI < -2 (indicativo de déficit de altura). Observou-se $13,4 \%$ dos escolares com IMC $\geq 85^{\circ} \mathrm{P}$. Verificou-se forte associação entre o IMC dos escolares e o trabalho da mãe fora de casa. Entre os alimentos mais citados nas dietas dos escolares destacam-se: arroz, pão, feijão, hortaliças, leite, carne bovina, café, margarina e achocolatado em pó. Merece destaque a baixa ingestão, entre os escolares, de energia, fibras, folacina, vitamina $C$, vitamina $A$, vitamina $E$, cálcio, ferro e zinco. Foi observado consumo considerado elevado de proteínas, vitamina $B_{12}$ e selênio. $A$ análise da participação dos macronutrientes no valor energético total revelou que cerca de $65 \%$ dos alunos apresentaram dietas inadequadas, não tendo sido observadas diferenças expressivas quando se analisou os resultados discriminando o grupo, de acordo com o sexo. Quando se analisou os resultados, tendo por base as dietas dos alunos classificados de acordo com a idade, maior proporção $(66,2 \%)$ de dietas inadequadas foi observada entre o grupo mais jovem (com idade inferior a 10 anos). Verificou-se que os escolares permanecem em média 3,3 horas diárias expostos à programação televisiva. O estado nutricional da população pode ser classificado como satisfatório, mas em relação ao consumo de alimentos, faz-se necessário a intervenção com vistas, por exemplo, à reeducação alimentar, a fim de oferecer subsídios aos escolares para a adoção de práticas alimentares benéficas àsaúde. 


\title{
ALIMENTARY STANDARD AND NUTRITIONAL STATUS: CHARACTERIZATION OF STUDENTS FROM A MUNICIPAL DISTRICT IN SÃo PAULO STATE
}

\author{
Autora: VANESSA MAESTRO \\ Orientadora: Profa. Dra. MARINA VIEIRA DA SILVA
}

\section{SUMMARY}

The specialized literature has registered, with emphasis, that the feeding has primordial function in supplying children and teenagers energy and nutritional needs and, still, they have a fundamental role for the prevention of diseases in the adult phase. The frequent consumption of inadequate diets, allied to inactiveness, may put under risk students nutritional status. Children and teenagers awareness for a healthier lifestyle has become necessary, contributing to the promotion and consolidation of healthy habits. Therefore, the analysis of the situation of the young population was considered pertinent, once they live in a municipal district which population is located, predominantly, in the rural area. This way, a representative sample of students from the public teaching net of Piedade, São Paulo, was defined $(n=508)$, aiming to know the nutritional status and some of their restrictions, the alimentary consumption and the lifestyle of the sampled students, between 6 and 18 years old. The anthropometrical indicators were analyzed (Z-score of height-for-age - ZAI) and the distribution of the Index 
of Body Mass Index - BMI. The information on the alimentary consumption and the students' lifestyle were obtained through a questionnaire. Also through specific questionnaires the socioeconomic conditions of the families were identified. Among the main results, it is worth to emphasize that only $3 \%$ of the students presented ZAI $<-2$ (indicative of height deficit). It was observed that $13,4 \%$ of the students with $I M C \geq 85^{\circ} \mathrm{P}$. A strong association was verified between the students' BMI and the fact of having the mother' working out of home. Among the most mentioned foods in the students' diets we can stand out: rice, bread, bean, vegetables, milk, bovine meat, coffee, margarine and powdered chocolate. We have to highlight and turn attention to the low ingestion, among the students, of energy, fibers, folacin, vitamin $C$, vitamin $A$, vitamin $E$, calcium, iron and zinc. A high consumption of proteins, vitamin B12 and selenium was observed. The analysis of the participation of the macronutrients in the total energy value revealed that about $65 \%$ of the students presented inadequate diets, not having been observed expressive differences when analyzed the results discriminating the group, concerning gender. When the results were analyzed, based on students' diets classified concerning age, a larger proportion $(66,2 \%)$ of inadequate diets was observed among the youngest group (10 years old or less). It was verified that the students spend an average of 3,3 hours daily in front of television. The nutritional status of the population can be classified as satisfactory, but concerning the consumption of foods, it is necessary an intervention aiming, for instance, an alimentary reeducation, in order to offer subsidies to the students to adopt beneficial alimentary practices to the health. 


\section{INTRODUÇÃO}

A alimentação cumpre um papel primordial durante todo o ciclo de vida dos indivíduos. Entre as distintas fases da vida, pode-se destacar, como exemplo, a idade escolar que se caracteriza por ser um período em que a criança apresenta um metabolismo muito mais intenso quando comparado com o do adulto e com freqüência apresenta, também, intensa atividade corporal e mental. Para atender à elevada demanda de energia e de nutrientes o referido grupo de indivíduos necessita consumir grande diversidade e quantidade de alimentos (Philippi et al., 2000).

Trata-se, portanto, de um período em que o crescimento dos indivíduos deve ser adequado, pois seu comprometimento pode resultar em conseqüências como aumento da prevalência da morbidade, aprendizado deficiente e a longo prazo, possivelmente adultos com menor capacidade física e mental (Philippi et al., 2000).

Vale lembrar também que a adolescência (fase considerada decisiva do crescimento e desenvolvimento humano) é identificada como sendo o período de transição entre a infância e a idade adulta com marcantes transformações anatômicas, fisiológicas, mentais e sociais. Compreende, segundo critério cronológico, o período que se inicia entre 10 e 12 anos de idade e é concluído ao redor dos 20 anos (Colli \& Deluqui, 1978).

Em relação aos hábitos alimentares, é importante frisar que estes são praticamente consolidados na infância e tendem a permanecer ao longo da vida. Os fatores fisiológicos, sócio-culturais e psicológicos influenciam na formação 
dos hábitos alimentares, além destes serem condicionados, em parte, pela disponibilidade de alimentos (Morgan et al., 1981).

A família, na maioria das sociedades, ainda é o principal grupamento responsável pela formação e consolidação de parcela substancial dos hábitos alimentares das crianças, com menor idade, pois são os pais (e com maior freqüência as mães) os responsáveis pela compra e preparo dos alimentos (Gambardella et al., 1999).

Ruffo (1997) registrou que a família é o primeiro grupo de referência também para os adolescentes quando se trata da alimentação. No entanto, os amigos exercerão papel decisivo na consolidação do hábito alimentar do adolescente. Os adolescentes, pela necessidade de serem aceitos nos grupos sociais, podem adotar hábitos alimentares inadequados como por exemplo, a ingestão excessiva de sanduíches e até a escolha de dietas restritivas.

Silva \& Rego (2000) apontam características dos hábitos alimentares dos adolescentes, destacando: maior tendência para omitir refeições, principalmente o café da manhã e o almoço; maior consumo de lanches e doces, especialmente dos alimentos comercializados em estabelecimentos do tipo fast food; adoção de dietas de emagrecimento; maior consumo de refrigerantes, café, chá e bebidas alcoólicas, freqüentemente substituindo o consumo de leite e sucos; maior independência para aquisição e preparo dos alimentos para si mesmos.

Pesquisa desenvolvida pelo Instituto Sodexho, tendo por base dados obtidos em 11 países (Bélgica, Canadá, França, Alemanha, Itália, Holanda, Espanha, Inglaterra, Estados Unidos, Suécia e Brasil), envolvendo indivíduos de ambos os sexos, com idade entre 5 a 17 anos, mostrou que os meninos gastam três vezes mais com alimentação fora do domicílio do que as meninas, sendo que no Brasil, chegam a gastar cinco vezes mais que as meninas. Este fato provavelmente deve estar relacionado com o fato das meninas, integrantes da amostra da pesquisa, associarem o prazer de comer com a necessidade de manter a saúde e a boa forma, enquanto os meninos associam o sabor da comida como um dos aspectos mais importantes do ritual social da alimentação. 
Em relação ao tempo gasto nas refeições, a pesquisa apontou que as meninas dedicam $50 \%$ mais tempo, quando se considera as refeições matinais e os meninos reservam $62 \%$ mais tempo às refeições do tipo almoço e jantar. Outro fato interessante, registrado pela referida pesquisa, é a análise quantitativa do consumo. Foi possível observar que, em média, os meninos consomem 3,3 itens por refeição, enquanto as meninas, 2,1. A diferença tende aumentar conforme a idade do grupo também cresce. Quanto ao tipo de alimento, as meninas consomem duas vezes mais frutas, vegetais e laticínios, enquanto os meninos optam por pratos mais elaborados, com o consumo de carne e carboidrato três e cinco vezes maiores, respectivamente (Martins Filho, 2001).

Especificamente quanto à importância da educação nutricional dirigida æ̀ crianças e jovens, Vannucchi et al. (1990) salientaram que a orientação para a formação de adequados hábitos alimentares deve ser, em parte, assumida pelo sistema de saúde e educacional e, também, com o envolvimento dos meios de comunicação.

Com relação àimportância da adoção de práticas alimentares adequadas, como valioso recurso para a manutenção da qualidade de vida e prevenção de doenças crônicas e obesidade, Anderson (1991) destacou que a maioria dos adolescentes não revela preocupação com as conseqüências futuras de seus hábitos alimentares, muitas vezes inadequados. Há valorização, invariavelmente, pelos adolescentes somente do momento atual.

Neste sentido, Ruffo (1997) também salientou que os adolescentes têm dificuldade na introjeção de um comportamento nutricional preventivo, que envolva a decisão de ingerir alimentos de forma adequada para dispor de boa saúde no futuro. A razão para tal comportamento é que na adolescência alguns conceitos como tempo futuro e implicações dos atos do presente não são bem compreendidas. Ainda, de acordo com o mesmo autor, quanto mais precocemente as crianças incorporarem hábitos que condicionem "erros alimentares", com maior probabilidade, mais cedo, surgirão as doenças deles resultantes. 
Alguns autores como Mondini \& Monteiro (1995) ${ }^{*}$ registraram que as informações sobre consumo alimentar, principalmente entre o grupamento infantil, são escassas em nosso meio. Também são poucas as informações de como as mudanças nos padrões dietéticos ocorreram e influenciaram a prevalência da desnutrição e da obesidade (problemas mais freqüentes em saúde pública e que caminham juntos). De acordo com os autores, mesmo dispondo de poucos levantamentos com abrangência nacional, foi possível verificar que o consumo relativo de gorduras (ocorrido em 1988) na Região Sudeste $(30,8 \%)$, ultrapassou o limite máximo (15-30\%) recomendado pela Organização Mundial de Saúde - OMS. Outra constatação que mereceu destaque foi o consumo excessivo de açúcar observado e o consumo insuficiente de carboidratos complexos. Mondini \& Monteiro (1995) destacaram um aspecto positivo relativo à qualidade da gordura consumida pela população brasileira, ou seja, nas últimas décadas foi observado um claro aumento do consumo de ácidos graxos poliinsaturados, em detrimento do consumo de ácidos graxos saturados.

Considerando a importância da realização de estudos de consumo alimentar no Brasil, em 1996 o Instituto Nacional de Alimentação e Nutrição (INAN) realizou, em conjunto com universidades brasileiras, uma ampla pesquisa denominada "Estudo Multicêntrico sobre Consumo de Alimentos". O consumo de alimentos, pela população, foi avaliado em cinco cidades do Brasil: Campinas, Curitiba, Goiânia, Ouro Preto e Rio de Janeiro. Foi possível comprovar, mais uma vez, que o arroz e o feijão (alimentos até então tradicionais da culinária brasileira) não estavam presentes, de maneira tão freqüente, nas principais refeições da população, pois seu consumo diminuiu cerca de $30 \%$ nos últimos 20 anos (Bleil, 1998).

\footnotetext{
* Ainda hoje, no país, a mais completa fonte de dados com enfoque no consumo alimentar data de 1974/75. Trata-se do Estudo Nacional sobre Despesa Familiar-ENDEF, realizado pelo Instituto Brasileiro de Geografia e Estatística-IBGE. O estudo envolve uma amostra probabilística de 55.000 domicílios de todo o país. O método utilizado foi pesagem direta por 4 dias consecutivos em cada domicílio.
} 
Análises elaboradas recentemente por Monteiro et al. (2000) revelaram que a participação relativa de açúcar refinado e refrigerantes também cresceu entre todas as famílias das regiões metropolitanas do país.

Com base no exposto, nota-se que nos últimos anos houve um crescimento substancial do consumo de alimentos industrializados, com diferentes graus de processamento. É possível constatar que há escassez de informações sobre a participação dos alimentos industrializados no consumo alimentar de crianças e jovens, especialmente quando se considera a população moradora de municípios com substancial concentração de habitantes na zona rural.

Castro \& Magalhães (1998), ao analisarem a evolução da estrutura do gasto familiar, tendo como base os dados das Pesquisas de Orçamentos Familiares - POFS, dos anos de 1987/88 e 1995/96, mostraram uma redução da participação dos gastos com alimentação para o total das áreas pesquisadas, e para o conjunto das famílias, de $25,3 \%$ para $23,6 \%$ entre os anos de $87 / 88$ e 95/96. Os autores destacam que, entretanto, quando se considera as famílias mais pobre de Fortaleza, por exemplo, cerca de $49,2 \%$ dos gastos com consumo eram destinados aos alimentos, ou seja, praticamente metade das despesas de consumo das famílias estavam comprometidas com alimentação. Quando se examina as informações para a região metropolitana de São Paulo, uma família pertencente ao menor estrato de renda, destina $32,4 \%$ do seu gasto de consumo com o alimentos.

Carvalho et al. (2001) enfatizam a importância da identificação precoce de práticas alimentares inadequadas a fim de que medidas corretivas, dirigidas especialmente aos escolares, sejam adotadas para a obtenção de dietas que atendam as necessidades nutricionais dos mesmos, favorecendo a prevenção de doenças, especialmente as crônicas.

Visando preencher a lacuna ainda existente de informações sobre a situação nutricional de indivíduos, principalmente em idade escolar, 
implementou-se pesquisa entre alunos do município de Piedade, Estado de São Paulo, tendo como objetivos:

- descrever o estado nutricional de escolares e alguns de seus principais condicionantes;

- analisar o consumo alimentar dos escolares;

- conhecer a proporção dos gastos com alimentação, em relação aos rendimentos familiares. 


\section{REVISÃO DE LITERATURA}

\subsection{Estado nutricional}

Pesquisas relativas ao estado nutricional das populações de países ricos e também de regiões menos desenvolvidas têm revelado a redução da incidência das doenças infecto-contagiosas e a elevação da incidência de doenças crônico-degenerativas (Gamba \& Barros Júnior, 1999).

Os estudos epidemiológicos envolvendo, especificamente, a determinação da situação da obesidade infantil são ainda muito escassos e geralmente restritos à população dos países desenvolvidos. O contínuo crescimento da obesidade em adultos registrado em diversos países, incluindo o Brasil, aponta para a necessidade da monitoração dos indicadores da obesidade em outros grupos etários, como os compostos por crianças e adolescentes (Monteiro \& Conde, 2000).

Segundo Silva \& Rego (2000) é freqüentemente observada entre crianças e adolescentes, a existência de associação entre o excesso de peso em relação à altura e aumento da pressão sangüínea e diminuição dos níveis de Hight Density Lipoprotein - Cholesterol (HDL-C). Tal situação pode conduzir, a longo prazo, à doenças crônicas tais como a hipertensão e a aterosclerose.

Vale mencionar que além dos fatores dietéticos, os fatores genéticos contribuem também para a obesidade. Investigações científicas destacam a situação, na qual o pai e a mãe são obesos, que proporciona a probabilidade de $80 \%$ dos filhos também se tornarem obesos. De forma contrária, se os pais não apresentam sobrepeso, a proporção cai para apenas 10\% (Castro et al., 2002). 
Sobre a obesidade, cuja prevalência têm aumentado de forma substancial, entre a população de vários países em desenvolvimento, vale salientar que as conseqüências desse distúrbio são tanto psicológicas, compreendendo o estigma social associado (falta de controle, desleixo ou falta de atrativos), quanto biológica, compreendendo, neste caso, riscos, a médio e longo prazos, associados æ̀ doenças cardiovasculares, hipertensão arterial, hiperlipidemia e diabetes (Ziwiam, 1999).

Segundo Andrade (1995), análises relativas aos aspectos psicológicos, mostraram que pelo menos $76,8 \%$ dos casos de obesidade apresentaram como causa razões emocionais importantes, sendo a rejeição materna e carência de afeto a principal delas. No caso da carência afetiva a criança passa a consumir alimentos de forma exagerada na tentativa de encontrar no prazer oral, o afeto negado pela mãe e, em contrapartida, satisfazer a mãe exigente.

Para Taddei (1995), no Brasil, a obesidade infantil aumentou nos últimos anos, devido æ̀ mudanças ambientais, como o hábito das crianças, de alguns estratos de renda, se dedicarem à programação da televisão ou utilizar o computador durante várias horas por dia, situações que contribuem para a diminuição do gasto energético. Outros fatores condicionantes, ainda de acordo com o referido autor, são o desmame precoce da criança com a imediata utilização de alimentos formulados para alimentar o lactente, além da substituição de alimentos in natura preparados no domicílio por alimentos industrializados (introduzidos cada vez mais precocemente na dieta da criança), na maioria das vezes contendo valor energético superior ao recomendado para a idade.

Dados da Pesquisa Nacional sobre Saúde e Nutrição - PNSN, implementada em 1989 (IBGE, IPEA, INAN, 1990), apontam para a existência (na época) de cerca de um milhão e meio de crianças (menores de 10 anos) obesas no Brasil, sendo que a concentração estava longe de ser homogênea: as regiões Sul $(7,2 \%)$ e Sudeste $(6,2 \%)$ abrigavam a maior parte dos indivíduos obesos Os resultados deste levantamento também revelaram uma alta 
prevalência de desnutrição energético-protéica em crianças menores de 5 anos, principalmente no Norte e Nordeste, totalizando $30,7 \%$ das crianças nesta condição (Coitinho \& Leão, 1991).

Estudo transversal conduzido por Fonseca et al. (1998) revelou a prevalência de sobrepeso de $23,9 \%$ para meninos e $7,2 \%$ para meninas. A influência familiar e o sedentarismo, observado especialmente entre os meninos, foram importantes fatores no desenvolvimento do sobrepeso. Entre as meninas o percentual de sobrepeso foi menor, devido à maior preocupação com o corpo (motivações estéticas). Perseguindo modelos estéticos, as garotas muitas vezes optam pela adoção de dietas inadequadas e omissão de desjejum.

De acordo com Monteiro et al. (1995), o processo de transição nutricional no Brasil, se caracteriza pela substituição da desnutrição, decorrente da escassez de alimentos, pela obesidade, devido ao excesso de consumo alimentar. Ainda segundo esses autores, a desnutrição, embora ainda tenha grande importância para o grupo de indivíduos de menor idade, principalmente pertencentes à famílias de baixa renda, vem apresentando tendência de diminuição em todas as faixas etárias e estratos econômicos. Curiosamente, a obesidade vem aumentando em todos os estratos econômicos, principalmente nas famílias mais pobres.

Segundo Sawaya (1997), dentre as razões para a diminuição da desnutrição energético-protéica, tanto em crianças quanto em adultos, no Brasil no período de 1975 a 1989 parece ser a redução na expoliação orgânica, devido a uma redução na atividade física e a redução da incidência e severidade das infecções, com conseqüente diminuição do gasto energético, apesar da provável diminuição do consumo alimentar neste período.

Porém, a desnutrição infantil, indicada pelo comprometimento severo do crescimento linear e/ou pelo emagrecimento extremo da criança, ainda constitui um dos maiores problemas enfrentados por sociedades em desenvolvimento, seja pela sua elevada freqüência, seja pelo amplo espectro de danos que se associam àquelas condições (Monteiro \& Conde, 2000). 
Pesquisa realizada em Piracicaba, SP, tendo como amostra escolas da zona rural e urbana e alunos com idade entre 6 e 15 anos, revelou através de avaliações antropométricas, a prevalência de $4,18 \%$ de desnutrição crônica (comprometimento de altura). Tal situação pode ser considerada muito favorável quando comparada com resultados obtidos por meio de outros estudos. A proporção de alunos com indicativo de sobrepeso foi de $8,74 \%$ e $23,8 \%$ verificados entre os escolares com idade entre 6 e 10 anos e entre 11 e 15 anos, respectivamente. A situação observada reflete nitidamente a alteração do quadro nutricional da população brasileira denominado transição nutricional (Silva et al., 1999).

Segundo Escrivão \& Lopez (1995), a obesidade deve ser prevenida e controlada desde a infância, especialmente com a identificação das crianças, com idade precoce e maior predisposição para o desenvolvimento da doença, a fim de que medidas efetivas possam ser tomadas para o controle do risco, impedindo que o prognóstico seja, a longo prazo, desfavorável.

\subsection{Consumo alimentar}

Nas últimas décadas a intensificação do processo de urbanização, caracterizado principalmente pela concentração da população nas grandes metrópoles, tem contribuído de forma decisiva para alterar substancialmente a

dieta da população brasileira. A alimentação no País vem se transformando rapidamente, caracterizando-se pelo predomínio do consumo de alimentos "fora de casa" e, também, da incorporação de sanduíches e comidas rápidas (nem sempre balanceadas do ponto de vista nutricional). Essa prática vem repercutindo de forma direta na situação nutricional da população. Tem sido verificado aumento da prevalência da obesidade e crescente evolução das doenças crônico-degenerativas (Oliveira et al., 1996).

Vários estudos comprovam a relação entre a alimentação inadequada e o surgimento de doenças entre crianças e adolescentes. Cavadini (1996) relata 
que os adolescentes têm sido identificados como um grupo de risco nutricional devido aos seus hábitos alimentares.

No tocante à situação da população jovem, foi observado que o jantar é a refeição principal mais omitida pelos adolescentes, seguida pelo desjejum e que $90 \%$ dos adolescentes que não realizavam o jantar, optavam em substituí-lo por um lanche (Vieira et al., 2001).

Doyle \& Feldman (1997), em pesquisa envolvendo adolescentes de um colégio secundário particular de Manaus-AM, constataram que os estudantes revelaram predomínio da preferência pelo consumo de tipos de merendas com menor valor nutricional, embora tivessem maior custo. Quando questionados quanto à preferência de lanches, somente um dos cinco mais listados podia ser considerado lanche com alta densidade de nutrientes, pobre em gordura e rico em fibras (bruta). A totalidade dos entrevistados também demonstraram preferência por refrigerantes.

Segundo Silva (2000), a maior participação da mulher no mercado de trabalho, o crescente desenvolvimento da tecnologia e a intensificação do comércio, são fatores que vêm contribuindo decisivamente para as mudanças nos padrões alimentares e nutricionais da população brasileira. Percebe-se cada vez mais a presença marcante dos alimentos industrializados nas dietas da população brasileira.

Philippi (2000) reafirma as considerações tecidas por Silva (2000), destacando que as inovações tecnológicas advindas com o freezer e o forno de microondas contribuem de forma expressiva para a alteração dos hábitos alimentares da população, facilitando os processos culinários e poupando tempo dos responsáveis pelo preparo dos alimentos.

Bleil (1998) registrou que a população brasileira vêm incorporando, nos últimos anos, hábitos alimentares típicos da população dos países desenvolvidos. Tal situação pode ser confirmada por meio da observação da diminuição do consumo de arroz e feijão e o aumento da demanda por produtos industrializados e com maior valor agregado. 
Devido à crescente e contínua comercialização de alimentos, em grandes supermercados, adotada pelas empresas multinacionais e pela agroindústria, novos hábitos alimentares estão sendo incorporados, também, por meio de propagandas maciças sobre os alimentos industrializados, atingindo indivíduos de todas as faixas etárias (Silva, 2000).

Ainda de acordo com o referido autor, as crianças e adolescentes revelam maior tendência para incorporar novos hábitos, contribuindo para a intensa proliferação dos estabelecimentos, como exemplo, os fast food, que possuem estruturas e ambientes atrativos que valorizam os aspectos juvenis.

Segundo Vieira et al. (2001), o expressivo consumo dos alimentos conhecidos como fast-food pelos adolescentes justifica-se pelo fato de ser uma refeição rápida, cômoda, permitindo mais tempo para outras atividades.

Cabe ressaltar aqui que o fast-food geralmente apresenta-se como uma comida mais gordurosa, com maior teor de colesterol e que é preparado envolvendo uma variedade menor de alimentos (pouca variedade e quantidade, por exemplo, de hortaliças). No entanto, é importante esclarecer que este tipo de alimentação pode ser ocasionalmente consumida, ou até com relativa freqüência, desde que a dieta em seu conjunto seja saudável, ou seja, os indivíduos devem consumir hortaliças e frutas, integrantes de outras refeições do dia a fim de compensar a omissão dos referidos alimentos, em uma das refeições do dia (Angelis, 2000b).

Philippi (2000) registra que a qualidade alimentar parece ter sido prejudicada, pois em décadas passadas as refeições revelavam maior diversificação, com a inclusão de alimentos pertencentes a totalidade dos grupos da pirâmide alimentar. Atualmente, em especial os grupos das hortaliças e frutas, não se fazem presentes nas refeições diárias da maioria dos indivíduos. Além disso, nos intervalos entre as refeições tem se intensificado o consumo de alimentos conhecidos como snacks, dos salgadinhos, biscoitos, iogurtes, chocolates, sorvetes e refrigerantes. 
Segundo Cavadini (1996) o termo snacks significa uma pequena refeição geralmente realizada entre as principais refeições. Os snacks podem ser qualquer tipo de alimento. Ele é um alimento que você pode comer rapidamente, por exemplo, enquanto dirige ou enquanto vê um filme em um cinema. Os snacks podem ser representados pelas barras de chocolate, salgadinhos, mas também incluem o próprio leite, iogurte, queijo fresco, entre outros.

Tojo et al. (1996) descrevendo os hábitos alimentares da população de países industrializados, afirmam que os snacks são tipicamente ricos em carboidratos e gordura e podem corresponder a $25 \%$ ou mais da ingestão energética total de um indivíduo. Os referidos autores alegam que as crianças que consomem lanches freqüentemente tendem a comer menor quantidade de alimentos considerados de melhor qualidade nutricional e freqüentemente integrantes das principais refeições (desjejum, almoço e jantar).

Doyle \& Feldman (1997) relatam que os adolescentes não se preocupam com a qualidade nutricional dos snacks que consomem e o fator motivador primário para sua escolha parece ser o gosto, sendo os snacks com alto teor de sódio os preferidos por este grupo.

Contudo, Whybrow \& Kirk (1997) pesquisando a ingestão de nutrientes e a freqüência do consumo de snacks entre 44 estudantes do sexo feminino, com idade entre 17 e 26 anos, concluíram que os snacks por si só não comprometeram a qualidade nutricional das dietas deste grupo. Verificaram, também, que os snacks consumidos mais freqüentemente incluíam-se naquelas dietas com um número maior de refeições e com uma ampla variedade de alimentos, resultando em uma ingestão balanceada de nutrientes. Convém ressaltar também que houve significativa correlação negativa entre a freqüência de refeições e índice de massa corporal do grupo de estudantes.

Constantemente novos produtos industrializados são incorporados à prática alimentar devido à abertura das importações ou também à adoção de modernas tecnologias de cultivo e conservação de alimentos. Existem no mercado uma variedade de alimentos como os congelados, os semipreparados 
identificados, entre outros exemplos, como matinais, queijos, enlatados, conservas, que oferecem ao consumidor uma variedade de opções para compra e consumo de diferentes tipos de alimentos (Philippi, 2000).

De acordo com Bleil (1998), expressiva parcela da população do Brasil tem acesso a uma ampla variedade de alimentos mas isto não necessariamente assegura uma melhora qualitativa da dieta. Alimentos in natura como legumes e frutas ainda são consumidos em pequena quantidade: apenas $44 \%$ dos brasileiros registram que consomem frutas e $58 \%$, legumes. O impacto na saúde causado pelo consumo alimentar parece ainda não ser o fator decisivo para direcionar as compras. Ainda de acordo com o autor, a população parece lançar mão do recurso de adequar a alimentação ao poder aquisitivo e à oferta do mercado.

Com a existência de uma demanda cada vez maior por serviços de alimentação tipo fast food, observava-se, em 1998, não só a venda de hambúrguer em cadeias de loja de refeições, mas também a venda de pizzas, lanches tipo cachorro-quente, etc. Também o consumo de bebidas refrigerantes e molhos artificiais industrializados revelava crescimento, assim como produtos lácteos e sorvetes (Bleil, 1998).

De acordo com Gambardella (1995), na maioria dos inquéritos alimentares, tendo como amostra adolescentes, observava-se que as necessidades nutricionais de energia e carboidratos não eram alcançadas e o consumo de lipídeos, proteínas, ferro e vitamina $\mathrm{C}$ apresentavam-se, com maior freqüência, acima das recomendações preconizadas para o grupo.

Vieira et al. (2001) constataram, de forma bastante similar entre os adolescentes, o freqüente consumo de lanches, ricos em gordura. Em estudos dietéticos com adolescentes usualmente registra-se um desbalanço nutricional ocasionado pela falta de variedade na alimentação: é encontrado excessivo consumo energético e também de gordura saturada, colesterol, sal e açúcar. Por outro lado, verifica-se também inadequado consumo de fibras, vitaminas e minerais. 
Um estudo realizado por pesquisadores da Universidade de Harvard, concluiu que a criança que se alimenta na presença dos pais, alimenta-se melhor, quando em comparação com os indivíduos de mesma idade que fazem as refeições de forma solitária. Na mesma pesquisa foram avaliadas mais de 16.000 crianças com idade entre 9 a 14 anos observando-se o aumento do consumo de frutas e vegetais e a diminuição do consumo de frituras e refrigerantes à medida que o número de refeições aumentava, como por exemplo os jantares, com a presença dos pais à mesa. Os pesquisadores concluíram que a presença dos pais não só causa um efeito emocional positivo mas também educativo e ainda que as crianças precisam de limites, necessitando ser orientadas, pelos pais ou outros adultos, especialmente durante as refeições (Boccia, 2000).

Doyle \& Feldman (1997) em pesquisa envolvendo adolescentes, buscando conhecer a influência na escolha de snacks verificaram que as mães tiveram a maior participação (78\% das citações), seguidas pelos membros da família em geral (65\%) e pelos pais (64\%). O grupo de amigos foi responsável por $37 \%$ das citações, concluindo que a família foi a principal motivação para a escolha dos snacks. Os autores sugeriram que a educação nutricional de adolescentes provavelmente seria mais efetiva se os pais também fossem alvos desse tipo de ação.

Neumark-Sztainer et al. (1999) em pesquisa com 141 adolescentes entre 12 e 19 anos identificaram os fatores de maior influência sobre a escolha de alimentos pelo referido grupo. Entre os principais fatores incluíram-se a fome (necessidade fisiológica); atração pelos alimentos, apetite (necessidade psicológica) onde o sabor do alimento foi o item mais importante para a determinação da escolha do mesmo; tempo viável para ingerir o alimento e, enfim, sua conveniência, ou seja, consumiam os alimentos de acordo com a praticidade de preparo dos mesmos. Entre os fatores secundários, mas considerados importantes, os referidos autores incluíram a disponibilidade do alimento e a influência dos pais. Nesta pesquisa, foi verificado também que a 
influência dos pais exerceu importante contribuição, mas não primordial, na escolha dos alimentos pelos adolescentes.

Estudo realizado por Carvalho et al. (2001), com 334 adolescentes matriculados em colégio particular de Teresina (Piauí), revelou 20\% dos adolescentes com risco de sobrepeso. Os autores inferem que as práticas alimentares incorretas, observadas entre os alunos, como por exemplo a presença marcante de alimentos ou preparações gordurosas e de alimentos ricos em açúcar com reduzido conteúdo de fibra e de menor valor nutricional (exemplos: pães, balas, doces, gomas de mascar, bombons, sorvetes, refrigerantes e tabletes de chocolate) exerceram um importante papel no peso corporal observado.

Cabe ressaltar que no referido estudo os dados relativos aos adolescentes revelaram baixa freqüência de consumo de alimentos pertencentes ao grupo dos laticínios, sendo que cerca de $25,68 \%$ e $24,57 \%$ dos meninos e meninas, respectivamente, não ingeriram leite durante o período da pesquisa. Esses resultados merecem atenção pois há a preocupação em relação a maior probabilidade do risco de osteoporose futura, principalmente entre as meninas.

Pesquisa conduzida no Estado do Rio de Janeiro, envolvendo amostra de alunos (13 a 16 anos de idade) revelou que os alimentos mais freqüentemente adquiridos em supermercados, pelo grupo, foram os enlatados, iogurtes, biscoitos, queijo e presunto (Casotti et al., 1998).

Pesquisa conduzida por Gambardella et al. (1999) entre jovens (média de 14 anos de idade) do setor urbano de um município paulista, revelou baixo consumo de hortaliças e frutas, principalmente como integrantes do jantar.

Ainda de acordo com os referidos autores foi possível concluir que o lanche ocupava o lugar do jantar tradicional, pois foi observado o aumento do consumo de leite e derivados nesta refeição. Quanto ao consumo de refrigerantes, foi verificado que a bebida esteve presente em $12 \%$ dos almoços e $8 \%$ dos jantares dos jovens integrantes da pesquisa. Em relação aos demais 
tipos de bebidas, a ingestão de infusões, chá e café, foi mencionada por $15 \%$ dos adolescentes.

Pesquisa conduzida em Portugal, entre 572 escolares com idade entre 8 e 14 anos, revelou que o arroz e a batata foram os alimentos mais consumidos nas refeições identificadas como almoço e jantar. $O$ consumo de leguminosas foi baixo (17,6\% almoço e 10,8\% jantar). Revelou-se reduzido também o consumo de hortaliças e/ou saladas, cujos percentuais foram de 34,2\% e 22,7\%, respectivamente. Em relação ao leite, mais da metade do grupamento analisado apresentou consumo inferior ao recomendado. A maioria dos escolares $(68,2 \%)$ consumia, alternadamente, carne, peixe ou ovos, duas vezes por dia. O consumo de frutas foi considerado insuficiente, uma vez que cerca de metade dos alunos não tinha o hábito de ingeri-las diariamente. Em relação ao açúcar refinado, 22,4\% das crianças registraram que não haviam, no dia anterior ao inquérito, ingerido o alimento. No entanto, as bebidas açucaradas (industriais) tiveram participação de $26 \%$ na dieta dos escolares, percentual considerado expressivo pelos autores. A utilização de outras fontes fornecedoras de açúcar, como compotas ou doces do tipo marmeladas, ingeridas no desjejum ou lanche da manhã ou tarde foi referida por $21,5 \%$ dos alunos. (Figueiredo et al., 1994).

Outra constatação importante dos autores, diz respeito ao consumo de bebida alcoólica, relatado por $51,8 \%$ das crianças e adolescentes, sendo que $15,2 \%$ tinha o hábito de ingeri-la uma ou mais vezes por dia. As bebidas mais citadas foram o champanhe e o vinho português (Figueiredo et al., 1994).

Lerner (1994), avaliando as práticas alimentares de adolescentes, observou uma tendência, no início da década de 90, do aumento de consumo de refeições rápidas em detrimento de cardápios completos. Por outro lado, pôde verificar um reduzido consumo de verduras, legumes e frutas, principalmente quando se considerou os ricos em vitamina C. No estudo de Lerner (1994), assim como o de Gambardella et al. (1999) descrito anteriormente, foi identificada freqüência elevada no consumo de leite. Merece destaque a 
freqüência, no jantar dos adolescentes, dos embutidos, queijo e pão, sugerindo a substituição do consumo de alimentos tradicionais por lanche.

Os dados obtidos entre escolares de município do interior do Estado de São Paulo por Silva (1996) são concordantes com as duas pesquisas anteriores. Entre o grupo observado, em 1996, o pão foi citado com 35,0\% de freqüência de citações (no jantar), proporção superior æ̀ citações relativas ao consumo de arroz (21,3\%) e feijão (6,9\%) nas refeições. Segundo o autor, uma das explicações para a situação é que tanto o arroz como o feijão exigem maior tempo de cocção, dificultando seu preparo pelas mulheres/mães que vêm participando cada vez mais intensamente do mercado de trabalho. A mortadela, embutido mais citado pelos escolares, apareceu freqüentemente na refeição identificada como ceia $(11,1 \%)$, sugerindo que a última refeição do dia estava sendo substituída por um lanche elaborado com pão e mortadela. Os alimentos industrializados como o queijo e o iogurte receberam poucas citações de consumo. Dentre os embutidos presentes no almoço, a salsicha se destacou $(9,0 \%)$ e no jantar $(4,9 \%)$. O óleo de soja teve presença marcante na maioria das refeições, confirmando as análises elaboradas por Mondini \& Monteiro (1995) sobre a tendência da substituição de gordura animal pela vegetal.

Complementando as considerações tecidas por Silva (1996) e de acordo com Philippi (2000), o alto consumo de salsicha (cuja composição contém apenas $50 \%$ do produto de origem animal) em substituição ao consumo da carne observado entre a população infantil pode ser explicado pela facilidade e rapidez na cocção, aceitação da criança, além da ampla rede de comercialização e baixo preço.

Muitos alimentos industrializados apresentam alta densidade energética devido à grande quantidade de gordura e açúcares que os compõem. O consumo desses alimentos, de forma indiscriminada pelas crianças e adolescentes, pode contribuir para o surgimento da obesidade.

Além disso, o valor nutritivo da refeição pode ser comprometido quando os hábitos alimentares adquiridos condicionam o aumento da inclusão de 
alimentos industrializados em detrimento do consumo de alimentos in natura, como vegetais e frutas.

Segundo Philippi et al. (1999a), há pouco tempo atrás, as mães eram extremamente conservadoras, preocupando-se com a introdução de alimentos naturais e frescos nas dietas das crianças. Os roteiros alimentares constituíamse de leite materno e/ou artificial, chás, sucos e papas de frutas, papas salgadas e cereais. Com a intensificação do desenvolvimento de alimentos destinados ao público infantil (leite, papinhas, iogurtes e cereais), a facilidade de acesso à inovações tecnológicas (freezer e forno de microondas) e a crescente inserção da mulher no mercado de trabalho, as mães passaram a incorporar os alimentos industrializados àalimentação das crianças.

É interessante registrar pesquisa de Aquino (1999), envolvendo crianças (da faixa etária de zero a 60 meses) do município de São Paulo, a qual revelou quando se considerou os alimentos industrializados, que os mais freqüentes na alimentação das crianças foram: leite de todos os tipos (87,2\%), açúcar $(66,3 \%)$, amiláceos $(44,7 \%)$, biscoitos (40\%), achocolatados (19,6\%) e iogurte $(18,1 \%)$. Ainda de acordo com o autor, houve introdução muito precoce (entre zero e 5 meses) do açúcar refinado na alimentação das crianças. No segundo semestre de vida, $72,8 \%$ consumiram entre 34,3 a $49,9 \mathrm{~g} / \mathrm{dia}$, consideradas quantidades elevadas de consumo de açúcar refinado. Vale salientar que o referido consumo se revelou maior entre as crianças de famílias de baixo poder aquisitivo e cujas mães revelaram baixa escolaridade. Entre os amiláceos mais consumidos merecem destaque 0 amido de milho (Maizena ${ }^{\circledR}$ ), farinha de arroz (Cremogema $\left.{ }^{\circledR}\right)$. Trata-se de alimentos não enriquecidos e sua introdução na dieta da criança também foi precoce, mas não foi captada qualquer associação do consumo desses alimentos com o poder aquisitivo da família. Em relação aos refrigerantes, a freqüência de consumo aumentou com a idade e a partir dos 2 anos, 34,2\% das crianças já haviam consumido refrigerantes, demonstrando uma forte tendência de aumento do consumo nas faixas etárias subseqüentes (principalmente na adolescência). 
Dentre os tipos de doces, a pesquisa identificou o consumo de chocolates $(5,6 \%)$ e a partir dos 12 meses, a freqüência atingiu 8,0\%. Em relação aos achocolatados, não foi observado o consumo conforme 0 esperado pelas crianças com idade entre zero e 5 meses de idade e, entre 6 e 11 meses, a freqüência observada alcançou 5,1\%. A partir dos 12 meses, a freqüência aumentou à medida que se reduziu o consumo de amiláceos. Os cereais matinais apresentaram, baixa freqüência $(1,2 \%)$, justificada pelo fato de que as crianças não têm o hábito de consumi-los, principalmente quando se considera os indivíduos menores de cinco anos.

Ainda de acordo com o referido autor, com relação aos salgadinhos, foi possível detectar, quando comparado aos biscoitos, menor freqüência de consumo $(9,2 \%)$. No entanto, há aumento considerável do consumo conforme aumenta a idade da criança. Entre 24 e 60 meses, 16,8\% das crianças já haviam consumido salgadinhos e a tendência é de aumento do consumo com a idade. As crianças de mães que trabalhavam fora consumiram mais salgadinhos que as crianças de mães sem atividade profissional fora do domicílio. O consumo de macarrão instantâneo revelou aumento de freqüência de consumo (8,9\% para cerca de $10 \%$ ) a partir dos 12 meses de idade. Este consumo também foi maior em crianças cujas mães trabalhavam fora. Os alimentos industrializados de menor freqüência foram as sopinhas $(0,6 \%)$ e papinhas industrializadas $(0,7 \%)$.

Philippi (2000) observou forte tendência na substituição do macarrão tradicional pelo instantâneo, devido àrapidez de preparo.

Segundo Aquino (1999), não existem recomendações específicas para o consumo de alimentos industrializados na infância. No entanto, as recomendações internacionais estimulam o consumo de alimentos in natura como as frutas e vegetais. No tocante ao sal e o açúcar, há recomendação de consumo moderado. 


\subsubsection{Alimentos in natura e industrializados}

O Decreto-Lei no 986 de 21 de outubro de 1969 define como alimento in natura "todo alimento de origem vegetal ou animal para cujo consumo imediato se exija, apenas, a remoção da parte não comestível e os tratamentos indicados para a sua perfeita higienização e conservação"; os alimentos industrializados são chamados de produtos alimentícios e são definidos como "todo alimento derivado de matéria-prima alimentar ou de alimento in natura, adicionado ou não de outras substâncias permitidas, obtido por processo tecnológico adequado".

$\mathrm{Na}$ bibliografia disponível sobre o tema, os alimentos que exigem pequeno grau de processamento, identificados como beneficiados (cereais e leguminosas, por exemplo), assim como os produtos conservados (por distintos processos de frigorificação) como carnes e laticínios, são considerados alimentos industrializados (Pomeranz, 1977; Garcia et. al., 1994; Barretto \& Cyrillo, 2001).

Vale registrar que a classificação dos alimentos em in natura ou industrializado na presente pesquisa foi elaborada considerando o estado do alimento no momento da aquisição pelo consumidor, independente de tratamentos físicos e/ou químicos posteriores.

Assim, propôs-se a adoção da seguinte classificação:

A) As frutas e suco de frutas, verduras, legumes, cogumelo, ovos e mel receberam a classificação de alimentos in natura.

B) Os cereais (como o arroz e a aveia), leguminosas, as carnes refrigeradas ou salgadas, o leite pasteurizado $(A, B, C)$ ar tipo "longa vida", o açúcar, o café em pó, infusões (chás), farinhas (trigo, mandioca ou milho), hortaliças em conserva, pães, massas, bolos, biscoitos, doces, geléias, gelatinas, produtos derivados do cacau (chocolate, achocolatados), adoçante, carnes enlatadas, embutidos e outros (bacon, presunto, lingüiça, salsicha, entre outros), pescados enlatados, laticínios (iogurte, requeijão, queijos, entre outros), óleos e gorduras (óleos, margarina, manteiga, banha, entre outros), e 
preparações alimentícias diversas (lanches, pavês, feijoada, risotos, salgados, entre outros), mostarda, catchup, maionese, suco de frutas envasado, sucos artificiais em pó, tomate envasado (molho, massa, extrato, entre outros), salgadinhos tipo chips, refrigerantes, café solúvel instantâneo, farinhas mais elaboradas (Farinha Láctea ${ }^{\circledR}$ por exemplo), foram classificados como alimentos industrializados (independente do menor ou maior grau de processamento).

Vale registrar que o mundo tem passado por uma série de transformações desde a década de 50 , sendo as mais perceptíveis, a globalização e a urbanização. Essas mudanças afetam, entre outros aspectos, a qualidade dos alimentos produzidos e industrializados e também as escolhas dos consumidores, que parecem estar cada vez mais associadas a um novo estilo de vida.

Nota-se, nos países industrializados, uma tendência de se adotar novos hábitos alimentares "gerados" ou estimulados, em parte, pela indústria de alimentos em resposta às necessidades que a vida moderna impõe. Tem sido observado redução do tempo envolvido nos "rituais alimentares" desde o preparo até a ingestão e a diminuição do consumo de produtos regionais e com forte tradição cultural. Neste contexto surge um novo padrão de alimentação, o padrão das sociedades industrializadas, tanto em países desenvolvidos como os Estados Unidos e países da Europa, mas também naqueles em desenvolvimento caracterizando o padrão ocidental de alimentação.

Observa-se a evolução do consumo de alimentos industrializados, da alimentação fora do domicílio (em cantinas, restaurantes, fast-foods), a preferência pelos supermercados para a compra de alimentos, a busca de praticidade e de economia de tempo (Móron, 1996).

Neste contexto, as preferências alimentares na sociedade moderna parecem condicionadas, também, em parte, pelo substancial volume de publicidade, particularmente a relativa àalimentação. 


\subsection{Estilo de vida}

As crianças e adolescentes são consideradas integrantes de um público alvo mais susceptível às inovações e, portanto, às mudanças de comportamento. A televisão pode influir não apenas nas horas dedicadas às atividades de lazer, mas também em outras áreas, especialmente no comportamento alimentar.

Entre os diversos meios de comunicação, a televisão vem sendo considerada um dos fatores que maior impacto tem causado no modo de vida e hábitos alimentares das crianças e adolescentes. Os inúmeros comerciais veiculados diariamente estimulam o público jovem para o consumo de alimentos industrializados, identificados por diversos autores como junk food (Gittelsohn et al., 1998; Neumark-Sztainer et al., 1999; Hanley et al., 2000). Invariavelmente os referidos alimentos foram obtidos com a adoção de elevado grau de processamento, revelando, freqüentemente, alto teor de gorduras (principalmente saturada), sal, açúcar, colesterol e energia (Silva, 2000). Por outro lado, não existem incentivos veiculados especialmente pela mídia para que a população aumente o consumo de frutas e hortaliças (Linhares, 2001).

Segundo Grazini (1996), as indústrias lançam mão da necessidade do consumo de alimentos como meio de sobrevivência dos indivíduos para investirem em publicidade, elaborando comerciais dirigidos a todas as faixas etárias. Invariavelmente os comerciais são cada vez mais motivadores para que o produto seja adquirido. São adotadas variadas mensagens, freqüências e intensidade que oscilam de acordo com o planejamento publicitário de cada anunciante.

No Brasil, a televisão é um meio de comunicação bastante acessível à população, sendo encontrada tanto em casas de famílias de baixa renda (inclusive em bairros identificados como "favela"), assim como nas casas de famílias de classes intermediárias e de elevada renda (Witter, 1991).

Woodward et al. (1997) implementaram pesquisa envolvendo escolares, com idade entre 12 a 15 anos, observando que o número médio de horas por dia 
dedicadas àtelevisão foi de 3,3. Dos 22 alimentos consumidos pelos escolares enquanto assistiam aos programas de televisão, 18 deles apresentaram relação linear significativa entre horas de televisão assistidas por dia e a freqüência de consumo do alimento. $O$ estudo também apontou que os estudantes que mais tempo se dedicavam à programação televisiva, apresentavam maior tendência na escolha de alimentos menos saudáveis, sugerindo que o alto número de horas expostos aos programas da televisão possa ser útil como indicador para discriminar a existência de dietas prejudiciais àsaúde entre os escolares.

Pesquisa realizada por Borra et al. (1995) envolvendo crianças e adolescentes com idade entre 9 e 15 anos revelou que todos os integrantes da amostra concordaram que a prática regular de atividade física é boa para a saúde, porém citaram a diversão e o prazer como motivos principais para a prática de exercício físico. Os autores concluíram que a família e a escola devem assumir parte da responsabilidade, passando a desempenhar um papel ativo, com vistas à conscientização das crianças e adolescentes dos efeitos benéficos àsaúde decorrentes da prática regular de exercícios físicos.

French et al. (1994), identificaram que a prática de esportes elevou a autoestima e o apoio social e diminuiu a sensação de depressão e estresse entre os adolescentes. Além do mais, é importante lembrar que a atividade física é considerada um fator de proteção ao desenvolvimento de várias doenças crônico-degenerativas, como por exemplo, as doenças coronarianas.

Torna-se necessário, segundo Schwartzman \& Teixeira (1998) proporcionar orientações educacionais ao escolar com vistas à erradicação dos hábitos sedentários, por meio do estímulo contínuo de atividades esportivas dentro e fora do âmbito da escola. 


\section{MATERIAL E MÉTODOS}

\subsection{Local da pesquisa}

A pesquisa foi realizada no município paulista de Piedade, cuja área territorial é de $746 \mathrm{~km}^{2}$. O município possui atividades predominantemente agrícolas com propriedades que produzem vários alimentos, como por exemplo, abacate, caqui, laranja, pêssego, tangerina, abacaxi, alho, arroz, feijão, mandioca, milho, batata doce, batata inglesa, cebola e tomate (expressiva produção). Há também atividades pecuárias, com a criação de bovinos, suínos, galinhas, frangos, eqüinos, caprinos, ovinos, entre outros, e ainda a produção comercial de leite, ovos de galinha e mel de abelha (IBGE, 2002).

De acordo com o Censo Populacional de 2000, Piedade possuía 50.131 habitantes, sendo 28.074 (56,0\%) vivendo na zona rural e 22.057 (44,0\%), na zona urbana (IBGE, 2002).

Ressalta-se que, de acordo com a Fundação Instituto Brasileiro de Geografia e Estatística - FIBGE; Fundo das Nações Unidas para a Infância UNICEF (1994), 73,50\% dos chefes (ou responsáveis) dos domicílios particulares da zona rural possuíam renda mensal inferior a dois salários mínimos. No meio urbano, a proporção era menor, ou seja, $45,80 \%$ dos domicílios eram chefiados por indivíduos, cuja renda não alcançava dois salários mínimos.

Em relação ao número de escolas estaduais de ensino de $1^{\circ}$ e $2^{\circ}$ graus, Piedade possuía, segundo dados fornecidos pela Prefeitura do Município 
(março/2000), 25 escolas que atendiam 8565 alunos. Quanto à localização das escolas, cerca de $70 \%$ das unidades de ensino situavam-se na zona rural.

\subsection{População de estudo}

Com vistas à obtenção das informações relativas à rede pública de ensino (especialmente o número alunos matriculados em cada uma das unidades), foi estabelecido contato com a Secretaria Municipal de Educação.

A partir dos dados obtidos junto aos responsáveis pelo referido órgão, elaborou-se a estratificação das escolas pertencentes ao Município. As unidades de ensino foram divididas em 4 estratos, de acordo com o número de alunos matriculados. Em seguida, as 25 unidades de ensino foram distribuídas de acordo com os estratos a que pertenciam, obtendo-se o total de alunos matriculados em cada estrato, conforme mostrado (Tabela 1) a seguir.

Tabela 1. Distribuição das escolas de acordo com os estratos e o número de alunos matriculados. Piedade - SP, 2000.

\begin{tabular}{cccc}
\hline $\begin{array}{c}\text { Número de alunos } \\
\text { matriculados }\end{array}$ & $\begin{array}{c}\text { Identificação do } \\
\text { estrato de acordo } \\
\text { com o no de alunos } \\
\text { matriculados }\end{array}$ & $\begin{array}{c}\text { Número de escolas } \\
\text { pertencentes aos } \\
\text { estratos }\end{array}$ & $\begin{array}{c}\text { Total de alunos } \\
\text { matriculados }\end{array}$ \\
\hline$<250$ & A & & \\
$250 \vdash 500$ & B & 14 & 1978 \\
$500 \vdash 1000$ & C & 6 & 1984 \\
$\geq 1000$ & D & 4 & 3049 \\
Total & & 25 & 1554 \\
\hline
\end{tabular}

Para a definição das unidades de ensino, com vistas à composição da amostra representativa, foram sorteadas duas unidades de cada um dos três primeiros estratos (A, B, C). Tendo em vista a existência de somente uma escola de grande porte (número de alunos matriculados superior a 1000), a mesma foi 
incluída na amostra, assumindo assim, a representação do estrato $D$, considerado como sendo o representativo da escola com maior atendimento (1554 alunos). Desse modo, definiu-se 7 escolas integrantes da pesquisa (Tabela 2).

Tabela 2. Unidades escolares que integram a amostra da pesquisa. Piedade SP, 2000.

\begin{tabular}{|c|c|c|c|c|c|}
\hline \multirow{3}{*}{ Unidade escolar } & \multirow{3}{*}{$\begin{array}{c}\text { Identificação } \\
\text { do estrato }\end{array}$} & \multicolumn{4}{|c|}{ Séries atendidas } \\
\hline & & \multirow[t]{2}{*}{ Localização } & \multicolumn{2}{|c|}{$\begin{array}{c}\text { e nº de alunos } \\
\text { matriculados }\end{array}$} & \multirow{2}{*}{$\begin{array}{c}\text { Total de } \\
\text { alunos } \\
\text { matriculados }\end{array}$} \\
\hline & & & $1 \mathrm{a} 4^{\mathrm{a}}$ & 5 a $8^{\underline{a}}$ & \\
\hline E.E. Etelvino J. Rodriguez & $\mathrm{A}$ & Rural & 191 & - & 191 \\
\hline E.E. Padre Giorgio Musizzano & A & Rural & 169 & - & 169 \\
\hline E.E. Clementino V. Cordeiro & $\mathrm{B}$ & Rural & 180 & 241 & 421 \\
\hline E.E. Maria T. do E. Santo & B & Rural & 306 & - & 306 \\
\hline E.E. Prof. ${ }^{a}$ Maria I.A.P. Santos & C & Rural & - & 814 & 814 \\
\hline E.E. Prof. ${ }^{a}$ Maria H.S.C. César & C & Rural & - & 689 & 689 \\
\hline E.E. Prof. ${ }^{a}$ Maria P.R. Paes & $\mathrm{D}$ & Central & - & 1554 & 1554 \\
\hline Total & & & 846 & 3298 & 4144 \\
\hline
\end{tabular}

De cada um dos estratos identificados com as letras $A, B, C$ e $D$ (referentes ao total de alunos matriculados de acordo com o número de escolas pertencentes a cada estrato), foram selecionados cerca de $5 \%$ do total de alunos matriculados, totalizando 508 escolares (Tabela 3). O procedimento adotado permitiu a obtenção de uma amostra estratificada proporcional, representativa da totalidade de escolares matriculados na rede de ensino de Piedade. 
Tabela 3. Distribuição dos alunos integrantes da pesquisa, de acordo com o estrato. Piedade - SP, 2000.

\begin{tabular}{ccc}
\hline Estrato & $\begin{array}{c}\text { Total de alunos matriculados em } \\
\text { cada estrato }\end{array}$ & $\begin{array}{c}\text { Total de alunos integrantes } \\
\text { da amostra }\end{array}$ \\
\hline A & 1978 & 78 \\
B & 1984 & 132 \\
C & 3049 & 197 \\
D & 1554 & 101 \\
Total & 8565 & 508 \\
\hline
\end{tabular}

$\mathrm{Na}$ tabela apresentada a seguir, é possível verificar a composição da amostra de escolares de acordo com o sexo e faixas de idade.

Tabela 4. Distribuição dos escolares de acordo com a faixa de idade e sexo. Piedade - SP, 2000.

\begin{tabular}{cccccccc}
\hline $\begin{array}{c}\text { Estratos de idade } \\
\text { (em anos) }\end{array}$ & \multicolumn{2}{c}{ Feminino } & \multicolumn{2}{c}{ Sexo } & \multicolumn{2}{c}{ Masculino } & \multicolumn{2}{c}{ Total } \\
& № & $\%$ & № & $\%$ & № & $\%$ \\
\hline 6 ๒ 9 & 49 & 18 & 58 & 24 & 107 & {$[21,1]$} \\
$10 \longmapsto 12$ & 119 & 44 & 95 & 40 & 214 & {$[42,1]$} \\
$13 \longmapsto 18$ & 101 & 38 & 86 & 36 & 187 & {$[36,8]$} \\
Total & 269 & {$[53]$} & 239 & {$[47]$} & 508 & {$[100]$} \\
\hline
\end{tabular}

Nota: Os números entre colchetes são os percentuais em relação ao total $(n=508)$ dos escolares integrantes da mostra.

Para assegurar a participação na amostra, de forma igualitária, de escolares de ambos os sexos, julgou-se pertinente sortear 254 alunos de cada gênero. No entanto, em decorrência de situação, como por exemplo, ausência do aluno na escola, no dia programado para a coleta de dados, obteve-se uma amostra composta por 269 e 239, meninas e meninos, respectivamente.

Visando contemplar, também, a representatividade dos alunos de diferentes estratos de idade, optou-se por dividir os escolares em 3 grupos etários conforme observado na Tabela 4. 


\subsection{Delineamento da pesquisa}

Para o desenvolvimento de pesquisas epidemiológicas, tradicionalmente são adotados dois tipos de delineamentos, denominados de longitudinal e transversal.

Nos estudos longitudinais, uma amostra ou grupo populacional é selecionado e acompanhado por um determinado intervalo de tempo (podendo chegar até vários anos).

Os estudos transversais (ou de prevalência) incluem todos os indivíduos de uma determinada população (exemplo: censos) ou uma amostra da mesma e é elaborada a análise ou identificação da presença, por exemplo, de uma determinada doença (exemplo: anemia), ou de um ou mais fatores de risco, como por exemplo, baixo consumo de alimentos considerados fonte de ferro e/ou de ácido ascórbico, durante um período de tempo pré-determinado.

Geralmente os resultados são expressos em percentagens, utilizando-se distintos indicadores epidemiológicos (exemplo: Índice de Massa Corporal $\mathrm{IMC})$.

Em termos teóricos, o estudo longitudinal se revela mais apropriado. No entanto, o mesmo apresenta uma série de limitações operacionais, tais como a longa duração, perdas de unidades amostrais e variações socioeconômicas (Jelliffe, 1968).

Silva (1996) ressalta que as dificuldades e os custos inerentes a alguns tipos de pesquisas, como é o caso do estudo longitudinal, impõem uma série de restrições a sua realização em nosso meio. Devido a isso, praticamente a totalidade das informações disponíveis especificamente sobre o estado nutricional e consumo alimentar da população brasileira é obtida por meio de estudos transversais e prospectivos.

Face ao exposto, optou-se pela realização de estudo transversal, tendo por base amostra de crianças e adolescentes com idade entre seis e dezoito anos. 


\subsection{Estado nutricional}

Para as análises relativas ao estado nutricional, inicialmente foram obtidas, no âmbito das escolas, as medidas antropométricas (peso e altura) dos alunos integrantes da amostra. $O$ peso foi obtido utilizando-se balança devidamente aferida, com capacidade para até 120 quilogramas e sensibilidade de 1 quilograma. A altura foi obtida com os alunos em posição ereta, descalços, pés unidos e em paralelo, utilizando-se fitas métricas devidamente afixadas e um esquadro, sendo este firmemente apoiado sobre a cabeça.

Justifica-se a adoção da altura da criança em idade escolar como indicador do estado nutricional e das condições de saúde da população em geral, devido à vulnerabilidade da população infantil aos agravos do ambiente e à constatação de que a altura para idade nesta faixa, resume satisfatoriamente os eventos sociais, econômicos e biológicos ocorridos com a criança desde sua concepção (Valverde et al., 1985).

O critério para classificação com base nas unidades de desvio padrão ou escores $Z$ (obtido mediante o valor da variável observada no indivíduo, subtraído do valor médio de referência esperado, dividido pelo desvio padrão da população de referência) é considerado o índice mais apropriado para definir os pontos de corte na avaliação do crescimento e evolução nutricional durante a infância. A falta de simetria na distribuição de peso e altura é compensada pelo uso de distintos desvios-padrão acima e abaixo da mediana, podendo-se usar os mesmos pontos de corte para diversos índices antropométricos (World Health Organization - WHO, 1995).

O escore $Z$ é obtido mediante a subtração do valor da variável observada pelo valor da variável (mediana) esperada dividido pelo desvio-padrão de referência

Usualmente, as crianças consideradas "normais" distam até dois escores $Z$ da mediana da população de referência. Sendo assim, a criança será 
considerada com déficit de crescimento se apresentar-se abaixo de -2 desvios padrões do valor mediano para idade e sexo (Waterlow et al., 1977).

A proporção de crianças com ZAI (escore Z de altura para idade) $<-2$ pode ser utilizada, então, como indicador de desnutrição crônica. A proporção de crianças com -2 ZAI <-1, caso seja elevada, indica uma "situação de risco". A situação envolvendo o intervalo ZAl $\quad-1$, correspondem àeutrofia.

Note-se que em uma população com boas condições de saúde, espera-se encontrar, aproximadamente, $2,3 \%$ dos valores no primeiro intervalo, $13,6 \%$ estarão no segundo intervalo e os demais $84,1 \%$ deverão ter escore $Z$ igual ou superior a-1 (Silva, 1996).

Para o cálculo das idades dos escolares e dos respectivos valores dos escores Z de Altura para Idade (ZAI) utilizou-se o software Epi-Info (Dean et al., 2000).

A fim de conhecer a prevalência de sobrepeso entre crianças e adolescentes, analisou-se a distribuição dos percentis do Índice de Massa Corporal (IMC) de acordo com a idade e sexo, obtido por meio da expressão $\mathrm{IMC}=$ peso $(\mathrm{kg}) /$ estatura $(\mathrm{m})^{2}$.

Para tanto, adotou-se o valor crítico do $85^{\circ}$ percentil, conforme recomendado pela World Health Organization (WHO, 1995). Segundo o referido critério, IMC $<15^{\circ}$ Percentil (indicativo de baixo peso), 15을 Percentil $\leq \mathrm{IMC}<85^{\circ}$ Percentil (eutrofia) e IMC $\geq 85^{\circ}$ Percentil (indicativo de sobrepeso). Adotou-se o padrão de referência proposto pelo Center for Disease Control and Prevention, do National Center for Health Statistics - NCHS (2002).

Anjos (1992) afirma que apesar do IMC não indicar a composição corporal, a facilidade de sua mensuração e a grande disponibilidade de dados de massa corporal e altura, além da sua relação com morbi-mortalidade, parecem ser motivos suficientes para sua utilização como indicador do estado nutricional em estudos epidemiológicos em associação (ou não) com outras medidas antropométricas, enquanto metodologias de campo, que expressem a 
composição corporal, ainda não sejam validadas para a realização de estudos epidemiológicos.

\subsection{Consumo de alimentos e estilo de vida}

Os dados sobre as práticas alimentares e estilo de vida dos escolares foram obtidos por meio da aplicação de um questionário constituído de 23 questões, objetivas e dissertativas (Anexo A). Esse questionário, elaborado especificamente para a pesquisa, foi previamente testado em unidades de ensino com grupo de indivíduos que reuniam características (como por exemplo, situação socioeconômica e idade) semelhantes ao grupo, mas que não integravam a amostra. Cabe aqui esclarecer que visando a elaboração das análises foram selecionadas as informações que mostraram-se mais relevantes para o alcance dos objetivos da presente pesquisa.

Para a avaliação qualitativa das dietas, analisou-se a freqüência de citação dos diversos alimentos, a qual consiste na obtenção (expressa em percentagem) da freqüência em que os alimentos são citados, considerando-se o número de vezes em que o alimento aparece na dieta de cada escolar, registradas no recordatório de 24 horas. As análises permitem a identificação da freqüência do consumo dos alimentos pelos escolares.

O método qualitativo chamado questionário de freqüência alimentar também foi adotado para obtenção das informações junto aos escolares, a fim de se conhecer a dieta habitual dos mesmos.

O referido método consiste em interrogar os participantes da pesquisa, com vistas a obter os relatos de freqüência usual de consumo de cada alimento ou grupo de alimentos contidos em uma lista por um período específico de tempo. A vantagem de sua adoção é o fato de ser planejado para estimar o consumo usual de alimentos dos participantes das pesquisas, além de ser um método objetivo e operacionalizado envolvendo baixo custo, sendo facilmente 
conduzido por pessoal previamente capacitado em treinamentos de curta duração (Thompson \& Byers, 1994).

Ainda com a finalidade de se avaliar qualitativamente a dieta dos escolares, nesta pesquisa buscou-se elaborar cálculos analisando a participação relativa dos alimentos consumidos pelos escolares, agrupados de acordo com a pirâmide alimentar adaptada à população brasileira de Philippi et al. (1999b). Inicialmente, por meio da adoção do software Virtual Nutri, todos os alimentos consumidos pelos escolares foram classificados de acordo com os grupos, conforme registrado na pirâmide alimentar proposta por Philippi et al. (1999b). A referida pirâmide é composta por 8 grupos de alimentos: cereais, pães, tubérculos, raízes; hortaliças; frutas; leguminosas; leite e produtos lácteos; carnes e ovos; óleos e gorduras; açúcares e doces. Na presente pesquisa, os dois últimos grupos referidos (óleos e gorduras e açúcares e doces) que ocupam o ápice da pirâmide foram reunidos em um único grupo para a elaboração das análises. Julgou-se pertinente, também, a inclusão de dois grupos de alimentos a saber, definidos como diversos (compreendendo preparações cujos ingredientes pertenciam a dois ou mais grupos de alimentos) e o registrado como indeterminado (integrado por alimentos sem especificação de grupo, como por exemplo o chá e o café).

Em seguida obteve-se a quantidade, expressa em gramas, do consumo de cada grupo de alimento e também a soma da totalidade deles. Por meio desses dados, elaborou-se a proporção consumida de cada grupo de alimento em relação ao total consumido.

Elaborou-se também cálculos com vistas àanálise qualitativa da dieta no que tange àparticipação relativa dos macronutrientes (carboidratos, proteínas e lipídeos) no valor energético total (VET) da dieta.

Neste estudo, adotou-se os parâmetros recomendados pela National Academy of Sciences (2002) com vistas àelaboração da análise da participação dos nutrientes no valor energético total da dieta. Registra-se que os intervalos preconizados são: 45-65\% (carboidratos), 25-35\% (lipídeos) e 10-30\% 
(proteínas). As dietas dos escolares foram classificadas em adequadas (quando os valores se classificaram nos limites dos intervalos de consumo para os três macronutrientes) e inadequadas (dietas com um ou mais macronutrientes cujas análises revelaram valores que não integravam os intervalos).

As recentes mudanças estabelecidas na proporção de energia proveniente dos macronutrientes denominada Acceptable Macronutrient Distribution Ranges (AMDRs) foram definidas tendo por base evidências obtidas, efetivando-se testes intervencionais, com suporte da pesquisa epidemiológica. De acordo com a referida publicação, objetiva-se também, com a adoção dos novos parâmetros, a ampliação do papel da prevenção ou diminuição do risco, quando aumentado, de doenças crônicas e ainda a garantia da ingestão suficiente de nutrientes essenciais (National Academy of Sciences, 2002). De acordo com a recente publicação, os valores preconizados para carboidrato e gordura foram estimados tendo por base as evidências indicando risco de doença cardíaca coronariana em indivíduos que adotam dietas com baixa ingestão de gordura e elevada em carboidrato e ainda, também apoiadas em evidências do risco aumentado para obesidade e suas complicações, incluindose doença cardíaca coronariana, decorrente da alta ingestão de gordura. De acordo com a referida publicação, a evidência sugerida de que a baixa ou alta ingestão de gordura durante a infância possa levar futuramente a um risco aumentado de doenças crônicas é pouco clara. Os valores preconizados para gordura têm sido estimados para crianças principalmente baseados na transição da alta ingestão de gordura que ocorre durante a infância para a vida adulta.

Cabe salientar que no Brasil, nos últimos anos, para a elaboração de análises desse tipo, invariavelmente eram adotadas, pelos pesquisadores, as recomendações médias $(65 \%$ de carboidratos, $25 \%$ de lipídeos e $10 \%$ de proteínas) de macronutrientes preconizadas por Vannucchi et al. (1990).

Nesta pesquisa, o consumo alimentar quantitativo dos escolares foi avaliado pelo método recordatório de 24 horas. De acordo com Thompson \& Byers (1994), o método recordatório permite identificar e quantificar o conjunto 
total de alimentos e bebidas ingeridos no período (geralmente de 24 horas) anterior àentrevista.

Adotando-se o referido método, foram obtidos todos os alimentos consumidos pelos escolares no dia da semana que antecedeu a entrevista (no domicílio e fora dele, como por exemplo, alimentos consumidos em lanchonetes, bares e casa de parentes). Os alimentos foram registrados em medidas caseiras, e para facilitar o registro destas informações pelos escolares, adotouse um modelo de medidas caseiras (Anexo C).

Segundo Vasconcelos (1995), o inquérito recordatório de 24 horas é o método utilizado com maior freqüência tanto em nutrição clínica (individual), como em estudos populacionais (nutrição em saúde pública).

É importante salientar que as entrevistas, da presente pesquisa, nunca foram realizadas as segundas-feiras, a fim de se evitar a obtenção de dados atípicos, uma vez que há possibilidade da alimentação nos finais de semana diferir daquela consumida em outros dias pelos alunos. Os integrantes da amostra foram devidamente instruídos para o preenchimento correto das informações e auxiliados individualmente, quando necessário, pela autora da pesquisa e sua equipe.

Registra-se que para a elaboração dos cálculos do conteúdo de energia e nutrientes da dieta foi utilizado o software Virtual Nutri, desenvolvido por grupo de pesquisadores do Departamento de Nutrição da Faculdade de Saúde Pública da USP (Philippi et al., 1996). Cabe registrar que a autora da presente pesquisa efetuou algumas adaptações no banco de dados gerados pelo referido software para viabilizar as análises, tornando possível a compatibilização das informações com outros softwares. Foi implementada, também, uma ampla revisão e incorporação de informações relativas à composição dos alimentos, particularmente no que se refere ao conteúdo de micronutrientes.

Para a análise nutricional das dietas, adotou-se como parâmetro as recentes recomendações publicadas pela National Academy of Sciences (2000) denominadas Dietary References Intake - DRIs, as quais abrangem a maioria 
das vitaminas e alguns minerais. Para os demais nutrientes foram mantidos os valores referenciais definidos pela National Research Council - NRC (1989) denominadas Recommended Dietary Allowance - RDA.

Cabe destacar que as Recommended Dietary Allowance - RDA se tornaram o principal guia das necessidades nutricionais nos Estados Unidos e também no Brasil, devido à ausência de referências racionais atualizadas. As novas recomendações nutricionais chamadas Dietary References Intake - DRls foram definidas a partir de discussões sobre a necessidade de uma ingestão adequada de nutrientes que além de evitar deficiências, também contribuísse para a prevenção de doenças crônicas (Juzwiak, 2000).

Para a construção do banco de dados utilizou-se o software Excel (2000) e para os cálculos estatísticos adotou-se os recursos do software Statistical Analysis System - SAS (1998).

\subsection{Informações socioeconômicas da família}

As informações socioeconômicas foram obtidas mediante a adoção de questionário contendo 30 questões (objetivas e dissertativas), entregue aos alunos para que fossem encaminhados aos pais para o preenchimento (Anexo B). Após a devolução dos questionários pelas famílias, construiu-se um banco de dados, adotando-se o software Excel (2000). As análises estatísticas foram elaboradas utilizando-se os recursos do software SAS (1998).

As informações socioeconômicas analisadas na presente pesquisa referem-se à renda familiar per capita (obtida considerando-se a soma dos rendimentos de cada morador que contribuía para o conjunto das despesas da casa, dividindo-se o resultado pelo número de moradores), a escolaridade e atividade profissional da mãe. Também foram analisadas as informações relativas aos gastos com aquisição de alimentos das famílias, tendo como base o total de rendimentos. 


\subsection{Análise estatística}

Foram elaboradas tabelas de contingência envolvendo variáveis socioeconômicas como, por exemplo, renda familiar per capita e estado nutricional, acompanhadas dos testes de qui-quadrado comum e o qui-quadrado de tendência linear. Note-se que o qui-quadrado comum destina-se a captar qualquer tipo de relação entre as duas variáveis utilizadas na elaboração de tabelas de contingência. Por outro lado, o qui-quadrado de tendência linear destina-se a detectar a existência de crescimento ou diminuição da proporção de uma variável em função do nível da outra variável considerada. Sendo um teste com uma finalidade mais específica, o qui-quadrado de tendência linear é mais poderoso que o qui-quadrado comum, considerado como um teste que possibilita a captação de qualquer tipo de relação entre as duas variáveis (Mantel \& Haenszel, 1959).

Visando conhecer a correlação entre a proporção de gastos com aquisição de alimentos, em relação à renda familiar per capita, adotou-se a técnica de regressão linear simples, cujo modelo é apresentado a seguir:

$$
Y=\alpha+\beta x+u
$$

Onde $Y$ = variável dependente (proporção de gastos com alimentação)

$$
\begin{aligned}
& \alpha=\text { intercepto ou termo constante da regressão } \\
& \beta=\text { coeficiente } \\
& u=\text { erro }
\end{aligned}
$$

Com vistas a conhecer a correlação entre logaritmo das despesas com alimentação e logaritmo da renda familiar per capita, adotou-se o mesmo modelo de regresso. No entanto, a variável dependente considerada foi o logaritmo das despesas com alimentação. 


\section{RESULTADOS E DISCUSSÃO}

\subsection{Estado nutricional}

Nesta seção, serão inicialmente apresentadas as principais análises relativas ao estado nutricional dos escolares integrantes da pesquisa.

Na tabela 5 é possível conhecer a distribuição dos escolares de acordo com o estado nutricional e a escola de origem.

Tabela 5. Distribuição dos escolares em três categorias do estado nutricional, com base no escore $Z$ de altura para idade, de acordo com a unidade de ensino de origem. Piedade - SP, 2000.

\begin{tabular}{|c|c|c|c|c|c|c|c|c|}
\hline \multirow[t]{3}{*}{ Unidade de Ensino } & \multirow{2}{*}{\multicolumn{2}{|c|}{ Escolares }} & \multicolumn{6}{|c|}{ Categorias do estado nutricional } \\
\hline & & & \multicolumn{2}{|c|}{$Z A I<-2$} & \multicolumn{2}{|c|}{$-2 \leq \mathrm{ZAl}<-1$} & \multicolumn{2}{|c|}{$\mathrm{ZAI} \geq-1$} \\
\hline & № & $\% *$ & № & $\%^{* *}$ & № & $\%$ \%* & № & $\%^{* *}$ \\
\hline E.E. Etelvino J. Rodriguez & 94 & 18,50 & 7 & 25,93 & 28 & 22,05 & 59 & 16,67 \\
\hline E.E. Padre Giorgio Musizzano & 101 & 19,88 & 5 & 18,52 & 33 & 25,98 & 63 & 17,79 \\
\hline E.E. Clementino V. Cordeiro & 103 & 20,28 & 7 & 25,93 & 25 & 19,69 & 71 & 20,06 \\
\hline E.E. Maria T. do E. Santo & 41 & 8,07 & 1 & 3,70 & 13 & 10,24 & 27 & 7,63 \\
\hline E.E. Prof. ${ }^{\text {a }}$ Maria I. A P. Santos & 79 & 15,55 & 5 & 18,52 & 17 & 13,39 & 57 & 16,10 \\
\hline E.E. Prof. ${ }^{a}$ Maria H.S.C. César & 37 & 7,28 & 1 & 3,70 & 6 & 4,72 & 30 & 8,47 \\
\hline E.E. Prof. ${ }^{\text {a }}$ Maria P. R. Paes & 53 & 10,44 & 1 & 3,70 & 5 & 3,93 & 47 & 13,28 \\
\hline Total & 508 & 100,00 & 27 & {$[5,3]$} & 127 & {$[25,0]$} & 354 & {$[69,7]$} \\
\hline
\end{tabular}

* Valores percentuais relativos ao total de escolares $(n=508)$ integrantes da amostra.

** Os percentuais foram calculados, tendo por base o número (total) registrado na coluna.

Nota: os números entre colchetes são os percentuais em relação ao total $(n=508)$ dos escolares integrantes da amostra.

Tendo por base os dados da Tabela 5, observa-se que a proporção $(5,3 \%)$ de escolares com escore ZAl $<-2$ (indicativo de déficit de altura) é superior à esperada (2,3, proporção observada nos grupos adotados como referência). Assim, verifica-se que na amostra há aproximadamente 3,0\% dos 
escolares com déficit de altura, resultado que pode ser considerado satisfatório, tendo em vista que a maioria dos alunos residem na zona rural do município.

Estudo desenvolvido por Silva et al. (1999), envolvendo 16.093 escolares de ambos os sexos, com idade entre 6 a 15 anos, residentes em Piracicaba $\mathrm{SP}$, revelou que $4,18 \%$ dos escolares apresentaram $\mathrm{ZAI}<-2$.

$O$ resultado obtido entre os escolares de Piedade é semelhante à realidade observada entre os 16.093 escolares. No entanto, vale esclarecer que a pesquisa conduzida em Piracicaba não envolveu alunos residentes na zona rural.

Merece destaque, também, a comparação entre os resultados obtidos na presente pesquisa e os dados encontrados por Amigo et al. (1995). Os referidos autores analisaram a situação nutricional de escolares pertencentes aos estratos de baixo nível socioeconômico da cidade de São Paulo e Santiago (Chile), observando prevalência de retardo de crescimento de $23,1 \%$, entre a população infantil de São Paulo, enquanto em Santiago a proporção atingiu 39,9\%.

Pesquisa de Corso (1996), envolvendo 4.591 crianças de escolas públicas e particulares, ingressantes no $1^{\circ}$ grau da rede básica de ensino do município de Florianópolis - SC, revelou prevalência de $3,1 \%$ de déficits de altura, proporção muito próxima àesperada $(2,3 \%)$.

A proporção de escolares pertencentes ao intervalo -2 ZAl $<-1$, mostra-se elevada (25\%), superior a $13,6 \%$ adotado como padrão de referência, indicando situação que merece atenção, pois trata-se de grupo que revela ligeiro comprometimento da altura. O resultado aponta para a necessidade de monitoramento ou vigilância do crescimento desse grupo de alunos para que não sejam expostos às situações que contribuam para o agravo do estado nutricional.

A situação correspondente aos indivíduos com ZAI $\quad-1$, identifica o grupo de escolares considerados eutróficos. Verificou-se, portanto, que a proporção de escolares nessa situação $(69,7 \%)$ é menor que à esperada $(84,1 \%)$ quando se adota como parâmetro populações de referência (NCHS, 2002). 
A realidade observada entre os escolares de Piedade no que tange à situação nutricional pregressa pode ser considerada bastante satisfatória. Notese que substancial parcela da amostra de escolares vivem na zona rural do município. Tradicionalmente, no Brasil, é no meio rural que se concentra a maior proporção de indivíduos com déficit de altura, tendo como comparação a situação nutricional da população residente nas regiões urbanas.

Tendo em vista que a presente pesquisa visou analisar, entre outros fatores, a participação dos alimentos industrializados no consumo total de alimentos dos escolares, julgou-se pertinente explorar, de forma pormenorizada, a situação do estado nutricional atual (identificado pela classificação do IMC, de acordo com a distribuição dos percentis) e sua associação com algumas variáveis socioeconômicas e de estilo de vida.

Os principais resultados obtidos foram reunidos nas Tabelas 6,7 e 8 , apresentadas a seguir.

Tabela 6. Distribuição dos escolares com base no Índice de Massa CorporalIMC e estratos de renda familiar per capita. Piedade - SP, 2000.

\begin{tabular}{|c|c|c|c|c|c|c|c|c|}
\hline \multirow{3}{*}{$\begin{array}{l}\text { Renda Familiar Per Capita } \\
\text { (em Reais) }\end{array}$} & \multicolumn{6}{|c|}{ Índice de Massa Corporal } & \multirow{2}{*}{\multicolumn{2}{|c|}{ Total }} \\
\hline & \multicolumn{2}{|c|}{$<15^{\circ} \mathrm{P}$} & \multicolumn{2}{|c|}{$15^{\circ} \mathrm{P}-85^{\circ} \mathrm{P}$} & \multicolumn{2}{|c|}{$\geq 85^{\circ} \mathrm{P}$} & & \\
\hline & № & $\%$ & № & $\%$ & № & $\%$ & & \\
\hline zero $^{(*)}$ & 5 & $\begin{array}{l}10,9 \\
(7,0)\end{array}$ & 37 & $\begin{array}{c}80,4 \\
(17,0)\end{array}$ & 4 & $\begin{array}{c}8,7 \\
(12,5)\end{array}$ & 46 & {$[14,3]$} \\
\hline $0-80$ & 37 & $\begin{array}{c}25,9 \\
(52,1)\end{array}$ & 89 & $\begin{array}{c}65,2 \\
(40,8)\end{array}$ & 17 & $\begin{array}{r}11,9 \\
(53,1)\end{array}$ & 143 & {$[44,6]$} \\
\hline $80 \mathrm{I}-160$ & 18 & $\begin{array}{c}21,9 \\
(25,4)\end{array}$ & 59 & $\begin{array}{l}72,0 \\
(27,2)\end{array}$ & 5 & $\begin{array}{c}6,1 \\
(15,6)\end{array}$ & 82 & {$[25,6]$} \\
\hline$\geq 160$ & 11 & $\begin{array}{c}22,0 \\
(15,5)\end{array}$ & 33 & $\begin{array}{c}66 \\
(15,0)\end{array}$ & 6 & $\begin{array}{c}12,0 \\
(18,8)\end{array}$ & 50 & {$[15,5]$} \\
\hline Total & 71 & {$[22,1]$} & 218 & {$[67,9]$} & 32 & {$[10,0]$} & 321 & {$[100,0]$} \\
\hline
\end{tabular}

$x^{2}=7,55$, com 6 graus de liberdade, não-significativo.

$\chi^{2}(\mathrm{MH})=0,36$, com 1 grau de liberdade, não-significativo.

Nota: os números entre parênteses são os percentuais em relação ao total observado na coluna.

os números entre colchetes são os percentuais em relação ao número total de escolares $(n=321)$ observado para os quais se dispõe de informações válidas.

(*) renda declarada pelos pais ou responsáveis = zero. 
Ao examinar os dados mostrados na Tabela 6 verifica-se que, de forma geral, $22,1 \%$ dos escolares foram classificados abaixo do 15 $\mathrm{P}$ (indicativo de baixo peso), valor considerado acima do esperado (15\%), quando se considera os valores observados em populações adotadas como referência. Analisando a variação das proporções de escolares considerados de baixo peso, de acordo com os estratos de renda familiar, é possível verificar que maior percentual $(52,1)$ é encontrado no grupo com renda familiar per capita entre zero e oitenta reais.

Analisando-se a prevalência de escolares identificados com IMC $\geq 85^{\circ} \mathrm{P}$ observa-se apenas $10 \%$, valor considerado inferior ao esperado (15\%). É interessante frisar que ao considerar os dados relativos à distribuição dos 32 alunos $\left(10 \%\right.$ com IMC $\left.\geq 85^{\circ} \mathrm{P}\right)$ de acordo com os estratos de renda familiar, verifica-se que a maior proporção $(53,1 \%)$ possui renda entre zero e $R \$ 80,00$. Entre o grupo de alunos considerados mais ricos (renda familiar pelo menos igual a $\mathrm{R} \$ 160,00), 18,8 \%$ foram classificados com IMC $\geq 85^{\circ} \mathrm{P}$. Note-se que a referida proporção é ligeiramente superior àesperada (15\%).

Pesquisa denominada NHANES III (3 ${ }^{\text {a }}$ Pesquisa de Investigação de Nutrição e Saúde Nacional), realizada nos Estados Unidos durante o período entre 1988 e 1991, com o objetivo de avaliar a prevalência de sobrepeso entre crianças e adolescentes com idade entre 6 a 17 anos, mostrou, quando se adotou o nível crítico do 85ำ percentil, que a proporção alcançava 22\% (Troiano et al., 1995).

A seguir é apresentada a distribuição dos escolares, integrantes da presente pesquisa, de acordo com o IMC e atividade profissional da mãe (Tabela $7)$. 
Tabela 7. Distribuição dos escolares com base no Índice de Massa Corporal IMC e a atividade profissional da mãe. Piedade - SP, 2000.

\begin{tabular}{|c|c|c|c|c|}
\hline \multirow{2}{*}{ Atividade profissional da mãe } & \multicolumn{3}{|c|}{ Índice de Massa Corporal } & \multirow{2}{*}{ Total } \\
\hline & $<15^{\circ} \mathrm{P}$ & $15^{\circ} \mathrm{P}-85^{\circ} \mathrm{P}$ & $\geq 85^{\circ} \mathrm{P}$ & \\
\hline Trabalha fora de casa & $\begin{array}{c}23 \\
(57,5)\end{array}$ & $\begin{array}{c}152 \\
(54,1)\end{array}$ & $\begin{array}{c}18 \\
(34,6)\end{array}$ & $193[51,7]$ \\
\hline Não trabalha fora de casa & $\begin{array}{c}17 \\
(42,5)\end{array}$ & $\begin{array}{c}129 \\
(45,9)\end{array}$ & $\begin{array}{c}34 \\
(65,4)\end{array}$ & $180[48,3]$ \\
\hline Total & $40[10,7]$ & $281[75,3]$ & $52[14,0]$ & $373[100,0]$ \\
\hline
\end{tabular}

Ao examinar os dados da Tabela 7 , observa-se que $51,7 \%$ das mães exercem atividades remuneradas fora de casa.

Quando se examina a distribuição dos alunos classificados de acordo com - IMC e atividade profissional da mãe verifica-se que, entre os integrantes do grupo ( $n=40$ ) com IMC $<15^{\circ} \mathrm{P}$ (indicativo de baixo peso), a maioria das mães $(57,5 \%)$ trabalha fora de casa.

Situação inversa é observada para os alunos identificados $(n=52) \mathrm{com}$ indicativo de sobrepeso (IMC $\geq 85^{\circ} \mathrm{P}$ ). Entre esses, $65,4 \%(n=34)$, têm mães que não trabalham fora. Infere-se que os escolares cujas mães não trabalham possuem renda familiar mais estável ou possivelmente até maior, quando comparadas com as famílias identificadas como "quebradas", ou seja, famílias mantidas sob a responsabilidade exclusiva da mulher. Vale lembrar que freqüentemente as mulheres, especialmente em regiões rurais, que assumem a responsabilidade dos cuidados e manutenção econômica da família de forma praticamente sozinha, revelam pouca escolaridade e, conseqüentemente, ao participarem do mercado de trabalho, também recebem salários muito baixos. 
Tabela 8. Distribuição dos escolares com base no Índice de Massa Corporal IMC e o costume de consumir alimentos fora de casa. Piedade - SP, 2000.

\begin{tabular}{|c|c|c|c|c|}
\hline \multirow{2}{*}{ Consumo de alimentos fora de casa } & \multicolumn{3}{|c|}{ Índice de Massa Corporal } & \multirow{2}{*}{ Total } \\
\hline & $<15^{\circ} \mathrm{P}$ & $15^{\circ} \mathrm{P} \vdash 85^{\circ} \mathrm{F}$ & $\geq 85^{\circ} \mathrm{P}$ & \\
\hline Sim & $\begin{array}{c}14 \\
(326)\end{array}$ & $\begin{array}{c}109 \\
(368)\end{array}$ & $\begin{array}{c}15 \\
(278)\end{array}$ & $138[35,1]$ \\
\hline Não & 29 & 187 & 39 & $255[64,9]$ \\
\hline Total & $43[11,0]$ & $296[75,3]$ & $54[13,7]$ & $393[100,0]$ \\
\hline
\end{tabular}

$\chi^{2}=1,78$, com 2 graus de liberdade, não-significativo.

$\chi^{2}(\mathrm{MH})=0,37$, com 1 grau de liberdade, não-significativo.

Nota: - os números entre colchetes são os percentuais em relação ao número de escolares $(n=393)$ para os quais há disponibilidade das informações envolvidas na análise.

- os números entre parênteses são os percentuais em relação ao total observado em cada coluna.

Note-se que entre os alunos $(n=54)$ identificados com IMC $\geq 85^{\circ} \mathrm{P}$, $72,2 \%$ não costumam consumir alimentos fora de casa. Tal resultado pode ser condicionado, pelo menos em parte, pelo nível de renda das famílias e, também, pelo fato do município ser classificado como relativamente pequeno e manter características típicas da zona rural, onde o consumo de alimento ainda ocorre, de maneira preponderante, no domicílio. No entanto, não foi possível captar a associação estatisticamente significativa entre as variáveis consideradas.

Pesquisa de Oetterer et al. (1999), envolvendo 10 municípios brasileiros (Parnaíba e Brasileira - PI, Abaetetuba e Tailândia - PA, Contagem e Baldim MG, Anápolis e Itaguaru - GO, e Joinville e P. Serrada - SC), mostrou que do total de 2348 escolares (matriculados em escolas centrais e da periferia), apenas $135(5,75 \%)$ relataram que consumiam alimentos fora do domicílio. Comparando os resultados obtidos por Oetterer et al. (1999) e os dados dos escolares de Piedade é possível observar que o costume de consumir alimentos fora do domicílio, manifestado pelos alunos, é substancialmente maior $(35,1 \%)$ quando se compara com a reduzida proporção $(5,75 \%)$, encontrada pelos referidos autores, tendo por base dados de dez municípios brasileiros. 


\subsection{Consumo alimentar}

\subsubsection{Análises qualitativas}

Nesta seção, serão apresentadas as análises qualitativas do consumo alimentar, tendo por base a amostra dos escolares.

$\mathrm{Na}$ Tabela 9 são mostrados os dados referentes à distribuição das citações de alimentos presentes na dieta dos escolares.

Tabela 9. Freqüência de citações dos alimentos. Piedade - SP, 2000.

\begin{tabular}{lcc}
\hline \multicolumn{1}{c}{ Alimento } & № & $\begin{array}{c}\text { Freqüência de } \\
\text { citaç̃es (\%) }\end{array}$ \\
\hline Arroz & 480 & 94,5 \\
Pães & 453 & 89,2 \\
Feijão & 451 & 88,8 \\
Hortaliças & 433 & 85,2 \\
Leite & 402 & 79,1 \\
Carne bovina & 292 & 57,5 \\
Café & 257 & 50,6 \\
Margarina & 231 & 45,5 \\
Achocolatado em pó & 195 & 38,4 \\
Carne de frango & 187 & 36,8 \\
Biscoitos (simples e recheados) & 146 & 28,7 \\
Macarrão & 142 & 28,0 \\
Refrigerantes & 116 & 22,8 \\
Suco de frutas naturais & 114 & 22,4 \\
Frutas & 90 & 17,7 \\
Salsicha & 89 & 17,5 \\
Sucos artificiais & 84 & 16,5 \\
Bolos (simples e recheados) & 59 & 11,6 \\
Ovos & 47 & 9,3 \\
Balas & 44 & 8,6 \\
Salgadinhos tipo "chips" & 40 & 7,9 \\
Queijos & 28 & 5,5 \\
Chocolates & 25 & 4,9 \\
Chicletes & 15 & 3,0 \\
Requeijão & 8 & 1,5 \\
logurtes & 6 & 1,2 \\
Peixe & 5 & 1,0 \\
Salame & 4 & 0,8 \\
Sanduíches & 4 & 0,8 \\
Pirulitos & 3 & 0,6 \\
Catchup & 2 & 0,4 \\
Farinha láctea & 1 & 0,2 \\
Aveia & 1 & 0,2 \\
\hline & &
\end{tabular}


Dentre as citações, destaca-se a maior freqüência de consumo do arroz $(94,5 \%)$, pães $(89,2 \%)$, feijão $(88,8 \%)$, hortaliças $(85,2 \%)$, leite $(79,1 \%)$ e carne bovina $(57,5 \%)$. Cabe mencionar também as citações do café $(50,6 \%)$, margarina $(45,5 \%)$, achocolatado em pó $(38,4 \%)$, biscoitos $(28,7 \%)$, macarrão $(28,0 \%)$ e refrigerantes $(22,8 \%)$. Destaca-se que a freqüência de citações dos refrigerantes praticamente empata com o número de citações registradas para o suco de frutas naturais $(22,4 \%)$ e a freqüência de citações relativas às frutas $(17,7 \%)$. É interessante notar que os sucos artificiais (16,5\%) foram citados com menor freqüência, quando se compara com os dados relativos aos sucos de frutas naturais $(22,4 \%)$. Trata-se de um resultado interessante, pois indica a priorização dos alimentos naturais para a elaboração de sucos, consumidos pelos escolares.

Inversamente, algumas das menores freqüências de citações foram atribuídas ao peixe (1\%), mesmo quando se considerou os tipos em "conserva" ou frito; salame $(0,8 \%)$, sanduíches $(0,8 \%)$, farinha láctea $(0,2 \%)$, aveia $(0,2 \%)$, entre outros.

Deve-se enfatizar a freqüência de citações atribuídas ao arroz (94,5\%) e ao feijão $(88,8 \%)$, alimentos considerados, tradicionalmente, como integrantes básicos da dieta da população brasileira. Entre os escolares, integrantes da amostra, 89\% relataram consumo diário de arroz, enquanto proporção inferior (76\%), registrou consumo diário de feijão. Segundo Mahan \& Arlin (1994) a combinação de cereais e leguminosas, que apresentam baixos teores de lisina e metionina, respectivamente, resultará numa mistura adequada para a síntese de proteínas. Esta complementaridade entre as proteínas também se revela importante para indivíduos, cuja situação socioeconômica, por exemplo, restrinja a quantidade de proteína animal disponível para a alimentação.

Priore (1996) avaliando os hábitos alimentares de 95 adolescentes residentes em favelas, observou ao analisar a ingestão de arroz com feijão, que $90,2 \%$ dos adolescentes consumiram a mistura dos alimentos pelo menos uma vez ao dia. 
Em relação aos pães, uma das hipóteses para o elevado número de citações $(89,2 \%)$ deve-se ,em parte, à substituição das refeições tradicionais (almoço e jantar) por pão com margarina, embutido, entre outros. Pesquisa de Caroba (2002) envolvendo o consumo alimentar de adolescentes, também registrou um número elevado de citações para os pães (79,4\%), porém, menor, quando comparada com os dados obtidos junto aos escolares de Piedade.

Enfatiza-se o número de citações da freqüência $(85,2 \%)$ de consumo de hortaliças, considerado elevado. No entanto registra-se que apenas $51 \%$ informaram que as consomem diariamente, enquanto $35 \%$ o fazem duas vezes por semana. A maior participação no consumo foi observada para a alface com $31,1 \%$ das citações, seguida pela batata inglesa $(18,1 \%)$ e pelo tomate $(12,4 \%)$. Tais resultados possivelmente decorrem da maior disponibilidade de hortaliças nos domicílios dos escolares. Vale frisar que Piedade é um dos maiores produtores de hortaliças do estado de São Paulo.

Outros fatores que também devem ser considerados referem-se à expressiva adesão dos escolares ao programa de merenda escolar. Na presente pesquisa foi observado que $73,9 \%$ dos alunos declararam que consomem diariamente a merenda distribuída gratuitamente nas unidades de ensino. Entre esses ( $n=374$ ou $73,9 \%$ ), $72,4 \%$ informaram que as hortaliças integram, rotineiramente, as refeições do programa de merenda escolar.

Carvalho et al. (2001) em pesquisa envolvendo adolescentes, matriculados em colégio particular de Teresina, verificaram que a freqüência semanal de consumo (ao menos uma vez por semana) das hortaliças foi de $56,55 \%$ para as meninas e $52,04 \%$ para os meninos.

Pesquisa de Priore (1996), visando a análise dos hábitos alimentares dos adolescentes, especialmente no que diz respeito ao consumo de hortaliças, classificou os vegetais consumidos em dois grupos, o grupo A (teor de carboidratos até $5 \%$ ) e B (teor de carboidratos até $10 \%$ ). Somente $39,1 \%$ dos adolescentes alegaram consumir alimentos do grupo A e 7,6\%, do grupo B. Em compensação, 66,7\% dos adolescentes afirmaram o consumo de vegetais do 
grupo A uma vez por dia e para os vegetais do grupo $B, 71,4 \%$ referiram ingerilos com a mesma periodicidade. Quando se considera o consumo de vegetais realizado duas vezes por semana, as percentagens de 30,6 e 28,6 foram registradas para os vegetais do grupo $A$ e $B$, respectivamente.

A freqüência de citação referente æ̀ frutas foi baixa $(17,7 \%)$, entre os alunos integrantes da presente pesquisa, mesmo se for considerada a comodidade de ingerir algumas frutas in natura, que invariavelmente demandam poucos cuidados higiênicos para serem consumidas, além de facilidades de produção, tendo em vista a área do município ocupada pela zona rural. Enfatizase, também, que apenas $36 \%$ dos escolares registraram que consomem frutas diariamente, enquanto $49 \%$, somente duas vezes por semana. Entre as frutas, a banana foi a mais citada $(7,6 \%)$ e entre os sucos de frutas naturais $(22,4 \%$ das citações), o maior número de citações recaiu para o suco de laranja $(15,9 \%)$. Pesquisa implementada por Caroba (2002), envolvendo amostra de adolescentes matriculados na rede pública de ensino revelou o contrário, sendo registrada uma discreta preferência, manifestada pelos adolescentes, por frutas $(54,9 \%)$ e sucos de frutas $(54,8 \%)$ em comparação com as verduras $(51,8 \%)$.

Watt \& Sheiham (1996) estudando os hábitos alimentares de 479 adolescentes, com idade entre 13 e 14 anos, moradores em Londres, verificaram que somente $25,9 \%$ consumiram frutas com freqüência maior que uma vez por dia. Para o suco de frutas, a percentagem observada foi cerca de $22 \%$.

Nesta pesquisa, o número de citações relativas ao consumo de leite $(79,1 \%)$, pode ser considerado um resultado positivo. Entre os escolares, $69 \%$ fizeram referência ao consumo da bebida diariamente. Lerner (1994) em sua pesquisa sobre a prática alimentar de adolescentes considerou elevada a freqüência de consumo para o leite, sendo 948 vezes citado, quando se considera o total de 4816 refeições (desjejum, lanche/manhã, almoço, lanche/tarde, jantar e lanche/noite) analisadas. O leite se caracterizou como o principal alimento do desjejum, entre a população avaliada. 
Os resultados obtidos para os escolares de Piedade revelam, curiosamente, o maior número de citações para a carne bovina $(57,5 \%)$, alimento com custo mais elevado quando comparado àcarne de frango $(36,8 \%)$. O resultado difere daqueles obtidos por Santana (1999) sobre as mudanças recentes na demanda de carne no Brasil que revelou tendências do aumento do consumo da carne de frango. As motivações para o aumento do consumo não se limitam somente à agregação de valor, mas também é estimulado pela diversificação e pelo atendimento æ̀ necessidades do consumidor e, principalmente, ao marketing, que o caracterizou como produto alimentar de alta qualidade e saudável, no que se refere à prevenção de doenças do coração e a obesidade. Dentre outras fontes protéicas, a salsicha recebeu $17,5 \%$ das citações e os ovos (alimento considerado de baixo preço quando comparado às carnes) receberam apenas $9,3 \%$ de citações. Alimentos como o requeijão e os iogurtes, produtos que apresentam maior custo e muitas vezes considerado de difícil acesso por populações mais carentes, receberam 1,5\% e 1,2\% de citações, respectivamente.

O fígado, víscera considerada um alimento importante no combate à anemia, não integra o rol dos alimentos que receberam elevado número de citações. Na realidade, $61 \%$ dos escolares entrevistados não fizeram referência ao consumo desse alimento. Porém, o consumo de embutidos, alimentos ricos em gordura e sal, receberam $54 \%$ de citações dos escolares que relataram consumi-los duas vezes por semana.

Note-se que a freqüência de citações para o café revelou-se maior que à verificada para o achocolatado em pó. Registra-se que o achocolatado é alvo de maior volume de propaganda veiculada pela mídia e, freqüentemente, tem maior preço. É possível que devido ao custo o consumo entre os escolares seja menos freqüente quando comparado ao café. Vale lembrar também que se analisado o rendimento desses dois tipos de alimentos, é possível que o café revele um maior rendimento e portanto a população tem, dessa forma, acesso a um alimento de menor preço. Tendo em vista as características da população de 
Piedade, é possível que o consumo de achocolatados ainda não tenha sido incorporado ao padrão alimentar da população.

De acordo com Guesry (1996), o café contém cerca de $80 \mathrm{mg}$ de cafeína/xícara, podendo causar problemas de insônia em crianças. Além disso, registra-se que esse alimento apresenta baixo valor nutricional quando comparado ao achocolatado, geralmente enriquecido com vitaminas e sais minerais e, portanto, de maior valor nutricional.

Ressalta-se a baixa citação, entre os escolares, atribuída aos sanduíches. Presume-se que tal fato decorra da ausência, no município de Piedade, de estabelecimentos comerciais do tipo Shopping Center, local que normalmente abriga as áreas identificadas como "praças de alimentação", as quais atraem elevado contingente de crianças e jovens. O rendimento familiar, considerado baixo, o local da moradia (sendo que substancial parcela da população reside na zona rural do município) e o estilo de vida, predominante entre a população, no que se refere ao maior consumo de refeições no âmbito domiciliar, parecem ser fatores que contribuem para a baixa freqüência de citações relativas ao consumo de lanches, especialmente aqueles comercializados em ruas e outros estabelecimentos populares.

Os dados da presente pesquisa foram confrontados com os dados obtidos por Cross et al. (1994), que visaram identificar a freqüência dos tipos de lanches consumidos por adultos e crianças entre as refeições principais. Os autores, tendo como grupo amostral 1800 americanos, observaram, entre os préescolares, que praticamente a totalidade $(92,6 \%)$ consumia pelo menos um lanche por dia. Entre os alimentos mais consumidos, merecem destaque a segunda posição ocupada pelos biscoitos $(23,9 \%)$, seguida pelos bolos $(22,2 \%)$, salgadinhos $(21,1 \%)$ e pães $(18,8 \%)$. De acordo com os autores, o consumo de salgadinhos, biscoitos, pipoca e batatas (tipo chips) pode ser considerado elevado para as crianças, adultos e idosos. Contudo merece destaque o predomínio do consumo entre os grupamentos de jovens. 
Com base nos referidos dados, pode-se observar diferenças significativas, tomando por referência a amostra de alunos de Piedade, especialmente no tocante ao consumo de lanches. As citações, entre os escolares da presente pesquisa, se revelaram inferiores a $1,0 \%$ para os lanches, enquanto os salgadinhos representaram $7,9 \%$ das citações e os bolos, $11,6 \%$. O consumo de biscoitos $(28,7 \%)$ é similar aos dados encontrados para a população infantil americana e o consumo de pães $(89,2 \%)$, mais elevado. Nota-se que o consumo de alimentos com maior grau de processamento é mais elevado, como esperado, entre os americanos, cujo país vivenciou com pioneirismo o processo da transição nutricional.

O peixe, assim como a aveia, embora pertencentes a distintos grupos, apresentaram freqüências de citações muito baixas, revelando que estes tipos de alimentos possivelmente não são apreciados pelos escolares ou não valorizados pelos familiares responsáveis pela aquisição e preparo dos alimentos. Parece ser necessário, portanto, empreender esforços para ampliar a divulgação da importância da incorporação desses alimentos na pauta alimentar (com o aumento a oferta do consumo de peixes, por exemplo, por meio da implantação de criadouros no município) e estimulando, preferencialmente, as mães para que ofereçam estes tipos de alimentos para seus filhos, desde os primeiros anos de vida. Há ainda a possibilidade de incluir o pescado nos cardápios das creches do município. Tal iniciativa certamente contribuirá para a consolidação, de forma precoce, do hábito entre as crianças.

Pesquisa de Yuyama et al. (2000) revelou que os hábitos alimentares de pré-escolares dos municípios Barcelos e Ajuricaba - Estado do Amazonas caracterizam-se pela influência cultural arraigada que contribui para $\circ$ baixo consumo de verduras e frutas, apesar da grande disponibilidade desses frutos nas localidades. Os referidos autores chamam a atenção para o fato dos dez alimentos mais citados pelas crianças não incluírem as frutas e hortaliças. Por sua vez, o consumo de farinha de mandioca, alimento típico da região, ocupou o primeiro lugar, recebendo $68 \%$ de citações. Destaca-se também o peixe, 
alimento característico da região, que alcançou $50,5 \%$ das citações, enquanto o arroz e feijão alcançaram $46 \%$ e $27,5 \%$, respectivamente. Salienta-se, ainda, o número de citações para o café (26\%) e principalmente a reduzida proporção de citação atribuída ao leite $(9,0 \%)$, que indica que a bebida não pode ser considerada um alimento integrante dos hábitos alimentares da população.

Pesquisa conduzida por Nuzzo (1998), entre adolescentes pertencentes à instituição particular de ensino, revelou que dentre os alimentos com maior freqüência de citações, mereceu destaque, ocupando o primeiro lugar o leite, seguido do arroz. Em termos da participação, na dieta, os dados mostraram a forte presença das guloseimas (chocolates, balas, chicletes e outros) e dos salgados (pastéis, coxinha, pão de batata, pão de queijo, entre outros). A presença do refrigerante foi elevada, contribuindo para o aumento da presença de carboidratos simples na dieta. Embora os salgadinhos e batata (tipo chips) tenham sido citados com baixa freqüência, quando somadas à freqüências verificadas para os salgados gordurosos, contribuíram para o aumento da ingestão de gordura, a qual de acordo com o autor também se revelou elevada.

Comparando-se os dados obtidos entre os escolares de Piedade com os resultados verificados por Nuzzo (1998) é possível verificar que o arroz ocupa, nas duas pesquisas, posição semelhante assim como também o leite. $O$ consumo de guloseimas não foi elevado, entre o grupo de escolares de Piedade, que revelou ainda $4,9 \%$ de citações para os chocolates, 8,6\% para as balas, $3,0 \%$ para os chicletes e $0,6 \%$ para os pirulitos. O consumo de salgados também foi baixo, recebendo $5,5 \%$ das citações.

Análises mais recentes, implementadas por Caroba et al. (2000), referentes à participação dos alimentos industrializados na dieta de grupamentos de escolares com idade entre 9 e 16 anos, residentes no setor urbano do município de Piracicaba-SP, apontaram para a presença nas refeições avaliadas, de 44 tipos diferentes de alimentos industrializados. O leite apareceu com maior freqüência de citações $(70,8 \%)$, seguida pelo achocolatado $(38,7 \%)$ e pelo café e biscoitos recheados, ambos com $34,0 \%$ de citações. Os derivados do 
leite tiveram baixa freqüência: iogurtes $(8,5 \%)$, queijo frescal $(4,7 \%)$ e requeijão $(3,8 \%)$. Os resultados relativos æ̀̀ citações do café foram surpreendentes, pois alcançaram 34,0\%. Outro aspecto interessante refere-se à citações de alimentos tipo mostarda, catchup, hambúrguer, geléia, pastel, salame e margarina que receberam um número muito reduzido de citações (não alcançando 1,0\%).

Comparando-se os resultados da presente pesquisa com as análises implementadas por Caroba et al. (2000), percebe-se que em Piedade, mesmo sendo um município com predomínio da população moradora na zona rural, os escolares citaram volume expressivo de consumo de tipos de alimentos industrializados (155 tipos). O leite, o achocolatado e o café também receberam elevado número de citações, sendo que o café recebeu uma freqüência de citação de 50,6\% e o mesmo alimento, na pesquisa realizada em Piracicaba, recebeu dos alunos da zona urbana $34 \%$ das citações. Alimentos como o catchup $(0,4 \%)$, iogurtes $(1,2 \%)$, queijos $(5,5 \%)$ e requeijão $(1,5 \%)$, também receberam baixo número de citações pelos alunos de Piedade. Situação inversa ocorreu com a margarina, que recebeu $45,5 \%$ das citações.

A avaliação qualitativa sobre a freqüência do consumo de alimentos deixa clara a necessidade da implementação de estratégias de intervenção, entre elas os programas de educação nutricional dirigidos aos escolares, visto que, por exemplo, o consumo diário de frutas e hortaliças revelou-se muito baixo, e ainda, é possível que não estejam sendo aproveitados os recursos disponíveis, como é o caso da área em torno da casa (situada no meio rural) para o cultivo de frutas.

$\mathrm{Na}$ Tabela 10 é possível conhecer a participação dos diferentes grupos de alimentos no consumo total dos escolares, discriminando-os de acordo com o sexo. 
Tabela 10. Distribuição dos escolares de acordo com o sexo e a participação relativa dos grupos de alimentos, no consumo total de alimentos. Piedade - SP, 2000.

\begin{tabular}{lrr}
\hline \multirow{2}{*}{ Participação Relativa dos Grupos de Alimentos } & \multicolumn{2}{c}{ Escolares/Sexo } \\
& Masculino & Feminino \\
\hline Cereais, Pães, Tubérculos, Raízes & 31,05 & 29,43 \\
Hortaliças & 3,24 & 3,42 \\
Frutas & 5,49 & 5,29 \\
Leite e produtos lácteos & 17,4 & 18,67 \\
Carnes e ovos & 12,42 & 11,79 \\
Leguminosas & 9,08 & 8,09 \\
Óleos e gorduras e açúcares e doces* & 12,18 & 13,42 \\
Diversos** & 2,42 & 2,78 \\
Indeterminados (sem identificação de grupo) & 6,72 & 7,11 \\
Total & 100,00 & 100,00 \\
\hline * Os óleos, gorduras e açúcares que integram os alimentos não foram considerados nos cálculos. \\
** O grupo engloba preparações cujos ingredientes pertencem a dois ou mais grupos de alimentos \\
(exemplos: torta de frango, sopa de legumes, lasanha àbolonhesa, esfiha de queijo, entre outros). \\
*** O café, chá, adoçante e cogumelo foram considerados alimentos sem definição de grupo.
\end{tabular}

De acordo com a Tabela 10, verifica-se, quando se considera de forma geral o consumo de alimentos, resultados similares para escolares, de ambos os sexos. O grupo dos cereais, pães, tubérculos e raízes participaram, de maneira mais expressiva, conforme o previsto, no consumo de meninos $(31,05 \%)$, quando comparado com o valor registrado pelas meninas $(29,43 \%)$. Tal situação é decorrente da freqüência elevada das citações recebidas pelo arroz, biscoitos, macarrão, entre outros, conforme descrito anteriormente. Dentre os grupos de alimentos considerados fonte de proteínas, a maior proporção de participação, quando se considera escolares de ambos os sexos, recaem para o grupo do leite e produtos lácteos (terceiro alimento com o maior número de citações entre os alunos, de acordo com as análises descritas anteriormente), seguido das carnes e ovos e por último, o grupo das leguminosas (contendo somente o feijão), que ocupa o segundo lugar, entre os alimentos mais citados pelos alunos. Ao examinar os dados, observa-se um dado preocupante relativo à participação do grupo dos óleos e gorduras e açúcares e doces, no consumo 
alimentar de escolares de ambos os sexos. A participação do referido grupo é superior ao grupo das frutas, hortaliças e leguminosas. Quando se considera as carnes e ovos, a participação do referido grupo é maior para as alunas. Isto se deve principalmente à expressiva contribuição da margarina, açúcar refinado, refrigerantes e sucos artificiais quando se considera o consumo global de alimentos. Outro dado que merece atenção é o maior consumo, revelado pelos escolares (meninos e meninas), de alimentos classificados como Indeterminados (sem identificação de grupo), composto basicamente pelo café $(50,6 \%$ de citações), além do cogumelo $(0,2 \%)$, adoçante $(0,4 \%)$ e chá $(10,2 \%)$, quando se compara com os dados relativos ao grupo das frutas e hortaliças. O resultado corrobora as análises anteriores, que mostraram o forte hábito do consumo de café pelos alunos de Piedade. Além do mais, vários estudos envolvendo a população de municípios do interior de São Paulo, apontam para o baixo consumo de frutas e hortaliças entre crianças e adolescentes. Como exemplo podemos destacar o estudo de Castro (2001), que envolveu 46 escolares da zona urbana e 36 escolares da zona rural. Na referida pesquisa foi observado que, no tocante ao consumo de hortaliças, $62,2 \%$ do total de escolares $(n=82)$, não consumiram legumes e verduras, de acordo com o recomendado pelo Guia Alimentar da Pirâmide, que preconiza o consumo de 3 a 5 porções desse grupo por dia (equivalente a 1 xícara de folhas cruas, 1/2xícara de vegetais picados crus e/ou 3/4xícara suco de vegetais). Em relação às frutas, a maioria dos estudantes $(56,1 \%)$ informaram que não consumiam nenhuma porção (considera-se que uma porção equivale a 1 fruta média, 1/2xícara de frutas enlatadas ou cozidas e/ou 3/xícara de suco de frutas) ao dia.

Na pesquisa de Nuzzo (1998), foi observado, entre os escolares, que foi menor o consumo dos alimentos identificados na base da pirâmide alimentar (adaptada por Philippi et al. 1999b), e também, do grupo das hortaliças e frutas. Inversamente, verificou excesso de consumo de alimentos integrantes do ápice da pirâmide (compostos por óleos, gorduras e açúcares), ou seja, as guloseimas, doces, entre outros. 
Gambardella (1995) registrou em amostra de estudantes do período noturno, com idade entre 10 a 18 anos, em relação àinadequação da dieta (falta ou excesso) tendo por base análises por grupos de alimentos, que $63,8 \%$ das meninas que trabalhavam apresentaram um consumo inferior a duas porções para o grupo do leite. Em relação às frutas, o maior número de inadequação $(86,7 \%)$ foi observada para os meninos que trabalhavam, os quais consumiram menos de duas porções do referido grupo por dia. A mesma situação ocorreu quando se considerou a adequação do consumo do grupo das hortaliças. Os meninos revelaram dietas inadequadas $(75 \%)$ para o grupo das hortaliças, ou seja, um consumo inferior a duas porções por dia. É interessante destacar, em relação ao grupo do açúcar/gordura, que o consumo foi considerado adequado quando se considerou àingestão de uma porção, por dia, do grupo do açúcar ou do grupo da gordura.

De acordo com o referido autor, não foi identificada proporção de alunos na categoria de dieta considerada "inadequada", quando se analisou a situação relativa ao consumo insuficiente. No entanto, entre o grupo das meninas que trabalhavam (63,8\%), 38,3\% apresentaram excesso (inadequação) de consumo de alimentos integrantes do grupo que abriga tanto o açúcar como a gordura. 


\subsubsection{Análises quantitativas}

As análises quantitativas, tendo por base o consumo alimentar dos escolares, foram elaboradas avaliando-se o conteúdo energético e de nutrientes das dietas, mediante cálculos referentes aos macronutrientes (carboidratos, lipídeos totais e proteínas), colesterol, fibras totais, tiamina, riboflavina, niacina, vitamina $B_{6}$, vitamina $B_{12}$, folacina, vitamina $C$, vitamina $A$, vitamina $E$, cálcio, fósforo, ferro, zinco, selênio e cobre.

Visando facilitar as análises envolvendo o consumo dos escolares pertencentes à amostra e as recomendações preconizadas para o grupo, julgouse pertinente a inclusão dos Quadros 1 e 2, nesta seção da dissertação, apresentados a seguir. 


\begin{tabular}{|c|c|c|c|c|c|c|c|c|c|c|c|c|c|}
\hline & \multicolumn{13}{|c|}{ Idade (em anos) } \\
\hline Energia e nutrientes & 6 & 7 & 8 & 9 & 10 & 11 & 12 & 13 & 14 & 15 & 16 & 17 & 18 \\
\hline Energia $(\mathrm{kcal})$ * & 1800 & 2000 & 2000 & 2000 & 2000 & 2500 & 2500 & 2500 & 2500 & 3000 & 3000 & 3000 & 3000 \\
\hline Carboidratos $(\mathrm{g})^{* * *}$ & 270 & 300 & 300 & 300 & 300 & 375 & 375 & 375 & 375 & 450 & 450 & 450 & 450 \\
\hline Lipídeos $(\mathrm{g})^{* * *}$ & 60 & 67 & 67 & 67 & 67 & 83 & 83 & 83 & 83 & 100 & 100 & 100 & 100 \\
\hline Proteínas $(\mathrm{g})^{\star * *}$ & 45 & 50 & 50 & 50 & 50 & 62 & 62 & 62 & 62 & 75 & 75 & 75 & 75 \\
\hline Fibras $(\mathrm{g})^{* *}$ & 20 & 20 & 20 & 20 & 20 & 20 & 20 & 20 & 20 & 20 & 20 & 20 & 20 \\
\hline Colesterol $(\mathrm{mg})^{* \star}$ & 180 & 200 & 200 & 200 & 200 & 250 & 250 & 250 & 250 & 300 & 300 & 300 & 300 \\
\hline Vit. A $\left(\mu_{\mathrm{g}}\right)^{*}$ & 500 & 700 & 700 & 700 & 700 & 1000 & 1000 & 1000 & 1000 & 1000 & 1000 & 1000 & 1000 \\
\hline Vit. $E(m g)^{\star \star \star}$ & 7 & 7 & 7 & 11 & 11 & 11 & 11 & 11 & 15 & 15 & 15 & 15 & 15 \\
\hline Vit. C (mg) ${ }^{* * *}$ & 25 & 25 & 25 & 45 & 45 & 45 & 45 & 45 & 75 & 75 & 75 & 75 & 75 \\
\hline Vit. B1 $(\mathrm{mg})^{* \star *}$ & 0,6 & 0,6 & 0,6 & 0,9 & 0,9 & 0,9 & 0,9 & 0,9 & 1,2 & 1,2 & 1,2 & 1,2 & 1,2 \\
\hline Vit. B2 $(\mathrm{mg})^{* * *}$ & 0,6 & 0,6 & 0,6 & 0,9 & 0,9 & 0,9 & 0,9 & 0,9 & 1,3 & 1,3 & 1,3 & 1,3 & 1,3 \\
\hline Vitl B3 (mg) *** & 8 & 8 & 8 & 12 & 12 & 12 & 12 & 12 & 16 & 16 & 16 & 16 & 16 \\
\hline Vitl B6 (mg) *** & 0,6 & 0,6 & 0,6 & 1 & 1 & 1 & 1 & 1 & 1,3 & 1,3 & 1,3 & 1,3 & 1,3 \\
\hline Folacina $(\mu \mathrm{g})^{* * *}$ & 200 & 200 & 200 & 300 & 300 & 300 & 300 & 300 & 400 & 400 & 400 & 400 & 400 \\
\hline Vit. B12 $(\mu \mathrm{g})^{* * *}$ & 1,2 & 1,2 & 1,2 & 1,8 & 1,8 & 1,8 & 1,8 & 1,8 & 2,4 & 2,4 & 2,4 & 2,4 & 2,4 \\
\hline Cálcio $(\mathrm{mg})^{* \star *}$ & 800 & 800 & 800 & 1300 & 1300 & 1300 & 1300 & 1300 & 1300 & 1300 & 1300 & 1300 & 1300 \\
\hline Fósforo $(\mathrm{mg})^{\star \star \star}$ & 500 & 500 & 500 & 1250 & 1250 & 1250 & 1250 & 1250 & 1250 & 1250 & 1250 & 1250 & 1250 \\
\hline Ferro $(\mathrm{mg})$ * & 10 & 10 & 10 & 10 & 10 & 12 & 12 & 12 & 12 & 12 & 12 & 12 & 12 \\
\hline Zinco $(\mathrm{mg})$ * & 10 & 10 & 10 & 10 & 10 & 15 & 15 & 15 & 15 & 15 & 15 & 15 & 15 \\
\hline Selênio $(\mu \mathrm{g})^{* \star *}$ & 30 & 30 & 30 & 40 & 40 & 40 & 40 & 40 & 55 & 55 & 55 & 55 & 55 \\
\hline Cobre $(\mathrm{mg})$ * & $1,0-1,5$ & $1,0-2,0$ & $1,0-2,0$ & $1,0-2,0$ & $1,0-2,0$ & $1,5-2,5$ & $1,5-2,5$ & $1,5-2,5$ & $1,5-2,5$ & $1,5-3,0$ & $1,5-3,0$ & $1,5-3,0$ & $1,5-3,0$ \\
\hline
\end{tabular}

Quadro 1 - Recomendações de energia e nutrientes de acordo com a idade (em anos) dos escolares do sexo masculino.

$\left({ }^{*}\right)$ Recomendações definidas pela National Research Council - NRC (1989).

$\left({ }^{* \star}\right)$ Recomendações definidas pela Sociedade Brasileira de Alimentação e Nutrição - SBAN (1990)

$\left.{ }_{(* *}^{*}\right)$ Recomendações definidas pela National Academy of Sciences. Institute of Medicine. Food and Nutrition Board (2000) e (2002). 


\begin{tabular}{|c|c|c|c|c|c|c|c|c|c|c|c|c|c|}
\hline & \multicolumn{13}{|c|}{ Idade (em anos) } \\
\hline Energia e nutrientes & 6 & 7 & 8 & 9 & 10 & 11 & 12 & 13 & 14 & 15 & 16 & 17 & 18 \\
\hline Energia (kcal) * & 1800 & 2000 & 2000 & 2000 & 2000 & 2200 & 2200 & 2200 & 2200 & 2200 & 2200 & 2200 & 2200 \\
\hline Carboidratos $(\mathrm{g})^{\star * \star}$ & 270 & 300 & 300 & 300 & 300 & 330 & 330 & 330 & 330 & 330 & 330 & 330 & 330 \\
\hline Lipídeos $(\mathrm{g})^{\star \star \star}$ & 60 & 67 & 67 & 67 & 67 & 73 & 73 & 73 & 73 & 73 & 73 & 73 & 73 \\
\hline Proteínas $(\mathrm{g})^{* * *}$ & 45 & 50 & 50 & 50 & 50 & 55 & 55 & 55 & 55 & 55 & 55 & 55 & 55 \\
\hline Fibras $(\mathrm{g})^{* *}$ & 20 & 20 & 20 & 20 & 20 & 20 & 20 & 20 & 20 & 20 & 20 & 20 & 20 \\
\hline Colesterol $(\mathrm{mg})^{* *}$ & 180 & 200 & 200 & 200 & 200 & 220 & 220 & 220 & 220 & 220 & 220 & 220 & 220 \\
\hline Vit. A $(\mu \mathrm{g})^{*}$ & 500 & 700 & 700 & 700 & 700 & 800 & 800 & 800 & 800 & 800 & 800 & 800 & 800 \\
\hline Vit. $E(m g)^{* \star *}$ & 7 & 7 & 7 & 11 & 11 & 11 & 11 & 11 & 15 & 15 & 15 & 15 & 15 \\
\hline Vit. $C(m g)^{\star \star \star}$ & 25 & 25 & 25 & 45 & 45 & 45 & 45 & 45 & 65 & 65 & 65 & 65 & 65 \\
\hline Vit. B1 $(\mathrm{mg})^{* \star \star}$ & 0,6 & 0,6 & 0,6 & 0,9 & 0,9 & 0,9 & 0,9 & 0,9 & 1 & 1 & 1 & 1 & 1 \\
\hline Vit. B2 $(\mathrm{mg})^{\star \star \star \star}$ & 0,6 & 0,6 & 0,6 & 0,9 & 0,9 & 0,9 & 0,9 & 0,9 & 1 & 1 & 1 & 1 & 1 \\
\hline Vitl B3 (mg) *** & 8 & 8 & 8 & 12 & 12 & 12 & 12 & 12 & 14 & 14 & 14 & 14 & 14 \\
\hline Vitl B6 (mg) V $^{* \star *}$ & 0,6 & 0,6 & 0,6 & 1 & 1 & 1 & 1 & 1 & 1,2 & 1,2 & 1,2 & 1,2 & 1,2 \\
\hline Folacina $(\mu \mathrm{g})^{* * *}$ & 200 & 200 & 200 & 300 & 300 & 300 & 300 & 300 & 400 & 400 & 400 & 400 & 400 \\
\hline Vit. B12 $(\mu \mathrm{g})^{* * *}$ & 1,2 & 1,2 & 1,2 & 1,8 & 1,8 & 1,8 & 1,8 & 1,8 & 2,4 & 2,4 & 2,4 & 2,4 & 2,4 \\
\hline Cálcio $(\mathrm{mg})^{\star \star *}$ & 800 & 800 & 800 & 1300 & 1300 & 1300 & 1300 & 1300 & 1300 & 1300 & 1300 & 1300 & 1300 \\
\hline Fósforo $(\mathrm{mg})^{\star \star *}$ & 500 & 500 & 500 & 1250 & 1250 & 1250 & 1250 & 1250 & 1250 & 1250 & 1250 & 1250 & 1250 \\
\hline Ferro $(\mathrm{mg}) *$ & 10 & 10 & 10 & 10 & 10 & 15 & 15 & 15 & 15 & 15 & 15 & 15 & 15 \\
\hline Zinco $(\mathrm{mg})^{*}$ & 10 & 10 & 10 & 10 & 10 & 12 & 12 & 12 & 12 & 12 & 12 & 12 & 12 \\
\hline Selênio $(\mu \mathrm{g}) * * *$ & 30 & 30 & 30 & 40 & 40 & 40 & 40 & 40 & 55 & 55 & 55 & 55 & 55 \\
\hline Cobre $(\mathrm{mg})$ * & $1,0-1,5$ & $1,0-2,0$ & $1,0-2,0$ & $1,0-2,0$ & $1,0-2,0$ & $1,5-2,5$ & $1,5-2,5$ & $1,5-2,5$ & $1,5-2,5$ & $1,5-3,0$ & $1,5-3,0$ & $1,5-3,0$ & $1,5-3,0$ \\
\hline
\end{tabular}

Quadro 2 - Recomendações de energia e nutrientes de acordo com a idade (em anos) dos escolares do sexo feminino.

$\left({ }^{*}\right)$ Recomendações definidas pela National Research Council - NRC (1989).

$\left.{ }^{* \star}\right)$ Recomendações definidas pela Sociedade Brasileira de Alimentação e Nutrição - SBAN (1990)

${ }_{(* * *)}^{*}$ Recomendações definidas pela National Academy of Sciences. Institute of Medicine. Food and Nutrition Board (2000) e (2002). 
Os resultados da distribuição dos percentis de energia e nutrientes, obtidos junto aos escolares, são apresentados a seguir na Tabela11.

Tabela 11. Distribuição dos percentis do consumo de energia e nutrientes selecionados dos escolares. Piedade - SP, 2000.

\begin{tabular}{|c|c|c|c|c|c|}
\hline \multirow[b]{2}{*}{ Energia e nutrientes } & \multicolumn{5}{|c|}{ Percentis } \\
\hline & $10^{\circ} \mathrm{P}$ & $25^{\circ} \mathrm{P}$ & $50^{\circ} \mathrm{P}$ & $75^{\circ} \mathrm{P}$ & $90^{\circ} \mathrm{P}$ \\
\hline Energia (kcal) & 957,81 & 1198,18 & 1584,88 & 2003,11 & 2536,19 \\
\hline Proteínas (g) & 33,36 & 47,84 & 65,35 & 86,16 & 111,04 \\
\hline Carboidratos (g) & 119,24 & 155,33 & 200,13 & 256,83 & 326,55 \\
\hline Lipídeos totais (g) & 21,5 & 34,8 & 53,17 & 74,22 & 100,68 \\
\hline Colesterol (mg) & 49,36 & 101,08 & 180,23 & 255,88 & 344,92 \\
\hline Fibras totais (g) & 2,89 & 3,74 & 5,52 & 8,84 & 13,3 \\
\hline Tiamina (mg) & 0,42 & 0,59 & 0,84 & 1,21 & 1,67 \\
\hline Riboflavina (mg) & 0,43 & 0,69 & 0,99 & 1,38 & 1,88 \\
\hline Niacina (mg) & 5,47 & 7,5 & 10,57 & 14,98 & 20,83 \\
\hline Vitamina B6 (mg) & 0,67 & 0,96 & 1,4 & 1,95 & 2,63 \\
\hline Vitamina B12 $(\mu \mathrm{g})$ & 0,76 & 1,68 & 3,51 & 6,1 & 8,23 \\
\hline Folacina $(\mu \mathrm{g})$ & 60,3 & 85,21 & 114,04 & 147,06 & 185,78 \\
\hline Vitamina C (mg) & 4,25 & 8,6 & 18,73 & 51,28 & 94,53 \\
\hline Vitamina A $(\mu \mathrm{g})$ & 53,2 & 90,54 & 153,63 & 283,01 & 557,13 \\
\hline Vitamina $E(m g)$ & 2,83 & 4,3 & 5,83 & 7,78 & 10,3 \\
\hline Cálcio (mg) & 105,7 & 269,55 & 389,84 & 571,09 & 795,02 \\
\hline Fósforo (mg) & 543,06 & 724,99 & 990,88 & 1332,87 & 1654,09 \\
\hline Ferro (mg) & 5,33 & 7,23 & 10,15 & 13,29 & 17,18 \\
\hline Zinco (mg) & 3,46 & 5,23 & 7,34 & 9,28 & 11,95 \\
\hline Selênio $(\mu \mathrm{g})$ & 37,02 & 50,4 & 68,36 & 88,72 & 112,22 \\
\hline
\end{tabular}

Analisando os dados da Tabela 11 nota-se que o valor $(957,81 \mathrm{kcal})$ que separa os $10 \%$ dos escolares, que apresentaram o menor consumo de energia, é baixo, não alcançando $50 \%$ do recomendado. Não sobram dúvidas que o referido conteúdo energético é muito inferior ao preconizado (média de $2300 \mathrm{kcal}$ ) para o grupo (NRC, 1989). Portanto, os escolares submetidos à dieta com tal característica, merecem atenção especialmente no que se refere ao acompanhamento do estado nutricional.

Vale lembrar que na seção dedicada à análise do estado nutricional, foi mostrado que $22,1 \%$ dos escolares foram classificados com IMC $<15^{\circ} \mathrm{P}$, ou 
seja, considerados de baixo peso. Note-se que em população, adotada como referência, espera-se encontrar $15 \%$ de indivíduos nessa condição.

Situação inversa é observada quando se considera o menor conteúdo de energia consumido pelos $10 \%$ dos escolares com dieta de maior valor energético. Note-se que $10 \%$ desses alunos consomem no mínimo 2536,19kcal.

A situação do consumo energético dos escolares da presente pesquisa é semelhante aos dados encontrados por Caroba (2002), tendo como base amostra de adolescentes com idade entre 11 e 16 anos, residentes no município de Piracicaba. O referido autor verificou um consumo máximo de 991,7kcal entre os $10 \%$ de escolares com menor consumo de energia e, para o grupo de alunos que revelaram maior consumo de energia, o conteúdo de energia superou 2916,0kcal.

Quando se analisou a prevalência de sobrepeso, entre os escolares (IMC $\geq 85^{\circ} \mathrm{P}$ ), proporção abaixo da esperada (15\%) foi observada ( $n=32$ ou $10 \%$ ).

Quanto ao consumo de proteína, vale destacar que $50 \%$ da população observada consome quantidade superior a 65,35g/dia. Trata-se de valor considerado elevado, especialmente quando se considera a quantidade (média) preconizada (57g) para o grupo (National Academy of Sciences, 2002).

Silva (1996) implementando pesquisa envolvendo amostra de 257 escolares com idade entre 7 e 13 anos, verificou em relação ao consumo protéico, um atendimento para todo o grupo analisado que superava $100 \%$ das recomendações. O autor destacou também que a problemática alimentar, quando existente, em todas as regiões brasileiras, é de origem quantitativa, sendo a deficiência energética mais freqüente do que a protéica.

Priore (1996) analisando dados de uma amostra de 95 adolescentes, com idade entre 10 e 13 anos, residentes em favelas de São Paulo, verificou em relação ao conteúdo energético das dietas provenientes das proteínas, que mais de $90 \%$ dos adolescentes consumiram no mínimo a quantidade esperada. $O$ autor registra, também, que o problema alimentar da população, integrante da pesquisa, "não era basicamente protéico". 
Merecem atenção os dados, obtidos entre os escolares de Piedade, relativos ao consumo de colesterol, pois é possível verificar que $25 \%$ dos alunos consumiram no mínimo $180,23 \mathrm{mg} /$ dia. Nota-se também que $10 \%$ dos alunos ingeriram quantidade superior a 344,92mg/dia, valor muito maior do que a quantidade máxima desejável de 300mg (Vannucchi et al., 1990). Ressalta-se que o colesterol não é um nutriente que deve necessariamente ser incluído na alimentação, não sendo, também, considerado essencial, pois o organismo pode sintetizá-lo em quantidades adequadas.

Atenção deve ser dedicada, também, aos resultados obtidos para o consumo de fibras, folacina e cálcio, pois $90 \%$ dos alunos ingeriram quantidades que não atendem as recomendações nutricionais preconizadas para o grupo. Vale lembrar que, para o referido grupo, as recomendações diárias (média) de fibras, folacina e cálcio são $20 \mathrm{~g}$, 300 $\mu \mathrm{g}$ e $1050 \mathrm{mg}$, respectivamente (Vannucchi et al., 1990; National Academy of Sciences, 2000).

Os resultados obtidos nesta pesquisa são preocupantes, uma vez que reflete um consumo inadequado de fibras, que provavelmente seja decorrente de baixa quantidade de consumo, pelos escolares, de frutas e hortaliças, fontes de fibras totais (solúveis e insolúveis). No entanto cabe lembrar que análises apresentadas anteriormente revelaram que a freqüência de citação do consumo de hortaliças pelos escolares é substancial, o mesmo não ocorrendo com o registro observado para as frutas. Pesquisa, desenvolvida por Caroba (2002), identificou que $90 \%$ dos escolares consumiam quantidade de fibras inferior a $21,5 \mathrm{~g}$, enquanto a recomendação é de $20 \mathrm{~g} /$ dia (Vannucchi et al.,1990).

$O$ consumo adequado de fibras durante a infância e a adolescência repercutirão beneficamente para a saúde dos indivíduos quando alcançarem a idade adulta, devido ao seu efeito protetor contra as doenças cardiovasculares, obesidade, diabetes não-insulino-dependente, hipertensão, doenças do cólon e câncer (Giovannini et al., 1996).

De particular interesse, quando se considera o consumo de fibras, são os resultados da pesquisa conduzida por Bernard et al. (1995) que, ao analisarem 
os dados relativos à crianças e adolescentes com sobrepeso, verificaram que os mesmos consumiam porções substancialmente menores de frutas e vegetais (fonte de fibras), quando comparadas æ̀ porções dos referidos alimentos, ingeridas pelos grupos de crianças e adolescentes eutróficos.

Em relação ao cálcio, sabe-se que é um nutriente muito importante para a maturação óssea das crianças e adolescentes, atuando preventivamente contra as doenças como o raquitismo, além de promover, juntamente com outros nutrientes, um adequado crescimento (Mahan \& Arlin, 1994). Note-se que, entre os alunos da rede pública de ensino de Piedade, 90\% revelaram dieta cujo conteúdo de cálcio se revelou muito baixo. Tendo em vista as importantes funções desempenhadas pelo cálcio no organismo humano, os escolares da presente pesquisa merecem atenção especial para que sejam evitados prejuízos causados pelo déficit de consumo de cálcio, principalmente entre as meninas que têm maior probabilidade de desenvolver osteoporose quando alcançarem a idade adulta.

A folacina revela-se essencial para a formação e maturação das hemáceas e leucócitos na medula óssea. Sua deficiência pode resultar em déficit de crescimento, anemia megaloblástica, glossites, distúrbios no trato gastrointestinal, entre outros prejuízos à saúde (Mahan \& Arlin, 1994). Tais conseqüências determinadas pelo consumo inadequado de folacina reforçam a importância da intervenção nutricional entre os escolares de Piedade, especialmente quando se considera os resultados da Tabela 11, que mostra $90 \%$ dos escolares com consumo que não alcança o valor recomendado.

Ao examinar os dados da Tabela 11, chama a atenção o baixo consumo da vitamina A e, também, do zinco, pois $90 \%$ dos alunos consumiram quantidades inferiores à preconizadas pela NRC (1989), ou seja, média de $800 \mu \mathrm{g}$ de vitamina A e $12 \mathrm{mg}$ de zinco. Segundo Mahan \& Arlin (1994), a vitamina $A$ desempenha papel essencial para a integridade da visão, para o crescimento ósseo, manutenção do tecido epitelial, no processo imunitário, entre outras funções. 
O zinco desempenha funções importantes no organismo humano e sua deficiência pode causar retardo no crescimento e prejuízos na maturação sexual de crianças e adolescentes, além de desempenhar outros papéis importantes, entre os quais merece destaque, a taxa de regulação para a expressão de genes específicos (Haschke \& Male, 1996).

A vitamina A designa um grupo de compostos essenciais à visão, crescimento, diferenciação e proliferação celular, reprodução e integridade do sistema imunológico. A deficiência de vitamina A pode ocasionar xeroftalmia, perda de apetite, maior susceptibilidade às infecções, entre outros distúrbios (NRC, 1989).

Outros valores que merecem ser destacados referem-se ao ferro e à vitamina C. Verifica-se que $75 \%$ dos escolares consomem quantidades inferiores a $13,29 \mathrm{mg}$ e $51,28 \mathrm{mg}$, de ferro e vitamina $\mathrm{C}$, respectivamente. É oportuno lembrar que a recomendação média diária para o ferro é $23 \mathrm{mg}$ e para a vitamina C, 46mg (NRC, 1989; National Academy of Sciences, 2000). A deficiência do consumo de ferro constitui-se em um fator de risco para o desenvolvimento da anemia ferropriva. Esse risco poderá ser aumentado, associado concomitantemente à de ficiência do consumo de vitamina $C$ que possui, entre outras funções, a capacidade de aumentar a absorção do ferro não-heme presente nos alimentos de origem vegetal.

De acordo com Vannucchi et al. (1992) apesar da anemia constituir-se em problema de saúde pública em todo o mundo, com prejuízos para a saúde principalmente da população dos países em desenvolvimento, ainda são poucos e dispersos os estudos conclusivos sobre esta deficiência. Segundo os referidos autores, a deficiência de ferro é responsável por $90 \%$ dos casos de anemia e a diminuição de sua ingestão pode ser condicionada por erro alimentar e ainda por carência alimentar. Em nosso meio a carência alimentar é mais freqüentemente observada devido æ̀ condições sociais e econômicas de substancial pa rcela da população. Invariavelmente, as referidas condições contribuem para uma dieta 
deficiente (quantitativa e qualitativamente), não somente no que diz respeito ao ferro, mas também quando se considera outros nutrientes essenciais.

Priore (1996) avaliando o conteúdo de ferro das dietas de 95 adolescentes, constatou que $26,1 \%$ dos integrantes da amostra possuíam dietas com teores de ferro menores ao valor correspondente a $90 \%$ das recomendações propostas pela NRC (1989).

A vitamina $E$, considerada nutriente importante pela sua ação antioxidante contra os radicais livres, em atuação conjunta com o selênio, se revelou pouco presente na dieta da maioria dos escolares, ou seja, média de $11 \mathrm{mg}$ por dia (National Academy of Sciences, 2000). Note-se que 75\% dos escolares apresentaram consumo inferior a 7,78mg da referida vitamina.

A distribuição dos percentis do consumo de selênio revela $50 \%$ da população analisada com consumo do mineral acima $(68,36 \mu \mathrm{g})$ da quantidade média diária $(41,6 \mu \mathrm{g})$ preconizada para o grupo (National Academy of Sciences, 2000). Ressalta-se que $90 \%$ da população apresentou um consumo mínimo de $112,22 \mu \mathrm{g}$, quantidade que é praticamente o dobro do valor médio registrado para o grupo.

O selênio e a vitamina $E$ têm ação mútua como antioxidantes. O selênio age com o tocoferol para proteger a célula e as organelas da membrana contra danos oxidativos. O selênio também contribui para a síntese de imunoglobulinas, além de participar intensamente em outras funções (Mahan \& Arlin, 1994).

Visando conhecer as distribuições dos percentis do consumo de energia e nutrientes, de acordo com o sexo, elaborou-se a Tabela 12, apresentada a seguir. 
Tabela 12. Distribuição dos percentis de consumo de energia e nutrientes selecionados, de acordo com o sexo dos escolares. Piedade - SP, 2000.

\begin{tabular}{|c|c|c|c|c|c|c|c|c|c|c|}
\hline \multirow{3}{*}{ Energia e nutrientes } & \multicolumn{8}{|c|}{ Percentis/Sexo } & \multirow{2}{*}{\multicolumn{2}{|c|}{$90^{\circ} \mathrm{P}$}} \\
\hline & \multicolumn{2}{|c|}{$10^{\circ} \mathrm{P}$} & \multicolumn{2}{|c|}{$25^{\circ} \mathrm{P}$} & \multicolumn{2}{|c|}{$50^{\circ} \mathrm{P}$} & \multicolumn{2}{|c|}{$75^{\circ} \mathrm{P}$} & & \\
\hline & $\mathrm{M}$ & $\mathrm{F}$ & $M$ & $\mathrm{~F}$ & $M$ & $\mathrm{~F}$ & $M$ & $\mathrm{~F}$ & $\mathrm{M}$ & $\mathrm{F}$ \\
\hline Energia (kcal) & 1002,01 & 910,95 & 1221,60 & 1187,10 & 1602,71 & 1542,54 & 2005,84 & 1982,60 & 2506,64 & 2548,05 \\
\hline Proteínas (g) & 33,36 & 31,73 & 49,19 & 46,67 & 69,03 & 63,46 & 88,60 & 84,62 & 112,59 & 111,04 \\
\hline Carboidratos (g) & 123,42 & 117,38 & 164,55 & 150,67 & 200,62 & 198,92 & 256,64 & 257,02 & 329,69 & 326,08 \\
\hline Lipídeos totais (g) & 21,17 & 21,74 & 35,03 & 34,49 & 54,73 & 51,22 & 75,45 & 72,31 & 98,25 & 101,93 \\
\hline Colesterol (mg) & 45,28 & 53,45 & 101,58 & 100,78 & 176,28 & 185,77 & 244,17 & 259,56 & 340,72 & 346,62 \\
\hline Fibras totais $(\mathrm{g})$ & 2,94 & 2,83 & 3,74 & 3,77 & 5,37 & 5,59 & 8,53 & 8,93 & 13,39 & 13,30 \\
\hline Tiamina $(\mathrm{mg})$ & 0,43 & 0,42 & 0,62 & 0,58 & 0,86 & 0,80 & 1,23 & 1,19 & 1,67 & 1,74 \\
\hline Riboflavina (mg) & 0,43 & 0,44 & 0,71 & 0,69 & 0,97 & 0,99 & 1,35 & 1,46 & 1,88 & 1,89 \\
\hline Niacina $(\mathrm{mg})$ & 5,47 & 5,30 & 7,78 & 7,25 & 10,74 & 10,39 & 14,98 & 14,97 & 20,38 & 21,60 \\
\hline Vitamina $B_{6}(m g)$ & 0,64 & 0,73 & 0,94 & 0,99 & 1,39 & 1,43 & 1,87 & 2,01 & 2,61 & 2,64 \\
\hline Vitamina $\mathrm{B}_{12}(\mu \mathrm{g})$ & 0,87 & 0,68 & 1,84 & 1,52 & 3,75 & 3,25 & 6,38 & 6,00 & 8,51 & 8,18 \\
\hline Folacina $(\mu \mathrm{g})$ & 59,14 & 60,76 & 91,11 & 80,57 & 115,29 & 112,65 & 149,74 & 144,84 & 179,05 & 186,96 \\
\hline Vitamina C (mg) & 3,89 & 5,20 & 7,66 & 9,08 & 17,92 & 18,90 & 51,35 & 50,99 & 86,66 & 99,52 \\
\hline Vitamina A $(\mu \mathrm{g})$ & 43,20 & 64,40 & 84,32 & 101,70 & 138,70 & 172,51 & 249,34 & 307,16 & 502,26 & 597,18 \\
\hline Vitamina $E(\mathrm{mg})$ & 2,87 & 2,66 & 4,27 & 4,31 & 6,07 & 5,70 & 7,55 & 7,97 & 10,33 & 10,21 \\
\hline Cálcio (mg) & 98,22 & 115,48 & 241,50 & 277,63 & 383,72 & 397,56 & 538,89 & 582,09 & 761,88 & 806,90 \\
\hline Fósforo (mg) & 560,50 & 514,63 & 727,43 & 722,54 & 1036,30 & 953,47 & 1329,81 & 1346,37 & 1618,24 & 1670,90 \\
\hline Ferro (mg) & 5,49 & 5,05 & 7,68 & 7,06 & 10,34 & 9,94 & 13,78 & 12,89 & 17,35 & 16,91 \\
\hline Zinco (mg) & 3,92 & 3,19 & 5,57 & 4,91 & 7,45 & 7,21 & 9,14 & 9,63 & 11,42 & 12,42 \\
\hline Selênio $(\mu \mathrm{g})$ & 40,08 & 36,02 & 55,34 & 48,40 & 70,19 & 66,22 & 89,02 & 87,28 & 116,03 & 110,27 \\
\hline Cobre (mg) & 0,60 & 0,60 & 0,83 & 0,85 & 1,27 & 1,19 & 1,77 & 1,69 & 2,20 & 2,35 \\
\hline
\end{tabular}


De uma forma geral, quando são analisados os dados relativos à distribuição de energia, verifica-se que as meninas apresentam menor consumo, se comparado com o conteúdo ingerido pelos meninos.

Vale ressaltar que $75 \%$ das meninas não consumiram dietas cujo conteúdo energético alcançasse $2000 \mathrm{kcal}$. Esse valor revela-se inferior aos preconizados pela NRC (1989) para a maioria do grupo (média de $2300 \mathrm{kcal}$ ), que integra a amostra.

Kazapi et al. (2001) analisaram o consumo de energia da amostra composta por 797 adolescentes matriculados em escolas públicas e privadas do município de Florianópolis - SC. Os autores observaram que aproximadamente $50 \%$ dos adolescentes apresentaram consumo energético insuficiente. A insuficiência energética foi mais prevalente entre as meninas $(57,88 \%)$ enquanto entre os meninos, alcançou cerca de $47 \%$.

Segundo Vannucchi et al. (1990) a insuficiente ingestão de energia por período prolongado pode ocasionar déficit de crescimento ou comprometimento da atividade física, com conseqüente diminuição da capacidade de aprendizagem. Inversamente, o excessivo consumo energético resulta em aumento de peso e na incidência de hipertensão arterial, aterosclerose, entre outras doenças.

Yuyama et al. (2000) ressaltam que a deficiência de energia na alimentação representa um grave problema nutricional, visto que 0 não atendimento das necessidades, devido à insuficiente ingestão de energia, dificulta a manutenção do aproveitamento adequado dos demais nutrientes essenciais. Citam como exemplo o desvio da proteína de sua função primordial (utilização plástica) para indevidamente atender as demandas energéticas.

Ainda de acordo com a Tabela 12, a distribuição dos percentis do consumo de proteína revelaram-se muito semelhantes para os escolares de ambos os sexos. Invariavelmente, as meninas apresentaram um menor consumo protéico, observado por exemplo, quando se analisa o valor referente ao $10^{\circ} \mathrm{P}$ que registra $33,36 \mathrm{~g}$ de proteína consumida pelos $10 \%$ dos alunos, com 
menor consumo desse macronutriente. No entanto, cabe ressaltar que o consumo protéico (cerca de $66 \mathrm{~g}$ ) observado no $50^{\circ} \mathrm{P}$, supera a quantidade necessária para atender o grupo analisado. Note-se que para os meninos, foi observado consumo de $69,03 \mathrm{~g}$, enquanto valor discretamente inferior $(63,46 \mathrm{~g})$ foi identificado para as jovens.

Sichieri (1998), descrevendo resultados obtidos por meio de pesquisa desenvolvida no Rio de Janeiro, envolvendo amostra de adolescentes, com idade entre 12 e 18 anos, mostrou que o consumo médio de proteínas foi muito superior ao estipulado pela NRC (1989). De acordo com o autor, a quantidade de proteína recomendada para os adolescentes da pesquisa era de $45 \mathrm{~g} / \mathrm{dia}$ e os valores observados situaram-se ao redor de 100 $\mathrm{g} / \mathrm{dia}$, quantidade considerada exagerada para o grupo.

Ainda com base na Tabela 12, nota-se que de forma geral o consumo de colesterol revelado pelas meninas supera os valores observados para os meninos. É interessante destacar que $75 \%$ das garotas consumiram quantidades de colesterol inferior a $259,56 \mathrm{mg}$, enquanto igual proporção $(75 \%)$ de meninos apresentou consumo que não alcança $244,17 \mathrm{mg}$.

Surpreendente também são os valores relativos ao consumo do grupo dos $10 \%$ dos alunos, de ambos os sexos, que revelaram maior ingestão, ou seja, quantidade acima dos valores $340,72 \mathrm{mg}$ e $346,62 \mathrm{mg}$, observados para os meninos e meninas, respectivamente.

Em relação à distribuição do consumo lipídico, registra -se que $90 \%$ dos meninos e, também as meninas, consumiram quantidade mínima de 98,25g e $101,93 \mathrm{~g}$, respectivamente. Cabe salientar que estas quantidades superam a média de $75 \mathrm{~g}$ preconizada para o grupo (National Academy of Sciences, 2002).

Um estudo conduzido por Moura \& Sonati (1998), visando a avaliação do perfil lipídico das dietas dos escolares, analisou a relação entre os valores encontrados e o colesterol plasmático, obtendo associação positiva entre hipercolesterolemia e o percentual (33) de calorias proveniente dos triglicerídeos, sendo esses últimos divididos em ácidos graxos monoinsaturados, 
poliinsaturados e saturados. Ainda de acordo com os autores, as dietas dos escolares apresentaram as seguintes percentagens de contribuição: 12,0\% (ácidos graxos monoinsaturados), 8,5\% (ácidos graxos poliinsaturados) e 12,5\% (ácidos graxos saturados). Os autores também registraram que 22\% das crianças apresentaram colesterol plasmático acima de $170 \mathrm{mg} / \mathrm{dl}$ (valor recomendado pelo Instituto Nacional de Saúde). Os níveis de colesterol no plasma de $16,8 \%$ dos escolares alcançaram $185 \mathrm{mg} / \mathrm{dl}$ enquanto $4,8 \%$, dos integrantes da amostra, apresentaram $200 \mathrm{mg} / \mathrm{dl}$.

Nuzzo (1998), realizando pesquisa envolvendo amostra de adolescentes, verificou que a contribuição dos lipídeos para o valor energético total das dietas dos escolares do sexo masculino apresentou participação ligeiramente maior (entre $32 \%$ e $38 \%$ ) que a encontrada para as meninas (entre $32 \%$ e $36 \%$ ).

Johnson et al. (1994) implementaram pesquisa envolvendo amostra de 1392 crianças, com idade entre 1 e 10 anos e identificaram que $72,7 \%$ das crianças mais velhas (7 a 10 anos) apresentaram consumo adequado de colesterol (300mg ou menos). Entre as crianças com idade de 4 a 6 anos, $82,7 \%$ apresentaram ingestão adequada do referido nutriente. No entanto o referido percentual foi menor ao verificado $(89,0 \%)$ para as crianças de 1 a 3 anos de idade.

A situação observada na presente pesquisa, relativa ao consumo de fibras entre os escolares de ambos os sexos, pode ser considerada bastante desfavorável, pois $50 \%$ dos alunos consomem (em média), no máximo, $5,48 \mathrm{~g} /$ dia. O conteúdo de fibras consumido por $90 \%$ da população, embora mais alto (média de 13,3g/dia) também não chega a atingir as recomendações (20g/dia) definidas para o grupamento (Vannucchi et al., 1990).

Segundo Angelis (2000a) as fibras foram reconhecidas como componentes da dieta que assumem especial importância para a prevenção de distúrbios do trato digestivo, principalmente para diverticulites, hemorróidas, constipação intestinal, assim como na prevenção de diabetes e doenças cardiovasculares. 
Ortega et al. (1995) registraram um consumo inadequado de fibras entre 64 adolescentes espanhóis, com idade entre 15 e 17 anos. Os referidos autores verificaram que o consumo (médio) diário de fibras entre os adolescentes, classificados com sobrepeso ou obesidade, alcançou $15,9 \mathrm{~g}$ e para os adolescentes eutróficos, o consumo revelou-se mais elevado $(18,4 \mathrm{~g})$ de fibras.

Ainda de acordo com a Tabela 12, os dados relativos aos percentis do consumo de selênio, de forma geral, revelam que a quantidade ingerida pelas meninas é menor. No entanto, vale registrar que o consumo de $50 \%$ da população observada alcança, aproximadamente, $69 \mu \mathrm{g}$. O conteúdo observado atende as necessidades nutricionais de todo o grupamento analisado. Ainda em relação ao selênio, destaca-se que $90 \%$ da população consumiu valores acima

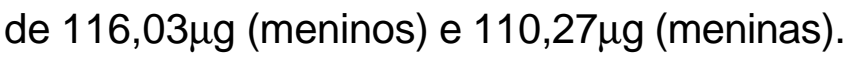

Yuyama et al. (2000), avaliando quantitativamente a dieta de 109 préescolares dos municípios Barcelos e Ajuricaba no Estado do Amazonas, verificaram, também, elevado consumo de selênio, entre os indivíduos integrantes da amostra. Os alunos apresentaram consumo médio de 58mg, valor considerado superior à recomendação nutricional estabelecida para a população analisada.

A análise da distribuição dos percentis do consumo de vitamina $E$ mostrou que $50 \%$ dos meninos $(6,07 \mathrm{mg})$ e meninas $(5,7 \mathrm{mg})$ consumiram quantidades reduzidas do nutriente. Mesmo quando se analisa os dados relativos aos $10 \%$ de escolares que mais ingeriram a vitamina, os valores encontrados de $10,33 \mathrm{mg}$ para os meninos e $10,21 \mathrm{mg}$ para as meninas, ainda se mostram insuficientes para o atendimento das necessidades nutricionais da maioria da população analisada.

Ortega et al. (1995) avaliando o padrão alimentar de 64 adolescentes espanhóis, com idade entre 15 e 17 anos, identificaram que mais da metade da população apresentou ingestão de vitamina $E$ inferior à preconizada para o grupamento etário. 
A importância da vitamina E na alimentação, segundo Barbieri (2000), refere-se a sua ação antioxidante, com a capacidade de impedir a fácil oxidação dos componentes lipídicos das membranas celulares decorrentes da ação dos radicais livres.

A análise dos dados relativos ao consumo do zinco, obtidos na presente pesquisa, se revelam reduzidos para os escolares de ambos os sexos. Entre a população observada, $75 \%$ consumiu quantidade inferior a $9,14 \mathrm{mg}$, quando se analisa a ingestão dos escolares e 9,63mg, quando se examina os dados obtidos para as alunas. Para os $10 \%$ da população que mais consumiu zinco, foi possível observar que os valores eram superiores a 11,42mg e 12,42mg, para meninos e meninas, respectivamente.

Os dados relativos à distribuição dos percentis do consumo de vitamina $\mathrm{C}$ registram, de forma surpreendente, que $75 \%$ da população consumiu quantidade da vitamina que não alcança a média de $52 \mathrm{mg}$ por dia. No entanto, quando se considera os $10 \%$ dos meninos e meninas que revelaram maior consumo de vitamina C, são observados valores superiores a $86,66 \mathrm{mg}$ e 99,52mg.

De acordo com Angelis (2000c), o consumo diário adequado de vitamina C é muito importante, pois trata-se de uma vitamina hidrossolúvel e portanto não é armazenada pelo organismo, sendo excretada diariamente, especialmente através da urina.

Ainda tendo por base os dados da Tabela 12, observa-se que o consumo de ferro se mostrou, invariavelmente maior, para os meninos. No entanto, revelou-se inadequado para $50 \%$ da população observada (conteúdo das dietas: $10,34 \mathrm{mg}$ para os meninos e $9,94 \mathrm{mg}$ para as meninas). Note-se que para o grupo dos $10 \%$ da amostra, com maior consumo do mineral, revelaram dieta contendo concentrações elevadas (valores acima de $17,35 \mathrm{mg}$ e $16,91 \mathrm{mg}$ para meninos e meninas, respectivamente).

Sichieri et al. (1996) desenvolvendo pesquisa, envolvendo estudantes brasileiros, com idade entre 6 e 12 anos, pertencentes a uma comunidade rural do Paraná, encontrou prevalência de anemia de $31,5 \%$ e $20,9 \%$, entre os 
meninos e meninas, respectivamente. A ingestão energética observada também se revelou baixa, com média diária de aproximadamente $1.100 \mathrm{kcal}$, para ambos os sexos. Segundo os referidos autores, a ingestão adequada de ferro e vitamina $C$ foi observada somente em $25 \%$ da população.

Lerner (1994), analisando dados relativos aos adolescentes de escolas públicas de Osasco, registrou que o consumo de ferro total foi inadequado para mais de $55 \%$ da população, sendo que entre os $5,3 \%$ de alunos anêmicos, todos revelaram consumo inadequado de ferro.

$\mathrm{Na}$ adolescência, o acelerado crescimento aumenta as necessidades de ferro, e ainda no caso das meninas, há de se considerar também as perdas adicionais impostas durante o período menstrual. A maior demanda do referido mineral pelo organismo feminino, assim como a tendência de menor consumo devido a adesão às "dietas especiais", quando comparado ao observado entre os meninos, explica, em parte, as razões pelas quais a deficiência de ferro entre as meninas parece aumentar durante o período da adolescência (Haschke \& Male, 1996).

Albano (2000) em pesquisa com adolescentes observou um consumo de ferro elevado para os meninos, superando em cerca de $110 \%$ as recomendações. Para o sexo feminino, o consumo médio atendeu $80,89 \%$ das recomendações preconizadas pela NRC (1989).

Causa preocupação os dados de consumo da vitamina $A$, registrado para os escolares de Piedade, pois revelam que $75 \%$ da população de meninos consumiu quantidade inferior a $249,34 \mu \mathrm{g}$ e igual proporção (75\%) das meninas possuíam dietas cujo conteúdo foi de $307,16 \mu \mathrm{g}$. Infelizmente a situação se revela pouco favorável também para os $10 \%$ da população com dietas que apresentaram maior conteúdo de vitamina A. Nesse caso o consumo mínimo observado foi de $502,26 \mu \mathrm{g}$ para os meninos e $597,18 \mu \mathrm{g}$ para as meninas.

Ruiz (1998) relatando resultados de pesquisa desenvolvida, tendo por base os dados relativos a 316 alunos, matriculados em escolas particulares de São Paulo, mostrou que a deficiência de vitamina $A$ foi elevada $(50 \%$ entre as 
meninas e $64 \%$ entre os meninos). Em relação ao ferro, $52 \%$ das meninas apresentaram deficiência desse mineral. Em contrapartida, somente 9\% dos meninos revelaram dietas inadequadas. Segundo o referido autor, o maior déficit de ferro observado quando se analisou as dietas das garotas pode ser atribuído ao fato de $41 \%$ delas, no passado, terem aderido aos regimes e/ou ainda manterem esta prática.

Ortega et al. (1995) identificaram em amostra de adolescentes, com idade entre 15 a 17 anos, que a média de ingestão diária de vitamina $A$ foi inadequada (consumo médio diário de $830 \mu \mathrm{g}$ ) para a totalidade dos integrantes da pesquisa.

De acordo com a Tabela 12, a distribuição dos percentis do consumo de cálcio, entre os escolares de Piedade, revela, invariavelmente, quantidade superior para as meninas. No entanto, $50 \%$ da população observada consumiu quantidade muito baixa $(383,72 \mathrm{mg}$ para os meninos e $397,56 \mathrm{mg}$ para as meninas). Mesmo quando se considera os $10 \%$ da população com maior consumo de cálcio, os valores não são animadores, pois o consumo mínimo registrado foi de $761,88 \mathrm{mg}$ (meninos) e $806,9 \mathrm{mg}$ (meninas). Vale lembrar que a recomendação média do referido nutriente é de 1050mg (National Academy of Sciences, 2000).

Lerner (2000) analisando o consumo de cálcio de 323 adolescentes pertencentes às escolas públicas do município de Osasco, registrou que somente $6,2 \%$ dos rapazes e 2,8\% das garotas apresentaram consumo de cálcio superior a $1200 \mathrm{mg} / \mathrm{dia}$. Segundo o referido autor, o leite (rico em cálcio) foi o alimento mais citado pelos adolescentes. No entanto, as meninas ingeriram cerca de $190 \mathrm{ml}$ de leite por dia, enquanto os meninos, $240 \mathrm{ml}$. O autor conclui que o consumo de cálcio entre os adolescentes é muito inferior às recomendações nutricionais definidas para o grupo.

Segundo Ruiz (1998), dos 316 estudantes de escolas particulares de São Paulo, $70 \%$ das meninas e $60 \%$ dos meninos ingeriram menor quantidade de cálcio recomendada para a idade e sexo. Tal comportamento poderá prejudicar 
o crescimento, além de contribuir para que os ossos e dentes se tornem mais frágeis.

Pesquisa de Sichieri (1998), envolvendo adolescentes com idade entre 12 e 18 anos, visando analisar o consumo de micronutrientes, revelou que os indivíduos de ambos os sexos apresentaram consumo abaixo do recomendado, principalmente quando se analisou a vitamina $A$, cálcio e ferro. O déficit se revelou mais relevante principalmente para as meninas com idade entre 15-18 anos. Entre esse grupo, mais da metade (55,6\%) apresentou consumo inadequado.

Visando descrever a participação dos macronutrientes no valor energético total - VET da dieta dos alunos integrantes da amostra, foram elaborados cálculos adotando-se como referência os intervalos estabelecidos pela National Academy of Sciences (2002): 45\%-65\% (carboidratos), 25\%-35\% (lipídeos) e $10 \%-30 \%$ (proteínas). Vale destacar que somente foram classificadas como adequadas as dietas cuja participação da totalidade dos macronutrientes (carboidratos, lipídeos e proteínas), incluíam-se nos intervalos.

A Tabela 13, apresentada a seguir, reúne os resultados referentes à participação dos macronutrientes na dieta, de acordo com o sexo dos escolares.

Tabela 13. Distribuição dos escolares de acordo com a participação dos macronutrientes na dieta e o sexo. Piedade - SP, 2000.

\begin{tabular}{|c|c|c|c|c|c|c|}
\hline \multirow{3}{*}{$\begin{array}{c}\text { Participação dos } \\
\text { macronutrientes na dieta }\end{array}$} & & & \multicolumn{4}{|c|}{ Sexo } \\
\hline & \multicolumn{2}{|c|}{ Observações } & \multicolumn{2}{|c|}{ Masculino } & \multicolumn{2}{|c|}{ Feminino } \\
\hline & № & $\%$ & № & $\%$ & № & $\%$ \\
\hline Adequada & 176 & 34,65 & 84 & 35,15 & 92 & 34,20 \\
\hline Inadequada & 332 & 65,35 & 155 & 64,85 & 177 & 65,80 \\
\hline Total & 508 & 100,00 & 239 & 100,00 & 269 & 100,00 \\
\hline
\end{tabular}


Tendo por base os dados da Tabela 13, verifica-se homogeneidade, quando se considera os resultados observados para os escolares de ambos os sexos. Aproximadamente $35 \%$ dos meninos e $34 \%$ das meninas consomem dietas classificadas como adequadas. Quando se examina o percentual de dietas inadequadas, as proporções podem ser consideradas elevadas para ambos os sexos. No entanto, vale registrar que os testes visando identificar a associação entre as variáveis não se revelaram estatisticamente significativos.

Tabela 14. Distribuição dos escolares de acordo com a participação dos macronutrientes na dieta e estratos de idade (em anos). Piedade SP, 2000.

\begin{tabular}{|c|c|c|c|c|c|c|c|c|}
\hline \multirow{3}{*}{$\begin{array}{c}\text { Participação dos } \\
\text { macronutrientes na dieta }\end{array}$} & \multirow{2}{*}{\multicolumn{2}{|c|}{ Observações }} & \multicolumn{6}{|c|}{ Estratos de idade (em anos) } \\
\hline & & & \multicolumn{2}{|c|}{$<10$} & \multicolumn{2}{|c|}{$10|-| 15$} & \multicolumn{2}{|c|}{$>15$} \\
\hline & № & $\%$ & № & $\%$ & № & $\%$ & № & $\%$ \\
\hline Adequada & 176 & 34,65 & 66 & 33,85 & 109 & 35,05 & 1 & 50,00 \\
\hline Inadequada & 332 & 65,35 & 129 & 66,15 & 202 & 64,95 & 1 & 50,00 \\
\hline Total & 508 & 100,00 & 195 & $\begin{array}{l}100,00 \\
(38,40) \\
\end{array}$ & 311 & $\begin{array}{l}100,00 \\
(61,20) \\
\end{array}$ & 2 & $\begin{array}{r}100,00 \\
(0,40) \\
\end{array}$ \\
\hline
\end{tabular}

$\chi^{2}=0,29$, com 2 graus de liberdade, não-significativo.

$\chi^{2}(\mathrm{MH})=0,12$, com 1 grau de liberdade, não-significativo.

Nota: os números entre parênteses são os percentuais em relação ao total de alunos observados $(n=508)$.

De acordo com os dados da Tabela 14, verifica-se que a maior proporção $(66,15 \%)$ de alunos com dietas inadequadas é observada quando se considera o grupo com idade inferior a 10 anos.

Quando se considera a faixa de idade intermediária (10 a 15 anos), observa-se que praticamente $65 \%$ dos alunos tiveram suas dietas classificadas como inadequadas. No entanto, não foi possível captar, por meio dos testes adotados, associação estatisticamente significativa entre as variáveis consideradas.

O resultado merece atenção pois as intervenções visando a prevenção de distúrbios nutricionais devem ser implementadas precocemente, isto é, para serem efetivas devem ser adotadas, tendo como alvo prioritário, os grupos de escolares com menor idade. 
As recentes transformações vivenciadas pela sociedade brasileira contribuíram para mudanças, especialmente no tocante aos hábitos alimentares (local de consumo e tipos de alimentos).

Segundo Martins (1998), "as despesas com alimentação fora do lar mais que dobraram. A sua participação no total de despesas com alimentação passou de $16,37 \%$ em $1974 / 75$ para $31,04 \%$ em $1987 / 88$ ".

Análises elaboradas por Monteiro et al (2000) revelaram que houve aumento dos gastos das famílias com a aquisição do pão francês, indicando uma possível substituição do jantar pelo lanche, que tem no pão o seu principal componente. Registra-se também que, geralmente, o pão é consumido acompanhado de embutidos e refrigerantes.

Reconhece-se também que nos últimos anos houve um crescimento substancial do consumo de alimentos industrializados, envolvendo diferentes graus de processamento.

Tendo em vista a escassez de informações e análises sobre a participação dos alimentos industrializados, especialmente no consumo de crianças e jovens moradores de municípios com substancial parcela de habitantes vivendo na zona rural, julgou-se pertinente apresentar, a seguir, os resultados reunidos na Tabela 15.

Tabela 15. Distribuição dos escolares de acordo com estratos de idade e sexo e participação relativa dos alimentos in natura e industrializados na dieta. Piedade - SP, 2000.

\begin{tabular}{|c|c|c|c|c|c|c|}
\hline \multirow{3}{*}{$\begin{array}{l}\text { Participação relativa dos alimentos } \\
\text { (em percentagem) }\end{array}$} & \multicolumn{6}{|c|}{$\begin{array}{l}\text { Estratos de idade (em anos) e sexo dos } \\
\text { escolares }\end{array}$} \\
\hline & \multicolumn{2}{|c|}{$<10$} & \multicolumn{2}{|c|}{$10|-| 12$} & \multicolumn{2}{|c|}{$\geq 13$} \\
\hline & $M$ & $\mathrm{~F}$ & $M$ & $\mathrm{~F}$ & $M$ & $\mathrm{~F}$ \\
\hline in natura & 11,0 & 6,3 & 9,0 & 8,0 & 6,3 & 7,0 \\
\hline industrializados & 89,0 & 93,7 & 81,0 & 92,0 & 93,7 & 93,0 \\
\hline Total & 100,0 & 100,0 & 100,0 & 100,0 & 100,0 & 100,0 \\
\hline
\end{tabular}

Examinando os dados da Tabela 15 verifica-se que há maior participação dos alimentos in natura na dieta dos meninos (11\%) com idade inferior a 10 
anos. Quando se examina os resultados obtidos, analisando o consumo das meninas, a maior proporção de participação de alimentos in natura é encontrada entre o grupo com idade entre 10 e 12 anos.

A maior participação (média) relativa dos alimentos, observada entre os escolares com maior idade ( $\geq 13$ anos) possivelmente decorre da maior autonomia desse grupo para selecionar os alimentos de sua preferência, ou ainda, desfrutarem de maiores possibilidades de consumir alimentos fora do domicílio. Embora não tenha sido observada substancial adesão dos escolaresà alimentação fora de casa, é possível que o hábito se concentre entre os escolares mais com maior idade.

Uma das hipóteses para o baixo consumo de alimentos in natura em geral, talvez seja a substancial parcela de mães que trabalham fora do domicílio. Embora pesquisa desenvolvida por Sasaki et al. (2001), realizada em Piedade, tenha mostrado que $90,4 \%$ das mães de 120 alunos (amostra) assumiam o preparo das refeições de seus filhos, é possível que esteja em curso uma tendência de simplificação do preparo das refeições, especialmente dos pratos que envolvem hortaliças, comumente consumidas cozidas.

Barretto \& Cyrillo (2001), analisaram, adotando a base de dados das pesquisas de orçamentos familiares (1990-1996), os percentuais dos gastos domiciliares com três grupos de alimentos: in natura, industrializados com menor grau de processamento (denominado pelos autores como semielaborados) e industrializados com maior grau de processamento. Os autores verificaram um aumento na proporção dos gastos domiciliares com alimentos industrializados de maior grau de processamento e tendência inversa para os menos processados. Os autores observaram que os alimentos in natura sofreram importante redução (35\%). Vale salientar que essas mudanças não podem ser explicadas satisfatoriamente pela variação nos preços relativos. Os autores inferiram que para se elevar o consumo de produtos in natura, o aumento da renda seria um incentivo econômico mais adequado que a redução dos preços relativos, principalmente pelo fato das classes de renda mais 
elevadas apresentarem um gasto maior com os alimentos in natura. As análises apontam para a existência de uma provável inadequação dietética nos domicílios das famílias de São Paulo e de riscos associados a uma ingestão insuficiente de legumes, verduras e frutas.

Como descrito anteriormente, espera-se, como postula a Lei de Engel, que o processo de desenvolvimento econômico-social acarrete uma redução da participação da alimentação no gasto total das famílias. No entanto, sabe-se que em algumas regiões do país, e especificamente para famílias de menor renda, o gasto com a alimentação é ainda o de maior proporção no orçamento familiar (Menezes et al. (2002).

Visando conhecer a proporção de gastos com alimentação registrados pelas famílias dos escolares em relação à renda, utilizou -se a técnica estatística de regressão linear (conforme descrito na seção referente àmetodologia).

A equação de regressão estimada é mostrada a seguir:

$$
\begin{array}{ccc}
=1,358 & -0,193 & \text { LRFPC } \\
(22,37)^{*} & (-14,37)^{\star}
\end{array}
$$

onde = proporção das despesas com alimentação

LRFPC = logaritmo da renda familiar per capita

Note-se que os asteriscos que acompanham os números entre parênteses são os valores do Teste $T$.

Analisando os resultados é possível verificar a existência de correlação positiva entre as variáveis consideradas (proporção de despesas com alimentação e renda familiar) ao nível de significância de $p<0,0001$.

Assim, confirma-se, tendo por base as informações obtidas junto æ̀ famílias dos escolares de Piedade, que conforme ocorre o aumento da renda, diminui o percentual da mesma, destinado a compra de alimentos. 
É importante lembrar que as famílias mais pobres, praticamente comprometem a totalidade de seu orçamento com a aquisição de alimentos para a família.

Também julgou-se oportuno apresentar nesta seção os resultados obtidos, adotando-se também, a técnica da regressão linear, relativos a correlação entre logaritmo da despesa com alimentos e o logaritmo da renda familiar.

A equação de regressão estimada é mostrada a seguir:

$$
\begin{aligned}
& \begin{array}{r}
=2,321 \\
(12,70)^{*} \\
\quad(16,02)^{*}
\end{array} \\
& \text { onde } \quad=\text { logaritmo das despesas com alimentação } \\
& \text { LRFPC = logaritmo da renda familiar per capita }
\end{aligned}
$$

Analisando os resultados é possível verificar a tendência de aumento das despesas com alimentação, conforme há crescimento da renda. Assim, famílias mais ricas conseguem adquirir maior quantidade física de alimentos (ou ainda soma-se a essa quantidade os gastos com alimentação fora do domicílio).

O coeficiente de elasticidade é 0,482 , o que permite concluir que um acréscimo de $10 \%$ na renda familiar condicionará um aumento de 4,8\% nas despesas da família com alimentação.

\subsection{Estilo de vida}

Entre os vários objetivos da pesquisa, julgou-se pertinente conhecer o estilo de vida dos escolares da rede pública de Piedade. Nesta seção da dissertação, pretende-se tecer considerações sobre o tema, além de apresentar os principais resultados obtidos. 
Conforme descrito anteriormente, buscou-se conhecer, entre outros hábitos, o tempo dedicado pelos escolares à programação televisiva. Entre os 508 escolares integrantes da pesquisa, 466 (91,7\%) revelaram que assistem rotineiramente à televisão, permanecendo expostos à programação diária, em média, por 3,3 horas.

Estudo elaborado por Silva \& Malina (2000), considerou o hábito de assistir televisão, como um recurso de lazer considerado de baixo custo para as famílias de menor poder aquisitivo, e ainda, identificou o referido hábito como um dos fatores condicionantes, entre adolescentes, do sedentarismo. De acordo com os referidos autores, $85 \%$ dos meninos foram classificados como sedentários, enquanto entre as meninas, a proporção se revelou muito superior (94\%). A média de horas dedicadas aos programas de televisão pelos meninos e meninas foi de 4,4 e 4,9 horas/dia, respectivamente.

Ao analisar o estilo de vida de 95 adolescentes, Priore (1996) verificou que $81 \%$ assistiam à televisão, com tempo mediano de exposição entre 3 e 4 horas por dia. O autor observou também que $15,6 \%$ dos adolescentes passavam mais de 6 horas por dia envolvidos com a programação da TV.

Pesquisa de Castro (2001) tendo por base informações de 36 estudantes moradores da zona rural e 46 alunos da zona urbana, com idade entre 13 e 17 anos, do município de Garça - SP, revelou que todos os alunos da zona urbana assistiam à TV. Para os alunos da zona rural, o autor encontrou percentual de 97,2 . Quando os alunos foram distribuídos, segundo o tempo (horas) dedicadas à televisão, pra ticamente $50 \%$ dos alunos da zona urbana assistiam mais de 4 horas por dia de TV, enquanto um número menor (15 alunos), residentes na zona rural, exibiam o mesmo costume.

Tendo como referências os dados obtidos por vários autores, apresentados nesta seção, fica evidente que os alunos da rede pública de ensino de Piedade revelaram comportamento que pode ser definido como "mais saudável", especialmente no que se refere as horas dedicadas àtelevisão. 
Destaca-se, também, que $78,8 \%(n=268)$ informaram que praticam esporte rotineiramente. Trata-se portanto de um resultado muito favorável, pois aliado à baixa permanência de exposição à programação televisiva, pode ser um indicativo de opção por estilo de vida mais saudável, na medida que não contribui para o sedentarismo.

Hanley et al. (2000) verificaram tendo por base amostra de 242 adolescentes, com idade entre 10 e 19 anos, que os indivíduos que geralmente assistiam à TV, no mínimo durante 5 horas por dia (incluindo vídeos e vídeo game) exibiam 2,5 vezes mais risco de sobrepeso quando comparado com os adolescentes que assistiam no máximo 2 horas por dia de TV. Os referidos autores alertam para o risco associado ao referido comportamento que poderá se manifestar por meio de vários mecanismos, incluindo a redução do tempo gasto em atividades de maior intensidade, redução na taxa metabólica e o consumo mais freqüente de snacks.

De acordo com Gambardella (1995), o aumento do consumo de alimentos pode ser decorrente do hábito de ingeri-los em frente àtelevisão ou por exemplo utilizando o computador. O tempo gasto assistindo à televisão pode contribuir consideravelmente, de acordo com o autor, para o sedentarismo e desbalanço energético.

Cintra et al. (2001) destacaram que as crianças brasileiras estão se tornando cada vez mais sedentárias, permanecendo muito tempo assistindo os programas da TV e o que é pior, freqüentemente consumindo alimentos com elevado conteúdo energético.

Analisando dados relativos a 578 escolares da rede pública de ensino, Caroba (2002) verificou que $82,7 \%$ dos alunos tinham o hábito de consumir alimentos enquanto assistiam programas de televisão. Observou, também, que em média a exposição diária era de 4 horas. No entanto, por meio de análises, o referido autor não encontrou associação estatisticamente significativa entre o estado nutricional e o tempo de exposição àtelevisão. 
É interessante registrar que Coon et al (2001) identificaram hábitos alimentares mais saudáveis em integrantes de famílias cuja exposição à TV ocorreu separadamente da prática alimentar. Os autores destacaram que alimentos como pizza, lanches e refrigerantes foram consumidos em menor quantidade, enquanto o consumo de frutas e hortaliças revelou-se mais elevado. Tal situação se revelou contrária à observada entre as famílias que costumavam se alimentar enquanto assistiam televisão.

Tendo por base a presente pesquisa, envolvendo amostra de escolares de Piedade, no que se refere ao consumo de alimentos fora do domicílio, foi possível verificar, de acordo com informações fornecidas pelos pais dos escolares, que o costume de consumir alimentos fora de casa alcança 35,1\% dos escolares. Registra-se, também, que as opções costumavam comer fora de casa uma vez por semana, sendo que os locais preferidas, para consumo de alimentos, de acordo com as citações dos pais foram: casa de parentes $(76,7 \%)$, lanchonetes $(18,6 \%)$, bares $(7,7 \%)$ e vendedores ambulantes $(2,3 \%)$. Os resultados apontam para um baixo consumo de alimentos fora do domicílio. Vale lembrar que nesta pesquisa foi elaborada análise pormenorizada envolvendo as variáveis estado nutricional e consumo de alimentos fora do domicílio, apresentadas anteriormente (seção 4.1).

Dos 401 alunos de Piedade para os quais havia informação disponível, foi possível observar que o preparo das refeições era realizado predominantemente pelas mães $(71 \%)$, seguido pelas avós $(6 \%)$ e apenas $2 \%$ das crianças preparavam as próprias refeições.

Castro (2001) registrou em sua pesquisa, envolvendo estudantes da zona rural e urbana de município paulista, que a maioria dos alunos não realizam suas refeições fora de casa $(56,5 \%$ de escolares residentes na zona urbana e $94,4 \%$ de escolares residentes na zona rural). Vale destacar que a proporção de alunos que informaram que consomem suas refeições na casa de parentes alcança $37 \%$, quando se considera os moradores da zona urbana, e $5,6 \%$, dos residentes na zona rural. Em relação ao preparo das refeições, o referido autor 
também verificou que a tarefa é assumida, na maioria das vezes, pelas mães (59,8\%). Um número menor de refeições $(2,2 \%)$ é preparada pelas avós e 3,7\% dos alunos preparam suas próprias refeições.

Segundo Vieira et al. (2001) as mudanças nas práticas alimentares nos últimos anos têm sido caracterizadas pelo crescente aumento do número de refeições feitas fora do lar, com o concomitante aumento da participação no mercado das refeições "prontas" ou "semi-prontas" para consumo, indicando uma tendência ascendente para a procura pelos "alimentos de conveniência".

Visando complementar as informações relativas ao consumo alimentar, realizado fora do domicílio, foram elaboradas análises, tendo por base as informações fornecidas pelos escolares, no tocante à adesão ao programa de merenda escolar.

Foi possível observar que 99,6\% $(n=504)$ dos alunos informaram que nas escolas, integrantes da amostra, a merenda é fornecida diariamente. Especificamente quanto à adesão ao programa de merenda escolar - PME, é interessante destacar que $73,9 \%(n=374)$ dos alunos costumam consumir as refeições gratuitas distribuídas nas unidades de ensino. Trata-se de resultado surpreendente, tendo em vista a descrição relativa àadesão, elaborada por Silva (1998).

Segundo 0 referido autor, entre os escolares com menor renda ( $\leq$ $\mathrm{R} \$ 400,00$ ), $40 \%$ consumiam as refeições ( 4 ou 5 vezes por semana) distribuídas nas escolas. A proporção alcança 12,5\% quando se considera o grupo de alunos pertencentes æ̀s famílias com rendimento pelo menos igual ou superior a $\mathrm{R} \$ 1600,00$.

Vale registrar, também, os resultados obtidos por Sturion (2002) que analisando a adesão ao PME, em dez municípios brasileiros verificou que o consumo da merenda é fortemente influenciado pelas variáveis socioeconômicas (estratos de menor renda e ainda, possuírem pais com menor nível de escolaridade) a idade e sexo dos alunos. De acordo com o autor, nos municípios que integram a amostra, $56,5 \%$ dos alunos consumiam a merenda diariamente. 


\section{CONCLUSÕES}

A análise do estado nutricional revelou proporção de $22,1 \%$ de escolares com indicativo de baixo peso (IMC $<15^{\circ} \mathrm{P}$ ), enquanto apenas $10 \%$ foram classificados com IMC $\geq 85^{\circ} \mathrm{P}$ (indicativo de sobrepeso), proporção considerada inferior àesperada.

Não foi possível, nesta pesquisa, por meio da adoção de análises estatísticas, verificar associação entre o estado nutricional e a renda familiar per capita.

Observou-se também associação positiva entre o estado nutricional (adotando a distribuição dos percentis de IMC) e a situação do trabalho da mãe fora do domicílio. A maior proporção de alunos com indicativo de baixo peso é encontrada quando se considera o grupo de mães que trabalham fora do domicílio. É provável que tal situação reflita a menor disponibilidade de tempo da mãe para o preparo e acompanhamento das refeições de seus filhos e, conseqüentemente, no estímulo para adoção de dietas saudáveis, pelos escolares. Além disso, é importante considerar que possivelmente as mães que trabalham fora do domicílio são aquelas que revelam menor escolaridade e também menores rendimentos.

Em relação à distribuição do consumo de energia e nutrientes, merece destaque a baixa ingestão, observada em substancial parcela da amostra de alunos, de energia, fibras, folacina, vitamina $C$, vitamina $A$, vitamina $E$, cálcio, ferro e zinco. Por outro lado, merece destaque o consumo, acima do preconizado, de proteínas, vitamina $B_{12}$ e selênio. 
As análises do consumo, tendo por base a participação dos macronutrientes no valor energético total da dieta, revelam que pequena proporção, ou seja, aproximadamente $35 \%$ dos meninos e $34 \%$ das meninas apresentaram dietas classificadas como adequadas.

Quanto æ̀̀ análises de consumo de alimentos, adotando-se como parâmetro a pirâmide alimentar adaptada à população brasileira, os resultados são muito semelhantes quando se considera os escolares pertencentes aos dois grupos de sexos. Em especial, quando se observa o grupo intitulado: óleos, gorduras, açúcares e doces, verifica-se que a participação do mesmo ocorreu de forma substancial no total de alimentos consumidos, superando, por exemplo, a participação do grupo das hortaliças e frutas.

Observou-se que praticamente a totalidade dos escolares $(91,7 \%)$ permanecem expostos àprogramação televisiva, em média, por 3,3 horas.

Foi observado que $35,1 \%$ dos escolares costumam consumir alimentos fora do domicílio. No entanto, quando se considerou o local, ampla maioria $(76,7 \%)$ registrou que consome os alimentos na casa de parentes e apenas 18,6\% o fazem, optando por estabelecimentos do tipo lanchonete.

$\mathrm{Na}$ presente pesquisa, foi possível verificar forte correlação entre a proporção de gastos com alimentação e a renda familiar dos escolares, ou seja, quanto menor a renda familiar, maior foi o percentual comprometido com a aquisição de alimentos.

Entre as diversas intervenções possíveis de serem adotadas, a curto prazo, destaca-se a orientação dos escolares e respectivas famílias para que, na medida do possível, possam incorporar práticas alimentares que contribuam para uma vida saudável. 


\section{ANEXOS}


ANEXO A - Questionário aplicado aos escolares.

\section{CNPq/ESALQ/USP}

Pesquisa: "Padrão alimentar e estado nutricional: caracterização de escolares de município paulista"

Nome da Escola:

1- Localização da Escola: （ ) Central （）Periférica （）Rural

2- Nome do Aluno: Série que freqüenta:

2.1- Sexo:

( )Masculino

( ) Feminino

2.2- Data de Nascimento:

$\overline{\text { (Dia) }}^{\prime} \overline{\text { (Mês) }}^{\prime} \frac{}{\text { (Ano) }}$

3- Na sua escola a merenda é servida todos os dias?

( ) Sim

( ) Não

( ) Não sabe

4- Se na escola não é servida a merenda todos os dias, quantas vezes você observa que é servida?

( ) 1 vez por semana

( ) 3 vezes por semana

( ) 2 vezes por semana

( ) 4 vezes por semana

5- Você costuma comer a merenda da escola?

( ) $\operatorname{Sim}$ ( ) Não 
6- Se você falou que come a merenda da escola, informe quantas vezes isso ocorre na semana:

( ) 1 dia por semana

( ) 2 dias por semana

( ) 3 dias por semana

( ) 4 dias por semana

( ) 5 dias por semana ( = todos os dias)

7- Por quê você não come a merenda da escola?

( ) Traz lanche de casa

( ) Compra lanche na cantina

( ) Não tem vontade ou fome

( ) Não gosta

( ) Não dá tempo

( ) Tem nojo

( ) Prefere brincar

( ) Compra alimentos de vendedores ambulantes

\begin{tabular}{|c|c|}
\hline ) Sim & ( \\
\hline ) Sim & ( \\
\hline ) Sim & \\
\hline ) $\mathrm{Sim}$ & \\
\hline ) $\mathrm{Sim}$ & \\
\hline ) $\mathrm{Sim}$ & \\
\hline ) $\mathrm{Sim}$ & \\
\hline ) Sim & \\
\hline
\end{tabular}

8- Fale os 5 alimentos ou preparações (tipo: pratos completos) que você mais gosta de comer na merenda escolar:

9- Fale os 5 alimentos ou preparações (tipo: pratos completos) que você menos gosta de comer na merenda escolar:

10- Cite as 5 verduras / hortaliças que você mais gosta de comer:

11- Qual(is) a(s) forma(s) que você prefere que as verduras (que você citou na questão anterior) sejam preparadas? 
12- Na merenda da sua escola é (são) servida(s) verdura(s)?

( ) Sim

( ) Não

( ) Não sabe

13- Costuma comprar alimentos na cantina da escola?

( ) A escola não tem cantina $\quad(\quad) \operatorname{Sim} \quad$ Não

14- Como nesta escola não tem cantina, você compra alimentos de vendedores que permanecem próximo da escola ou bares/lanchonetes?

( ) Sim ( ) Não

15- Quantas vezes por semana você compra os alimentos dos vendedores de rua?

( ) 1 vez por semana

( ) 2 vezes por semana

( ) 3 vezes por semana

( ) 4 vezes por semana

( ) 5 vezes por semana (= todos os dias)

16- Qual(is) alimento(s) você compra, dos vendedores de rua, com mais freqüência?

17- Se você costuma comprar alimentos na cantina, fale quantas vezes por semana:

( ) 1 vez por semana

( ) 2 vezes por semana

( ) 3 vezes por semana

( ) 4 vezes por semana

( 5 vezes por semana (= todos os dias) 
18- Qual(is) alimento(s) você compra na cantina?

( ) Salgados (tipo caseiro)

( ) Salgadinhos (tipo "chips")

( ) Refrigerantes

( ) Doces/Guloseimas (balas, chicletes, pirulitos)

( ) Chocolates

( ) Sorvete

( ) Bolachas

( ) Amendoim

( ) Pipoca

( ) Bolos

( ) Frutas

( ) Sanduíches

( ) Sucos

( ) Leite

( ) Cachorro-quente

\begin{tabular}{|c|c|}
\hline ) Sim & ( \\
\hline ) Sim & ( \\
\hline ) Sim & ( \\
\hline ) Sim & ( \\
\hline ) $\operatorname{Sim}$ & ( \\
\hline ) Sim & ( \\
\hline ) $\mathrm{Sim}$ & ( \\
\hline ) Sim & ( \\
\hline ) $\mathrm{Sim}$ & ( \\
\hline ) $\mathrm{Sim}$ & ( \\
\hline ) $\mathrm{Sim}$ & ( \\
\hline ) Sim & ( \\
\hline ) $\mathrm{Sim}$ & 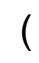 \\
\hline ) Sim & 1 \\
\hline ) $\mathrm{Sim}$ & \\
\hline
\end{tabular}

19- Você acredita que os alimentos vendidos na cantina são melhores para sua saúde do que as refeições da merenda escolar?

( ) $\operatorname{Sim}$

( ) Não

( ) Não sabe

20- Você assiste os programas de televisão?

( ) Sim

( ) Não

21- Como a resposta foi positiva (assiste televisão) quanto tempo por dia você passa assistindo àTV?

22- Dos comerciais de televisão que falam sobre alimentos, fale os três que você mais gosta: 
23- Marque com um $(X)$ a freqüência que você consome os alimentos, apresentados abaixo:

\begin{tabular}{|c|c|c|c|c|}
\hline Alimento & Todo dia & $\begin{array}{l}2 x \text { por } \\
\text { semana }\end{array}$ & $\begin{array}{l}1 \times \text { por } \\
\text { mês }\end{array}$ & Nunca \\
\hline Arroz & & & & \\
\hline Macarrão & & & & \\
\hline Pão & & & & \\
\hline Feijão & & & & \\
\hline Carnes (porco, frango, boi) & & & & \\
\hline Vísceras (fígado, língua, rim, etc.) & & & & \\
\hline Leite e derivados & & & & \\
\hline Achocolatados & & & & \\
\hline Embutidos (salame, salsicha, mortadela, etc & & & & \\
\hline Verduras (Ex.: alface, etc.) & & & & \\
\hline Frutas & & & & \\
\hline Sucos de frutas & & & & \\
\hline Refrigerantes & & & & \\
\hline Doces (caseiro e/ou industrializado) & & & & \\
\hline Chocolates & & & & \\
\hline Sorvetes & & & & \\
\hline Outros. Quais? & & & & \\
\hline
\end{tabular}




\section{RECORDATÓRIO DE 24 HORAS}

Nome do Aluno:

Escola:

Série que freqüenta:

\begin{tabular}{|c|c|c|c|}
\hline Refeição & $\begin{array}{l}\text { Horário e local } \\
\text { da refeição }\end{array}$ & Alimentos & $\begin{array}{l}\text { Quantidade de alimentos } \\
\text { (em medidas caseiras) }\end{array}$ \\
\hline Café da manhã & & & \\
\hline $\begin{array}{l}\text { Lanche ou Merend } \\
\text { da manhã* }\end{array}$ & & & \\
\hline Almoço & & & \\
\hline $\begin{array}{l}\text { Lanche ou Merend } \\
\qquad \text { da tarde* }\end{array}$ & & & \\
\hline Jantar & & & \\
\hline Lanche noturno & & & \\
\hline
\end{tabular}

*Informar se a refeição é a merenda oferecida na escola. 
ANEXO B - Questionário aplicado aos pais dos escolares.

\section{CNPq/ESALQ/USP}

Pesquisa: "Padrão alimentar e estado nutricional: caracterização de escolares de município paulista"

\section{IDENTIFICAÇÃO DA FAMÍLIA E DAS CONDIÇÕES DE VIDA DO ESCOLAR}

1- Nome da Escola do seu filho:

2- Nome do Aluno:

2.1- Série que o seu filho freqüenta:

2.2- Sexo:

( )Masculino

( ) Feminino

2.3- Informe a data de nascimento do seu filho :

$$
\overline{\text { (Dia) }}^{\prime} \overline{\text { (Mês) }}^{\prime} \frac{}{\text { (Ano) }}
$$

3- Assinale o tipo de casa em que o(a) senhor(a) vive com os filhos:

( ) Alvenaria (tijolos) ( ) Não alvenaria (madeira, lata, etc.)

4- Marcar o tipo de água utilizada dentro da casa:

( ) Rede geral ( ) Poço ou nascente ( ) Outra forma

5- Marque o tipo de esgoto que a casa onde vive sua família tem:

( ) Rede geral ( ) A casa não é ligada àrede de esgoto 
6- Marque com um $(X)$ os equipamentos que existem na sua casa:

( ) Rádio

( ) Geladeira

( ) Televisão

( ) Filtro de água

7- Informe o número de pessoas (adultos e crianças) que vivem na casa:

Número de adultos (com 14 anos ou mais):

Número de crianças (com menos de 14 anos):

\section{8- O pai ou padrasto mora com o escolar?}

( ) Sim

( ) Não

9- O pai ou padrasto do escolar trabalha:

( ) Sim ( ) Não

Escreva quanto o pai ou padrasto ganhou no mês passado (junte a renda do trabalho, pensão, aposentadoria ou outras rendas): $\mathrm{R} \$$

10- Se a mãe ou madrasta mora com o escolar, escreva:

Idade da mãe: anos

Até que série a mãe ou madrasta estudou (Marque apenas uma resposta):

( ) $1^{\circ}$ grau completo

( ) $2^{\circ}$ grau completo

( ) Curso superior completo

A mãe ou madrasta do escolar trabalha?

Escreva quanto a mãe ou madrasta ganhou no mês passado (junte, se existir, a renda do trabalho, pensão, aposentadoria ou outras rendas): $\mathrm{R} \$$

11- Escreva o valor total da renda familiar (a renda familiar e a soma de todos os ganhos - por exemplo, pensão, salários, aluguéis, etc.) do último mês: $\mathrm{R} \$$ 
12- Marque com um (X) se algum membro da sua família está inscrito em algum programa de donativos ou similares:

( ) Sim

( ) Não

13- Seu filho freqüentou creche (quando tinha entre zero a cinco anos) no passado?

( ) Sim

( ) Não

14- Caso o(a) senhor(a) respondeu que sim, preencha os trechos abaixo com os dados da criança que freqüentou a creche:

A criança entrou na creche com meses e saiu com meses.

15- Quem prepara as refeições para seu filho?

( ) Mãe

( ) Pai

( ) Própria criança

( ) Compra pronto

( ) Empregada

( ) Avó

( ) Outro. Quem prepara?

$\begin{array}{lll}(\quad) \operatorname{Sim} & (\text { ) Não } \\ (\quad) \operatorname{Sim} & (\text { ) Não } \\ (\quad) \operatorname{Sim} & (\text { ) Não } \\ (\quad) \operatorname{Sim} & (\quad) \text { Não } \\ (\quad) \operatorname{Sim} & (\quad) \text { Não } \\ (\quad) \operatorname{Sim} & (\quad) \text { Não } \\ (\quad) \operatorname{Sim} & (\quad) \text { Não }\end{array}$

16- Quantos Reais (R\$) o(a) senhor(a) gastou no último mês com a compra de alimentos?

$\mathrm{R} \$$

17- O seu filho costuma comer fora de casa? (Não considere a merenda que ele recebe na escola)

( ) Sim ( ) Não

18- Se o(a) senhor(a) respondeu que seu filho costuma consumir alimentos fora de casa, marque o número de vezes:

( ) Uma vez por semana

( ) Quatro vezes por semana

( ) Duas a três vezes por semana

( ) Todos os dias 
19- Em caso afirmativo, marque o(s) local(is) onde seu filho costuma consumir alimentos ou refeições:

( ) Lanchonetes

( ) Bares

( ) Sim ( ) Não

, Bares

( ) Sim

( ) Não

( ) Ambulantes (carrinhos que vendem comida na rua)

) Sim ( ) Não

( ) Casa de parentes

( ) Sim ( ) Não

20- Marque as refeições que seu filho faz em casa:

( ) Café da manhã

( ) Merenda ou lanche da manhã

( ) Almoço

( ) Merenda ou lanche da tarde

( ) Jantar

\begin{tabular}{|c|c|}
\hline ) Sim & ( \\
\hline ) Sim & \\
\hline ) Sim & \\
\hline ) Sim & \\
\hline ) Sim & ( \\
\hline
\end{tabular}

21- $O$ que o(a) senhor(a) faz quando seu filho pede para comprar algum alimento que ele viu nos comerciais da televisão? (Assinale uma única alternativa)

( ) Não compra

( ) Às vezes (eventualmente) compra

( ) Compra quando tem dinheiro

( ) Sempre compra

( ) Não pede

22- Na sua opinião, o que deveria conter uma alimentação adequada para o crescimento de seu filho? Assinale um ou mais itens:

( ) Proteínas

( ) Sim ( ) Não

( ) Calorias

( ) Sim ( ) Não

( ) Gorduras

( ) Sim ( ) Não

( ) Vitaminas

( ) Sim ( ) Não

( ) Minerais

( ) Sim ( ) Não

( ) Fibras

( ) Sim ( ) Não

( ) Não sei

( ) Sim ( ) Não 
23- Considerando o costume alimentar da sua família, escreva quais os alimentos (cite no máximo 5 alimentos) que são mais apreciados:

24- Informe quais alimentos são menos apreciados por sua família (cite no máximo 5 alimentos):

25- Marque quais são as fontes de informações utilizadas para escolher os alimentos que são comprados para sua família:

( ) Televisão

$\begin{array}{lll}(\quad) \operatorname{Sim} & (\text { ) Não } \\ (\quad) \operatorname{Sim} & (\text { ) Não } \\ (\quad) \operatorname{Sim} & (\quad) \text { Não } \\ (\quad) \operatorname{Sim} & (\quad) \text { Não } \\ (\quad) \operatorname{Sim} & (\quad) \text { Não }\end{array}$

26- $O(a)$ senhor(a) sabe quais alimentos a escola distribui para o seu filho?

( ) Sim

( ) Não

27- Quando seu filho vai para a escola, o(a) senhor(a) nota alguma mudança no jeito dele em relação à comida?

( ) Sim

( ) Não

( ) Não observo

28- Se o(a) senhor(a) respondeu que o jeito do seu filho muda, marque o tipo de mudança:

( ) Consome menor quantidade de alimentos em casa

( ) Deixou de tomar alguma refeição em casa

( ) Conheceu novos alimentos/pratos e passou a solicitar para tê-los em casa também

29- Seu filho trabalha ou ajuda em alguma atividade em casa ou fora de casa?

( ) Sim

( ) Não 
30- Se respondeu sim na questão anterior, escreva qual é o tipo de trabalho e quantas horas por dia seu filho trabalha:

Tipo de trabalho:

Horas de trabalho por dia:

Com remuneração:

( ) Sim ( ) Não

Em caso afirmativo, quanto ele recebeu no último mês? $\mathrm{R} \$$ 
Anexo C - Medidas Caseiras
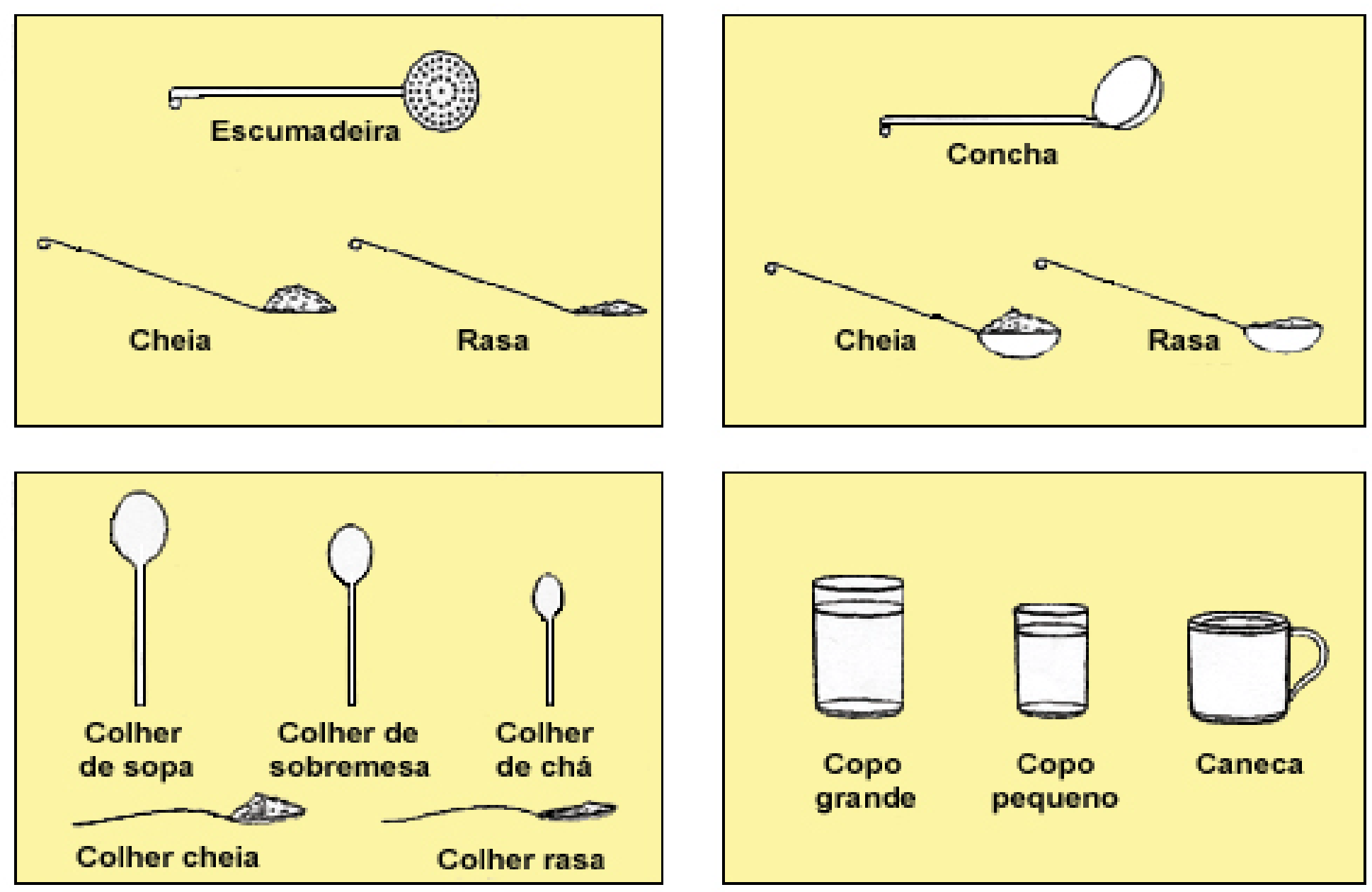


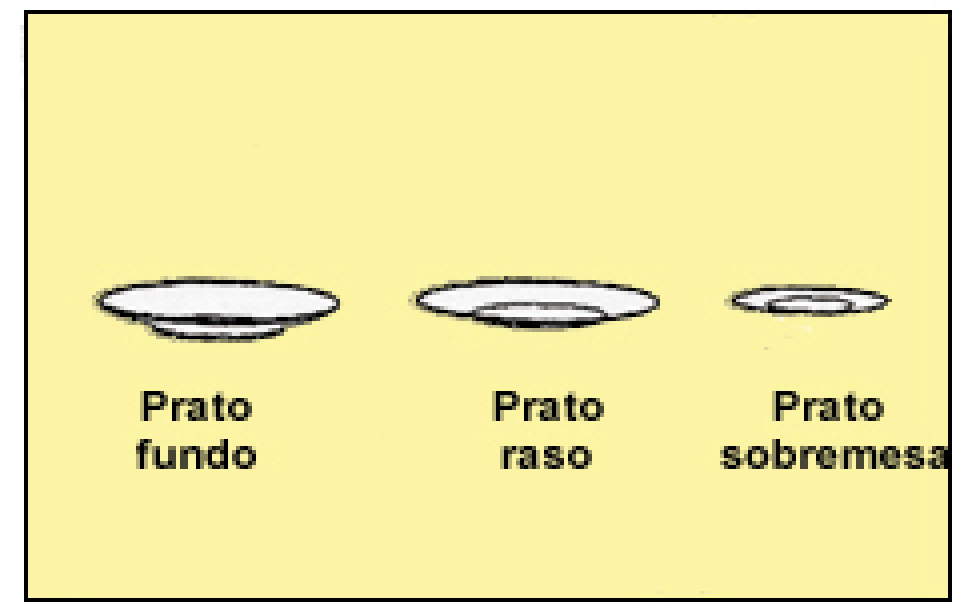

Pedaços de carne em prato raso

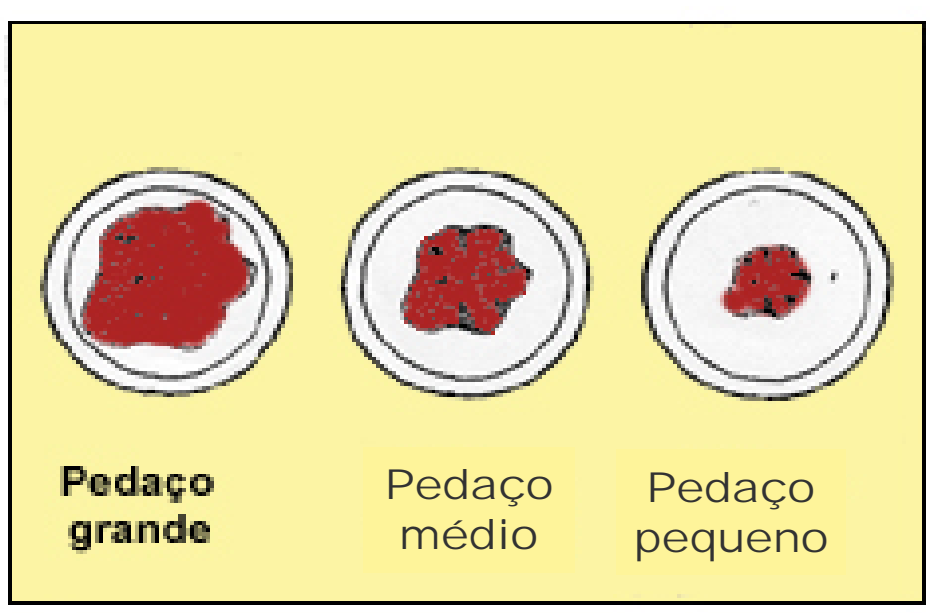

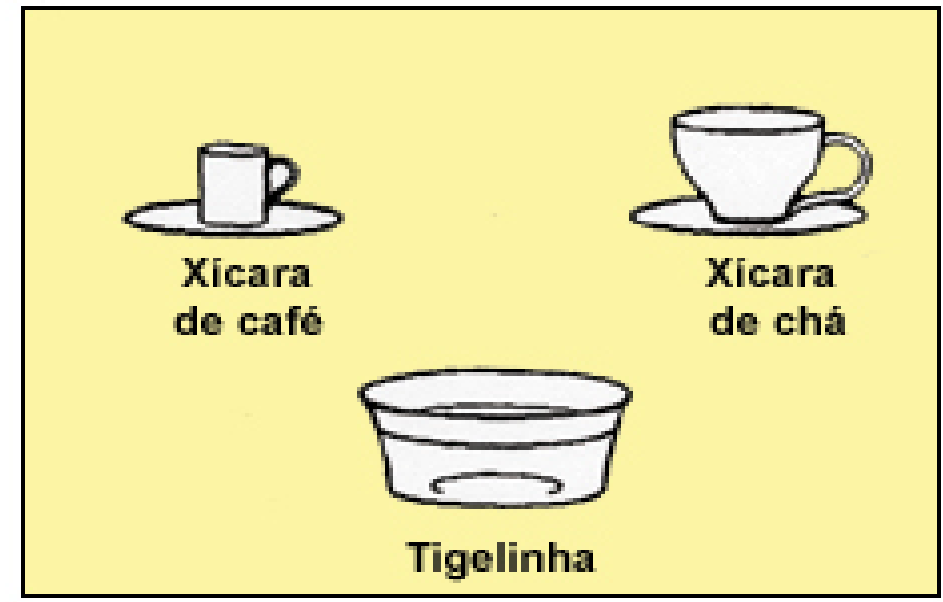

Pedaços de bolo ou doce em prato de sobremesa

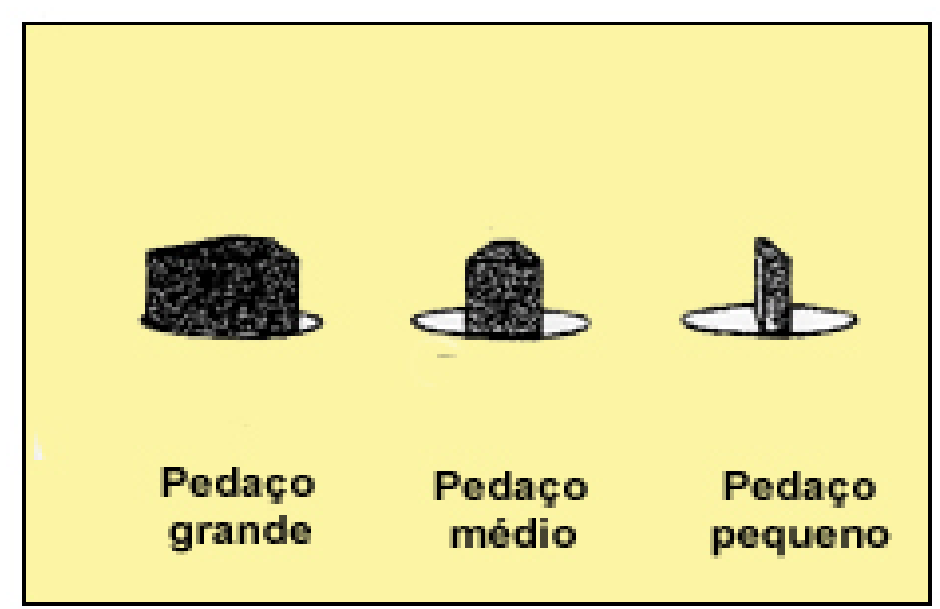




\section{REFERÊNCIAS BIBLIOGRÁFICAS}

ALBANO, R.D. Estado nutricional e consumo alimentar de adolescentes. São Paulo, 2000. 70p. Dissertação (Mestrado) - Faculdade de Saúde Pública, Universidade de São Paulo.

AMIGO, H.; LEONE, C.; BUSTOS, P.; GALLO, P. Comparación de la situación nutricional en escolares de bajo nivel socioeconómico de Santiago (Chile) y São Paulo (Brasil). Archivos Latinoamericanos de Nutricion, v.45, n.1, p.31-35, 1995.

ANDERSON, J.J.B. The status of adolescent nutrition. Nutrition Today, v.26, n.2, p.7-10, 1991.

ANDRADE, T. de M. Estudo psicológico de crianças e adolescentes. In: FISBERG, M. Obesidade na infância e adolescência. São Paulo: BYK, 1995. cap.13, p.100-104.

ANGELIS, R.C. de. Digestão de alimentos. In: ANGELIS, R.C. de. Fome oculta. São Paulo: Atheneu, 2000. cap.3, p.14-20a.

ANGELIS, R.C. de. Hábitos alimentares no Brasil. In: ANGELIS, R.C. de. Fome oculta. São Paulo: Atheneu, 2000. cap.35, p.188-191b. 
ANGELIS, R.C. de. Nutrientes não-energéticos. In: ANGELIS, R.C. de. Fome oculta. São Paulo: Atheneu, 2000. cap.4, p.21-27c.

ANJOS, L.A. Índice de massa corporal (massa corporal.estatura ${ }^{2}$ ) como indicador do estado nutricional de adultos: revisão da literatura. Revista de Saúde Pública, v.26, n.6, p.431-436, 1992.

AQUINO, R. de C. de. Alimentos industrializados na dieta das crianças do município de São Paulo. São Paulo, 1999. 102p. Dissertação (Mestrado) Faculdade de Saúde Pública, Universidade de São Paulo.

BARBIERI, D. Micronutrientes em pediatria. In: ANGELIS, R.C. de. Fome oculta. São Paulo: Atheneu, 2000. cap.17, p.88-93.

BARRETTO, S.A.J.; CYRILLO, D.C. Análise da composição dos gastos com alimentação no município de São Paulo (Brasil) na década de 1990. Revista de Saúde Pública, v.35, n.1, p.52-59, 2001.

BERNARD, L.; LAVALLÉE, C.; GRAY-DONALD, K.; DELISLE, H. Overweight in Cree schoolchildren and adolescents associated with diet, low physical activity, and high television viewing. Journal of the American Dietetic Association, v.95, n.7, p.800-802, July 1995.

BLEIL, S.I. O padrão alimentar ocidental: considerações sobre a mudança de hábitos no Brasil. Cadernos de Debate, v.6, p.1-25, 1998.

BOCCIA, S. Jantar em família. Veja, v.33, n.15, p.83, 2000. 
BORRA, S.T.; SCHWARTZ, NE.; SPAIN, C.G.; NATCHIPOLSKY, M.M. Food, physical activity, and fun: Inspiring America's kids to more healthful lifestyles. Journal of the American Dietetic Association, v.95, n.7, p.816-818, July 1995.

BRASIL. Ministério da Saúde. Consolidação das normas e padrões de alimentos. Decreto-Lei nf 986, de 21 de out. de 1969. In: ASSOCIAÇÃO BRASILEIRA DAS INDÚSTRIAS DE ALIMENTAÇÀO. Compêndio da legislação de alimentos. São Paulo: ABIA, 2001. v.1.

CAROBA, D.C.R. A escola e o consumo alimentar de adolescentes matriculados na rede pública de ensino. Piracicaba, 2002. 162p. Dissertação (Mestrado) - Escola Superior de Agricultura "Luiz de Queiroz", Universidade de São Paulo.

CAROBA, D.C.R.; SILVA, M.V. da.; PIPITONE, M.A.P.; STURION, G.L. Alimentos industrializados: uma análise da sua participação na dieta de escolares da rede pública de ensino. In: CONGRESSO BRASILEIRO DE CIÊNCIA E TECNOLOGIA DE ALIMENTOS, 17., Fortaleza, 2000. Resumos. Fortaleza: SBCTA, 2000. p.7.7.

CARVALHO, C.M.R.G. de; NOGUEIRA, A.M.T.; TELES, J.B.M.; PAZ, S.M.R. da; SOUSA, R.M.L. de. Consumo alimentar de adolescentes matriculados em um colégio particular de Teresina, Piauí, Brasil. Revista de Nutrição, v.14, n.2, p.85-93, maio/ago. 2001.

CASOTTI, L.; RIBEIRO, A.; SANTOS, C.; RIBEIRO, P. Consumo de alimentos e nutrição: dificuldades práticas e teóricas. Cadernos de Debate, v.6, p.2639, 1998. 
CASTRO, F.A.F. de; PEREIRA, C.A. dos S.; PRIORE, S.E.; RIBEIRO, S.M.R.; BITTENCOURT, M.C.B.; QUEIROZ, V.M.V. de. Educação nutricional: a importância da prática dietética. Nutrição em Pauta, v.10, n.52, p.9-15, 2002.

CASTRO, M.P. de S. Hábitos alimentares de estudantes brasileiros das zonas urbanas e rural: um estudo de Garça - São Paulo. São Paulo, 2001. 95p. Dissertação (Mestrado) - Faculdade de Saúde Pública, Universidade de São Paulo.

CASTRO, P.F.; MAGALHÃES, L.C.G. Recebimento e dispêndio das famílias brasileiras: evidências recentes da Pesquisa de Orçamentos Familiares (POF) - 1995/1996: IPEA, 1998. 37p. (Texto para discussão, 614)

CAVADINI, C. Dietary habits in adolescence: contribution of snacking. In: BALLABRIGA, A. Feeding from toddlers to adolescence. Philadelphia: Lippincott-Raven Publishers, 1996. cap.7, p.117-129. (Nestlé Nutrition Workshop Series, 37)

CINTRA, I. de P.; OLIVEIRA, C.L. de.; FISBERG, M. Obesidade: tratamento e prevenção. Nutrição em Pauta, v.9, n.50, p.10-17, set./out. 2001.

COITINHO, D.C.; LEÃO, M.M. Condições nutricionais da população brasileira: adultos e idosos. Brasília: PNSN, 1991. 57p.

COLLI, A.S; DELUQUI, C.G. Adolescência. In: ALCÂNTARA, P. de; MARCONDES, E. Pediatria básica. São Paulo: Sarvier, 1978. cap.2, p.175-189. 
COON, K.A.; GOLDBERG, J.; ROGERS, B. et al. Relationships between use of television during meals and children's food consumption patterns. Pediatrics, v.107, n.1, p.7, 2001.

CORSO, A.C.T. Crescimento de escolares em áreas carentes do município de Florianópolis/SC: um estudo caso-controle. São Paulo, 1996. 121p. Tese (Doutorado) - Faculdade de Saúde Pública, Universidade de São Paulo.

CROSS, A.T.; BABICZ, D.; CUSHMAN, L.F. Snacking patterns among 1,800 adults and children. Journal of the American Dietetic Association, v.94, n.12, p.1398-1403, 1994.

DEAN, A.G.; ARNER, T.G.; SANGAM, S. et al. Epi Info 2000: a database and statistics program for public health professionals for use on Windows 95, 98, NT and 2000 computers (software). Atlanta: Centers for Disease Control and Prevention, 2000.

DOYLE, E.I.; FELDMAN, R.H.L. Factors affecting nutrition behavior among middle-class adolescents in urban area of Northern region of Brazil. Revista de Saúde Pública, v.31, n.4, p.342-350, ago. 1997.

ESCRIVÃO, M.A.M.S.; LOPEZ, F.A. Prognóstico da obesidade na infância e na adolescência. In: Obesidade na infância e adolescência. São Paulo: BYK, 1995. cap.18, p.146-148.

FIGUEIREDO, C.A.; NOVA, E.M.V.; RIBEIRO, H.G.; CABRAL, M.G. A criança, a alimentação e a escola. Revista Portuguesa de Nutrição, v.6, n.2, p.552, maio/ago. 1994. 
FONSECA, V.M.; SICHIERI, R; VEIGA, G.V. Fatores associados à obesidade em adolescentes. Revista de Saúde Pública, v.32, n.6, p.541-549, 1998.

FRENCH, S.A.; ERRY, C.L.; LEON, G.R.; FULKERSON, J.A. Food preferences, eating patterns, and physical activity among adolescents: correlates of eating disorders symptoms. Journal of Adolescent Health, v.15, p.286-294, 1994.

FUNDAÇÃO INSTITUTO BRASILEIRO DE GEOGRAFIA E ESTATÍSTICA FIBGE; FUNDO DAS NAÇÕES UNIDAS PARA A INFÂNCIA - UNICEF. Municípios brasileiros: crianças e suas condições de sobrevivência. Brasília, 1994. 248p.

GAMBA, E.M.; BARROS JÚNIOR, A.A. de B. A utilização do índice de massa corporal na avaliação da obesidade na infância: vantagens e limitações. Revista Paulista de Pediatria, v.17, n.4, p.181-189, dez. 1999.

GAMBARDELLA, A.M.D. Adolescentes, estudantes de período noturno: como se alimentam e gastam suas energias. São Paulo, 1995. 81p. Tese (Doutorado) - Faculdade de Saúde Pública, Universidade de São Paulo.

GAMBARDELLA, A.M.D.; FRUTUOSO, M.F.P.; FRANCHI, C. Prática alimentar de adolescentes. Revista de Nutrição, v.12, n.1, p.55-63, jan./abr. 1999.

GARCIA, A.E.B.; BLISKA, F.M.M.; LEITE, R.S.S.F. Tendências nas exportações brasileiras de alimentos industrializados: dos semi-elaborados aos elaborados. Ciência e Tecnologia de Alimentos, v.14, n.2, p.129-148, jul./dez. 1994. 
GIOVANNINI, M.; AGOSTINI, C.; BELLÙ, R.; RIVA, E. Fiber in childhood nutrition. In: BALLABRIGA, A. Feeding from toddlers to adolescence. Philadelphia: Lippincott-Raven Publishers, 1996. cap.9, p.143-154. (Nestlé Nutrition Workshop Series, 37)

GITTELSOHN, J.; WOLEVER, T.M.S.; HARRIS, S.B.; HARRIS-GIRALDO, R.; HANLEY, A.J.G.; ZINMAN, B. Specific patterns of food consumption and preparation are associated with diabetes and obesity in a Native Canadian community. The Journal of Nutrition, v.128, n.3, p.541-547, Mar. 1998.

GRAZINI, J.T. Analogia entre comerciais de alimentos e hábito alimentar de adolescentes. São Paulo, 1996. 68p. Dissertação (Mestrado) - Escola Paulista de Medicina, Universidade Federal de São Paulo.

GUESRY, P.R. The nutritional role of soft drinks during childhood and adolescence. In: BALLABRIGA, A. Feeding from toddlers to adolescence. Philadelphia: Lippincott-Raven Publishers, 1996. cap.11, p.169-185. (Nestlé Nutrition Workshop Series, 37)

HANLEY, A.J.G.; BARRIS, S.B.; GITTELSOHN, J.; WOLEVER, T.M.S.; SAKSVIG, B.; ZINMAN, B. Overweight among children and adolescents in a native canadian community: prevalence and associated factors. American Journal of Clinical Nutrition, v.71, n.3, p.693-700, Mar. 2000.

HASCHKE, F.; MALE, C. Trace elements in children and adolescents. In: BALLABRIGA, A. Feeding from toddlers to adolescence. Philadelphia: Lippincott-Raven Publishers, 1996. cap.4, p.45-62. (Nestlé Nutrition Workshop Series, 37) 
INSTITUTO BRASILEIRO DE GEOGRAFIA E ESTATÍSTICA. Censo 2000. http://www.bge.gov.br (06 maio 2002)

JELLIFFE, D.B. Evaluacion del estado de nutricion de la comunidad. Ginebra: Organizacion Mundial de la Salud, 1968. 291p. (Série de Monografias, 53)

JOHNSON, R.K.; GUTHRIE, H.; SMICIKLAS-WRIGHT, H.; WANG, M.Q. Characterizing nutrient intakes of children by sociodemographic factors. Public Health Reports, v.109, n.3, p.414-420, May/June 1994.

JUZWIAK, C.R. DRIs: Um novo conceito de recomendações nutricionais. Nutrição, Saúde \& Performance, v.2, n.8, p.7-9, nov./dez. 2000.

KAZAPI, I.M.; DI PIETRO, P.F.; AVANCINI, S.R.P. et al. Consumo de energia e macronutrientes por adolescentes de escolas públicas e privadas. Revista de Nutrição, v.14, p.27-33, 2001. Suplemento.

LERNER, B.R. A alimentação e a anemia carencial em adolescentes. São Paulo, 1994. 112p. Tese (Doutorado) - Faculdade de Saúde Pública, Universidade de São Paulo.

LERNER, B.R.; LEI, D.L.M.; CHAVES, S.P.; FREIRE, R.D. O cálcio consumido por adolescentes de escolas públicas de Osasco, São Paulo. Revista de Nutrição, v.13, n.1, p.57-63, jan./abr. 2000.

LINHARES, J. Fome de quê? Comer para viver. Folha de São Paulo. Folhateen, São Paulo, 20 ago. 2001. p.6-7. 
MAHAN, L.K.; ARLIN, M.T. Krause: alimentos, nutrição e dietoterapia. 8.ed. São Paulo: Roca, 1994. 957p.

MANTEL, N.; HAENSZEL, W. Statistical aspects of analysis of data from retrospective studies of disease. Journal of the National Cancer Institute, v.22, p.719-748, 1959.

MARTINS, E. Variações no consumo de alimentos no Brasil de 1974/75 a 1987/88. Piracicaba, 1998. 117p. Dissertação (Mestrado) - Escola Superior de Agricultura “Luiz de Queiroz”, Universidade de São Paulo.

MARTINS FILHO, J.M. Os diferentes hábitos alimentares de crianças e jovens. Nutrição, Saúde \& Performance, v.3, n.10, p.31, 2001.

MENEZES, T.; SILVEIRA, F.G.; MAGALHÃES, L.C.G. et al. Gastos alimentares nas grandes regiões urbanas do Brasil: aplicação no modelo AID aos murodados da POF 1995/1996.

IBGE. Brasília: IPEA, jul. 2002 (Texto para discussão, 896)

MONDINI, L.; MONTEIRO, C.A. Mudanças no padrão de alimentação. In: MONTEIRO, C.A. (Org.). Velhos e novos males da saúde no Brasil. São Paulo: Hucitec, 1995. cap.4, p.79-89.

MONTEIRO, C.A.; CONDE, W.L. Tendência secular da desnutrição e da obesidade na infância na cidade de São Paulo (1974-1996). Revista de Saúde Pública, v.34, n.6, p.52-61, dez. 2000. 
MONTEIRO, C.A.; MONDINI,L.; COSTA, R.B.L. Mudanças na composição e adequação nutricional da dieta familiar nas áreas metropolitanas do Brasil (1988-1996). Revista de Saúde Pública, v.34, n.3, p.251-258, 2000.

MONTEIRO, C.A.; MONDINI, L.; SOUZA, A.M. de; POPKIN, B.M. Da desnutrição para a obesidade: a transição nutricional no Brasil. In: MONTEIRO, C.A. (Org.). Velhos e novos males da saúde no Brasil. São Paulo: Hucitec, 1995. cap.14, p.247-255.

MORGAN, K.J.; ZABIK, M.E.; LEVEILLE, G.A. The role of breakfast in nutrient intake of 5-to 12-year-old children. American Journal of Clinical Nutrition, v.34, p.1418-1427, 1981.

MÓRON, C. Opciones y desafios para a seguridad alimentaria de America Latina y el Caribe. Roma: FAO, 1996. Documento para la Cumbre Mundial de la Alimentacion.

MOURA, E.C. de.; SONATI, J.G. Perfil lipídico de dietas e sua relação com os níveis de colesterolemia em escolares de uma escola pública de Campinas, São Paulo (Brasil). Revista de Nutrição, v.11, n.1, p.69-75, jan./jun. 1998.

NATIONAL ACADEMY OF SCIENCES. Institute of Medicine. Food and Nutrition Board. Dietary reference intakes: applications in dietary assessment. Washington: National Academy Press, 2000. 306p. http://www.nap.edu (21 Mar. 2002)

NATIONAL ACADEMY OF SCIENCES. Institute of Medicine. Food and Nutrition Board. Dietary reference intakes for energy, carbohydrates, fiber, fat, protein and amino acids (macronutrients). Washington: National Academy Press, 2002. 936p. http://www.nap.edu (11 Oct. 2002) 
NATIONAL CENTER FOR HEALTH STATISTICS. Center for Disease Control and Prevention. Growth charts. http://www.cdc.gov (10 June 2002)

NATIONAL RESEARCH COUNCIL. National Academy of Sciences. Food and Nutrition Board. Recommended dietary allowances. 10.ed. Washington: National Academy Press, 1989. 284p.

NEUMARK-SZTAINER, D.; STORY, M.; PERRY, C.; CASEY, M.A. Factors influencing food choices of adolescents: findings from focus-group discussions with adolescents. Journal of the American Dietetic Association, v.99, n.8, p.929-934, Aug. 1999.

NUZZO, L. Avaliação do estado nutricional de adolescentes de uma instituição particular de ensino. São Paulo, 1998. 69p. Dissertação (Mestrado) Faculdade de Saúde Pública, Universidade de São Paulo.

OETTERER, M. (Coord.); SILVA, M.V. da; OMETTO, A.M.H.; PIPITONE, M.A.P.; FURTUOSO, M.C.O.; STURION, G.L. Avaliação do programa de alimentação escolar. Piracicaba: ESALQ, Depto. de Agroindústria, Alimentos e Nutrição/FNDCT, 1999. 365p. (Relatório de Pesquisa)

OLIVEIRA, J.E.D. de; CUNHA, S.F.C. da; MARCHINI, J.S. A desnutrição dos pobres e ricos: dados sobre a alimentação no Brasil. São Paulo: Sarvier, 1996. 123p.

ORTEGA, R.M.; REQUEJO, A.M.; ANDRÉS, P. et al. Relationship between diet composition and body mass index in a group of spanish adolescents. British Journal of Nutrition, v.74, p.765-773, 1995. 
PHILIPPI, S.T.; COLUCCI, A.C.A.; CRUZ, A.R.; FERREIRA, M.N.; COUTINHO, R.L.R. Alimentação saudável na infância e na adolescência. In: SILVA, M.N. da (Org.); PIPITONE, M.A.P.; STURION, G.L.; PHILIPPI, S.T. Curso de atualização em alimentação e nutrição para professores da rede pública de ensino. Piracicaba: ESALQ, Depto. de Agroindústria, Alimentos e Nutrição/FAPESP, 2000. cap.2, p.46-60.

PHILIPPI, S.T.; FISBERG, R.; LATTERZA, A.R.; CRUZ, A.T.R.; MANTOANELLI, G.; COLUCCI, A.C.A. Avaliação de rótulos e embalagens de alimentos infantis: bebida láctea, iogurte e queijo tipo "petit suisse". Higiene Alimentar, v.13, n.60, p.21-28, mar. 1999a.

PHILIPPI, S.T. Guia alimentar para o ano 2000. In: ANGELIS, R.C. de. Fome Oculta. São Paulo: Atheneu, 2000. cap.32, p.160-176.

PHILIPPI, S.T.; LATTERZA, A.R.; CRUZ, A.T.R.; RIBEIRO, L.C. Pirâmide alimentar adaptada: guia para escolha dos alimentos. Revista de Nutrição, v.12, n.1, p.65-80, 1999b.

PHILIPPI, S.T.; SZARFARC, S.C.; LATTERZA, A.R. Virtual Nutri (software). Versão 1.0 for windows. São Paulo: Universidade de São Paulo, Faculdade de Saúde Pública, Depto. de Nutrição, 1996.

POMERANZ, L. A demanda de produtos alimentícios industrializados no Brasil. Revista de Administração de Empresas, v.17, n.6, p.81-101, nov./dez. 1977.

PRIORE, S.E. Perfil nutricional de adolescentes do sexo masculino residentes em favelas. São Carlos: UFSCar, 1996. 133p. 
RUFFO, P. Nutrição na adolescência. O Mundo da Saúde, v.21, n.2, p.86-89, 1997.

RUIZ, S. Dá-lhe ferro nos irritados e nos sonolentos. Folha de São Paulo, São Paulo, 16 mar. 1998. p.5.

SANTANA, A.C. de. Mudanças recentes nas relações de demanda de carne no Brasil. Revista de Economia e Sociologia Rural, v.37, n.2, p.51-76, abr./jun. 1999.

SASAKI, F.F.; MAESTRO, V.; SANCHES, M.; SILVA, M.V.da. Análise das preferências de escolares, da rede pública de ensino, por hortaliças minimamente processadas. In: SIMPÓSIO INTERNACIONAL DE INICIAÇÃO CIENTÍFICA DA USP - SIICUSP, 9., Piracicaba, 2001. Resumos. São Paulo: USP, 2001. p.6.3.

SAS INSTITUTE. The SAS System (software). Version 8. Cary, 1998.

SAWAYA, A.L. Transição: desnutrição energético-protéica e obesidade. In: SAWAYA, A.L. (Org.); FERRAR, A.A.; UGNEBU, C.H.; SOLYMOS, G.M.B.; VIEIRA, M. de F.A.; SOUZA, M.H. do N. Desnutrição urbana no Brasil em um período de transição. São Paulo: Cortez, 1997. cap.2, p.35-61.

SCHWARTZMAN, F.; TEIXEIRA, A.C. Educação nutricional prevenindo a obesidade. Nutrição em Pauta, v.6, n.32, p.30-32, set./out. 1998.

SICHIERI, R. Consumo de nutrientes. In: SICHIERI, R. Epidemiologia da obesidade. Rio de Janeiro: UERJ, 1998. cap.6, p.88-106. 
SICHIERI, R.; MATHIAS, T.; MOURA, A.S. Stunting, high weight-for-height, anemia and dietary intake among brazilian students from a rural community. Nutrition Research, v.16, n.2, p.201-209, 1996.

SILVA, A.C.Q.R.; REGO, A.I.A. Adolescente: necessidades dietéticas e perigos para cardiopatias. Nutrição em Pauta, v.8, n.43, p.52-56, 2000.

SILVA, M.V. da. Consumo de alimentos, programas de suplementação e estado nutricional de escolares. In: SILVA, M.V. da. (Org.); PIPITONE, M.A.P.; STURION, G.L.; PHILIPPI, S.T. Curso de atualização em alimentação e nutrição para professores da rede pública de ensino. Piracicaba: ESALQ, Depto. de Agroindústria, Alimentos e Nutrição/FAPESP, 2000. cap.1, p.1-45.

SILVA, M.V. da. Estado nutricional de escolares matriculados em centros integrados de educação pública - CIEP'S. São Paulo, 1996. 109p. Tese (Doutorado) - Faculdade de Saúde Pública, Universidade de São Paulo.

SILVA, M.V. da; OLIVEIRA, M.A.P. de; FERRATORE, V.A.; TEREZANI, O.L. Estado nutricional de alunos das escolas estaduais de $1^{\circ}$ e $2^{\circ}$ graus do município de Piracicaba, Estado de São Paulo. Piracicaba: ESALQ, Depto. de Agroindústria, Alimentos e Nutrição/UNIMEP/Prefeitura Municipal de Piracicaba, 1999. 39p. (Relatório de Antropometria Nutricional)

SILVA, M.V. da.; PIPITONE, M.A.P.; STURION, G.L.; CAROBA, D.C.R. Educação e saúde e sua relação com o estado nutricional e práticas alimentares de escolares de $1^{\circ}$ grau. In: CONGRESSO BRASILEIRO DE CIÊNCIA E TECNOLOGIA DE ALIMENTOS, Rio de Janeiro, 1998. Anais. Rio de Janeiro: SBCTA, 1998. p.635-638. 
SILVA, R.C.R. da.; MALINA, R.M. Nível de atividade física em adolescentes do Município de Niterói, Rio de Janeiro, Brasil. Cadernos de Saúde Pública, v.16, n.4, p.1091-1097, out./dez. 2000.

STURION, G.L. Programa de alimentação escolar: avaliação do desempenho em dez municípios brasileiros. Campinas, 2002. 269p. Tese (Doutorado) Faculdade de Engenharia de Alimentos, Universidade Estadual de Campinas.

TADDEI, J.A. de A.C. Epidemiologia da obesidade na infância. In: FISBERG, M. Obesidade na infância e adolescência. São Paulo: BYK, 1995. cap.2, p.14-18.

THOMPSON, F.E.; BYERS, T. Dietary assessment resource manual. Journal of Nutrition, v.124, n.11s, p.2245s-2317s, 1994.

TOJO, R.; LEIS, R.; RECAREY, D.; PAVÓN, P. Dietary habits of preschool and school-aged children: health risks and strategies for intervention. In: BALLABRIGA, A. Feeding from toddlers to adolescence. Philadelphia: Lippincott-Raven, 1996. cap.6, p.93-115. (Nestlé Nutrition Workshop Series, 37)

TROIANO, R.P.; FLEGAL, K.M.; KUCZMARSKI, R.J.; CAMPHELL, S.M.; JOHNSON, C.L. Overweight prevalence and trends for children and adolescents. Archives of Pediatrics \& Adolescent Medicine, v.149, p.1085-1091, 1995.

VALVERDE, V.; DELGADO, H.; FLORES, R.; SIBIRIAN, R.; PALMIERI, M. The school as a data source for food and nutrition surveillance systems in Central America and Panamá. Food Nutrition Bulletin, v.7, n.4, p.32-37, 1985. 
VANNUCCHI, H. (Coord.); MENEZES, E.W. de; CAMPANA, A.O.; LAJOLO, F.M. Aplicações das recomendações nutricionais adaptadas à população brasileira. Ribeirão Preto: SBAN, 1990. 156p. (Cadernos de Nutrição, 2)

VANNUCCHI, H.; FREITAS, M.L.S.; SZARFARC, S.C. Prevalência de anemias nutricionais no Brasil. Cadernos de Nutrição, v.4, p.7-26, 1992.

VASCONCELOS, F. de A.G. de. Avaliação nutricional de coletividades: textos de apoio didático. Florianópolis: UFSC, 1995. 154p.

VIEIRA, V.C.R.; PRIORE, S.E.; SABRY, M.O.D.; FERREIRA, A.L.R.; SAMPAIO, H.A.C.; SILVA, M.G.C. da. Hábitos alimentares e consumo de lanches. Nutrição em Pauta, v.9, n.46, p.14-20, jan./fev. 2001.

WATERLOW, J.C.; BUZINA, R.; KELLER, W.; LANE, J.M.; NICHAMAN, M.Z.; TANNER, J.M. The presentation and use of height and weight data for comparing the nutritional status of groups of children under the age of 10 years. Bulletin World Health Organization, v.55, p.489-498, 1977.

WATT, R.G.; SHEIHAM, A. Dietary patterns and changes in inner city adolescents. Journal of Human Nutrition and Dietetics, v.9, p.451-461, Aug. 1996.

WHYBROW, S.; KIRK, T.R. Nutrient intakes and snacking frequency in female students. Journal of Human Nutrition and Dietetics, v.10, n.1, p.237-244, June 1997.

WITTER, C. Televisão e o adolescente: análise de conteúdo da programação preferida. São Paulo, 1991. 279p. Dissertação (Mestrado) - Faculdade de Saúde Pública, Universidade de São Paulo. 
WOODWARD, D.R.; CUMMING, F.J.; BALL, P.J.; WILLIAMS, H.M.; HORNSBY, H.; BOON, J.A. Does television affect teenagers' food choices? Journal of Human Nutrition and Dietetics, v.10, n.1, p.229-235, 1997.

WORLD HEALTH ORGANIZATION - WHO. Physical status: The use and interpretation of anthropometry. Geneva, 1995. 452p. (Who Technical Report Series, 854)

YUYAMA, L.K.O.; AGUIAR, J.P.L.; MACEDO, S.H.M. et al. Avaliação da alimentação de pré-escolares de Barcelos e Ajuricaba, Estado do Amazonas. Revista do Instituto Adolfo Lutz, v.39, n.1/2, p.27-32, 2000.

ZIWIAM, Z.L.J. Educação nutricional na adolescência. Higiene Alimentar, v.13, n.61, p.85-87, 1999. 